\title{
Care for the elderly : an exploration of perceived needs, demands and service use
}

Citation for published version (APA):

van Bilsen, P. M. A. (2007). Care for the elderly : an exploration of perceived needs, demands and service use. [Doctoral Thesis, Maastricht University]. Universiteit Maastricht. https://doi.org/10.26481/dis.20080131pb

Document status and date:

Published: 01/01/2007

DOI:

$10.26481 /$ dis.20080131pb

Document Version:

Publisher's PDF, also known as Version of record

\section{Please check the document version of this publication:}

- A submitted manuscript is the version of the article upon submission and before peer-review. There can be important differences between the submitted version and the official published version of record.

People interested in the research are advised to contact the author for the final version of the publication, or visit the DOI to the publisher's website.

- The final author version and the galley proof are versions of the publication after peer review.

- The final published version features the final layout of the paper including the volume, issue and page numbers.

Link to publication

\footnotetext{
General rights rights.

- You may freely distribute the URL identifying the publication in the public portal. please follow below link for the End User Agreement:

www.umlib.nl/taverne-license

Take down policy

If you believe that this document breaches copyright please contact us at:

repository@maastrichtuniversity.nl

providing details and we will investigate your claim.
}

Copyright and moral rights for the publications made accessible in the public portal are retained by the authors and/or other copyright owners and it is a condition of accessing publications that users recognise and abide by the legal requirements associated with these

- Users may download and print one copy of any publication from the public portal for the purpose of private study or research.

- You may not further distribute the material or use it for any profit-making activity or commercial gain

If the publication is distributed under the terms of Article $25 \mathrm{fa}$ of the Dutch Copyright Act, indicated by the "Taverne" license above, 
Care for the elderly

An exploration of perceived needs, demands and service use

Pascalle M.A. van Bilsen 


\section{Colophon}

Title: Care for the elderly. An exploration of perceived needs, demands and service use

Pascalle MA van Bilsen, thesis Maastricht University

Cover: Hollandse Hoogte, Ouderen voor seniorenwoningen in aanbouw.

Lay-out: Inge en Hans Duimel

Printed by: Elsevier

(C) Pascalle van Bilsen, Maastricht 2007

ISBN 9789035229693

All rights reserved. No part of this thesis may be reproduced or transmitted in any form or by any means, electronic or mechanical, including photocopying, recording or any information storage or retrieval system, without permission in writing from the author, or, when appropriate, from the publishers of the publications.

The studies in this thesis have been financial supported by the insurance companies VGZ and CZ, Provincial Council of Limburg/Provincial Council of Health and Ministery of Health, Welfare and Sport.

Financial support for printing this thesis has been kindly provided by Elsevier. 


\section{Care for the elderly}

An exploration of perceived needs, demands and service use

\section{PROEFSCHRIFT}

ter verkrijging van de graad van doctor aan de Universiteit Maastricht, op gezag van de de Rector Magnificus, prof. mr. G.P.M.F. Mols,

volgens het besluit van het College van Decanen, in het openbaar te verdedigen op donderdag 31 januari 2008 om 12.00 uur.

door 


\section{PROMOTORES}

Prof. dr. J.P.H. Hamers

Prof. dr. W. Groot

Prof. dr. C. Spreeuwenberg

\section{BEOORDELINGSCOMMISSIE}

Prof. dr. J.M.G.A. Schols (voorzitter)

Prof. dr. G.I.J.M. Kempen

Prof. dr. H. Philipsen

Prof. dr. P. Schnabel (Universiteit Utrecht)

Prof. dr. M.J. Trappenburg (Universiteit Utrecht) 


\section{CONTENTS}

$\begin{array}{lll}\text { Chapter 1. General introduction } & 7\end{array}$

Chapter 2. What care do elderly people ask for? An overview

Chapter 3. Demand of elderly people for residential care: an exploratory study

Chapter 4. The use of community-based social services by elderly 61 people at risk of institutionalization: a survey

Chapter 5. Sheltered housing compared to independent housing 79 in the community

Chapter 6. The use of community-based social services by elderly 99 people at risk of institutionalization: an evaluation

Chapter $7 . \quad$ General discussion

Chapter 8. Summary

Samenvatting

Dankwoord

Curriculum Vitae 



\section{1}

\section{GENERAL INTRODUCTION}


Chapter 1 


\section{BACKGROUND}

Demographic and epidemiological changes over the past few decades have transformed health care needs, making long-term care for the frail elderly a major policy issue, particularly in developed countries [1]. This is not simply a question of a need for good-quality care and access within a context of sustainable systems. Other aspects such as housing, participation in society, sense of purposefulness, social contacts, income and a safe living environment are also essential for elderly people to maintain a good quality of life as the need for care and support increases.

Furthermore, most developed countries are undergoing a change from a supply-driven to a more demand-driven approach to health care. Notions of choice and involvement of elderly people play a prominent role in health planning. In such a demand-driven, client-centred care system, consumers' needs should be the basic principle of underpinning policy initiatives. Consequently, policy makers and caregivers puzzle over the question of how to develop and reorganize the health care system so that it takes these needs of clients into account. As a result, a large-scale research programme has been set up with the aim of examining the nature and extent of clients' needs in order to enable policy makers and caregivers to develop a more demand-oriented care system in which the supply of services is tuned to the needs of clients.

This thesis focuses on the needs of elderly people from a client's perspective in terms of long-term care, housing and additional support. This chapter provides a general introduction to the subject of this thesis. First, several concepts used in this thesis will be explained in more detail. Second, the general aim as well as the research questions will be presented. This chapter will then end with an outline of the thesis.

\section{AGEING}

Among the Dutch population as a whole, about 2.2 million persons - $14 \%$ of the total population - are aged 65 years or older. This number of elderly people is expected to rise to $20 \%$ in 2025 [2]. In comparison to other European countries, this rise in the ageing population in the Netherlands is less pronounced. In Italy and France, for example, the share of the elderly population is expected to be $56 \%$ and $51 \%$ respectively by 2025 [3]. The United States is relatively young by developed-country standards [1].

Although the functional status of the elderly has improved, the increasing size of the older population, advances in health care and longer life expectancies suggest there will be no decline in the number of persons needing care. On the contrary, the ageing of the population means that the number of people with chronic disorders will increase. The sheer expansion of the older population and their greater longevity suggest that at any one time there will be significant numbers in need of some care and assistance. 


\section{DEMAND ORIENTATION AND DEMAND-DRIVEN CARE}

Persistent cost-effectiveness and quality concerns have stimulated the interest of policy makers to come up with long-term health care solutions in which the general concepts of free-market thinking, consumerism, managed care (United States of America), demand-driven care or demand orientation, freedom of choice (The Netherlands) and quality of care improvements (United Kingdom) are of paramount significance [4-11]. These 'demand-driven' approaches aim to build a more responsive and effective integrated care system in combination with a consumer-directed approach to maximize the independence and autonomy of disabled elderly people and, therefore, their perceived quality of life.

Most often, demand-driven approaches are presented as a reaction to a strongly institutional, supply-oriented approach. Roughly speaking, within a supply-driven system the available supply of care is the starting point of health care delivery. In this type of health care system, the government has a very important regulatory role [5]. Supply-side steering proved to be an effective steering model in a socio-economic context characterized by tight financial constraints in combination with equal access and fair division of scarce resources [11]. Its adverse effects have become more and more prominent: a poor fit between demand and health care supply, a limited scope for entrepreneurship, flexibility and innovation, and a lack of transparency. This, in combination with a more demanding consumer due to growing prosperity, higher education, greater assertiveness of citizens and a desire for freedom of choice, has caused a need for a more demand-focused health care system $[4,11]$.

The desire for a demand-focused, tailor-made health care reform in the Netherlands goes back to the 1980s. The Dekker Committee of 1987 proposed a shift in decision making from government to other parties, strengthening the role of insurers and increasing consumers' influence [12]. Essentially, the proposals included a shift in decision-making power from government to the market: deregulation of planning and tariff regulation, competition between insurance agencies and health care providers, greater consumer influence, and the introduction of financial incentives for all parties involved. Although not all the proposals of the Dekker Committee have been implemented, the basic underlying principles of reduced government intervention, increased consumer choice and market competition are still principles accepted as those guiding current health care reform. Basically, there is broad consensus about the desirability and need for demand orientation in health care, assuming that [7]:

- it is feasible and meaningful for (parts of) the health care supply to be determined by the actual demand for care (market competition);

- health care consumers are able to make their own choices in health care use and are highly motivated to do so.

Despite this consensus, the actual design and the development of demand orientation in health care are not without problems. Much has been written about its dilemmas, organizational difficulties, financial consequences and 
feasibility (e.g., [4-7, 11, 13-20]). In contrast, the literature on the clarification of these concepts is quite scarce [14]. Most definitions, however, distinguish between the concepts 'demand orientation' and 'demand-driven' [14, 15, 18]. Altogether, both terms have been defined in various ways ranging from mere client orientation, to actual influence on supply by client-driven demand. Rijckmans et al. (2002/2003) compared the various definitions and concluded that there seemed to be a fundamental difference between the two concepts [14, 21]. Regarding demand orientation, the focus is on the extent to which those who provide services take the needs of clients into account. Basically, demand orientation refers to the mutual effort of clients and the provider that leads to the clients receiving help that fulfil their wishes and expectations and at the same time comply with professional standards. The provider has knowledge about the professional standards and therefore tends to control the content and shape of services. As a result, those supplying the services still guide demand. In the case of demand-driven care, the focus is on freedom of choice, with the client having a final say on the type of care received. Control ultimately rest with users (demand), in other words demand guides supply.

Regardless of the definition chosen, both concepts aim to give individual needs and wishes a more central role. Consequently, any analysis of which services to provide should start with a careful analysis of the needs of the target population. The concept of 'need' and related concepts such as demand for care and service utilization will therefore be explained in more detail.

\section{NEEDS}

The concept of 'need' generally refers to a condition characterized as 'some disturbance in health and well-being'. In other words, need points to a loss, deficiency or shortage [22]. 'Need' can also be defined as a motive for compensating a perceived loss [23]. In this sense, the need for care is a translation of a perceived need into an amount of care or support in order to reimburse a shortage.

Many of the relevant articles concerning needs refer to Bradshaw's Classification [24]. Bradshaw (1972) distinguishes four separate definitions to measure and approach the concept of 'need': normative need, felt need, expressed need and comparative need. Normative need or 'objective need' is what the expert or professional or social scientist defines as need in any given situation. A 'desirable' standard is laid down and is compared with the standard that actually exists. If an individual or group falls short of the desirable standard, then they are identified as being in need. Felt need is equated with want, perceived need or 'subjective need'. The only way to assess the felt need for a service is by asking the population whether they feel they need it. Felt need is by itself an inadequate measure of real need. On the one hand, it is limited by the perceptions of the individual as to whether they know that a service is available, in addition to the reluctance in many situations to confess to a loss of 
independence. On the other hand, felt need can be inflated by individuals who ask for help without really needing it. Expressed need or demand is felt need turned into action. The total need then is defined by those people who demand a service. One does not demand a service unless one feels a need, but on the other hand, it is quite common for felt need not to be expressed as a demand. The measure of comparative need is obtained by studying the characteristics of a population in receipt of a service. If there are people with similar characteristics not in receipt of a service, then they are in need.

Besides the different definitions of 'need', the assessment of needs is a very complex activity because of the following characteristics of needs in general:

- Needs always include a judgement. Based on what experts consider to be what is desirable, standards are developed. Based on what individuals think is 'good quality of care or life', these needs are felt or expressed;

- Needs are very personal and strongly linked with the lives of individuals. Even when two clients with the same disability express their perceived need, there is a very good chance that they will express different needs given their own personal background. People are different, in sickness and in health;

- Needs are changeable. Needs change over time both as a result of developments in knowledge, and changing circumstances or values of society. For instance, people can recover from certain diseases or learn to live with their disabilities;

- Needs are linked with social phenomena, societal problems and the availability of resources. If there are no services people can ask for, they will not or will be less likely to express this need.

In order to examine the perceived of needs for care and services so as to enable policy makers and caregivers to develop more demand-oriented care for elderly people, it was decided to specifically ask elderly people whether they felt they needed care, or additional support. So, this thesis aims to focus on the needs of elderly people from the client's perspective (felt or perceived needs), rather than from the perspective of, for example, professional caregivers, policymakers and insurance companies.

Because of the expected variability and changeability of perceived needs, it is nearly impossible to quantify these needs on behalf of the planning of health care services and additional support. However, information about the nature of perceived needs of elderly people is essential for rethinking the current health care supply and to provide orientation towards a demand-oriented supply of care and services.

\section{RELATIONAL NEEDS, DEMANDS AND SUPPLY}

In order to develop a care supply adjusted to the felt needs for care of elderly people, it is important to know how and when a felt or perceived need results in 
an actual demand for care. In an ideal situation the demand for care and health care services resembles the client's perceived needs. Consequently, this demand for care should be translated into a supply of services fulfilling the perceived needs of clients. Unfortunately, this is not how it works in practice [4, 13, 24-29]. First, clients usually phrase their needs in terms of existing arrangements, which are essentially supply-driven. Lack of information about the health care supply, the provision of services and the conditions of supply hinders clients from making a deliberate choice based on their individual situation. Second, not everyone wants or is capable of expressing a felt need in terms of a clear demand due to the stigma attached to a certain service, to ignorance about the availability of a service, to lack of knowledge about where to ask for help, to costs related to the service wanted or to incompetence in formulating a demand for care. Third, individual, social and cultural circumstances (e.g., presence or absence of a spouse or volunteer aid, housing, depression and social isolation) are also of significance with regard to expressing a demand, as well as the content of this demand. Fourth, a demand for care does not automatically result in equal service use. For instance, the demand for care can be out of sync with the possibilities authorities do offer. People can demand something different from the packages covered by the insurance companies. The authorities not only have to pursue a high standard of health care, but also have to control the costs of the health care system and guarantee equal right of access to health care for everybody in society. Moreover, demand can exceed availability resulting in waiting lists for health care services. This means that not all people actually receive the care they wanted. Furthermore, not all services are equally accessible for everybody because of the high costs related to them, or because of geographical distances or regional policy.

The Netherlands Institute for Care and Welfare (NIZW) has even concluded that the actual use of care and services can be seen as a 'tip of the iceberg' based on a study about future scenarios [30]. Service use has proven to be lower than the expressed demand for care. The demand for care, however, was even less than the perceived need for care. This is because the use of these provisions is less than the demand for them. In turn, the demand for the provisions is smaller than the perceived need for care and assistance, as judged by the health problems that have been experienced or observed in the population.

In sum, the concepts of need, demand and service use are strongly related. In this thesis some of these relationships will be discussed. First, it is questionable whether the demand for residential care resulting in waiting lists for admission to homes for the elderly is an accurate reflection of the perceived need of the elderly for this type of care. Second, the use of social services will be evaluated in relation to the perceived need of elderly for these services, as well as in terms of the barriers that could hinder them from asking for these services (demand) or actual using them (service use). 


\section{CARE FOR THE ELDERLY INVOLVES MORE THAN HEALTH CARE ALONE}

Old age comes with its shortcomings. Full recovery from most functional impairments is often impossible, so elderly people have to rearrange their lives taking into account these functional, mental or cognitive impairments. At the same time, elderly people wish to live as independently as possible, even when they need care and support. As a result, the issues surrounding long-term care for elderly people are broad, involving many spheres of life such as health, social services, housing, transportation and support services.

Thus, in order to examine the perceived needs of elderly people for care and support, they should be asked whether they feel they need support encompassing all domains of living. Consequently, distinctions between longterm care, social services and housing need to be made when describing care for the elderly $[1,31]$. These main pillars of care for the elderly will be described in the next subsections.

\section{Long-term care}

Long-term health care for elderly people generally refers to home care and institutional care. There are differences among countries in the definition of home care [32]. According to the Netherlands Institute of Primary Health Care (NIVEL), whose data were used by Eurostat, home care is restricted to care provided at home by professional home-nursing organizations and home-help services. Home nursing includes services such as needs assessment, hygienic and other personal care, routine technical nursing procedures, more complicated nursing activities, patient education, psychosocial activities and evaluation of care. Home help includes services like housework, hygienic and personal care, moral support and psychosocial support [32].

Institutional care for elderly people refers to health care in nursing homes and homes for the elderly. According to the System of Health Account (SHA) definition, nursing and residential care facilities comprise establishments primarily engaged in providing residential care combined with nursing, supervisory or other types of care as required by residents [32]. Although the distinction between nursing homes and residential care (homes for the elderly) is not always clear, homes for the elderly are institutions providing living conditions for old people who are unable to live independently on their own, but who usually require little more nursing care than what can be given by a visiting nurse [33]. Residents in nursing homes, on the contrary, do require intensive nursing care and 24-hour supervision.

Traditionally, the Netherlands has had one of the world's highest rates of institutionalization for elderly people [31]. Housing shortages after the Second World War and the early introduction of state pensions resulted in an expansion of institutional housing in the 1950s and 1960s. Although living in an institution is no longer considered a desirable situation, care for the elderly in the Netherlands is still highly institutionalized, with 64,000 beds in 338 nursing 
homes and 105,375 housing facilities in 538 homes for the elderly in 2004 [34, 35].

Besides home care and institutional care, Nies (2002) distinguishes so-called 'transmural' services [31]. These 'in-between services' have home care as well as institutional characteristics. Examples of these are day care, respite care and sheltered housing with a distinctive care component.

\section{Social services}

Social services are most often part of community-based home care programmes. These complementary services are intended to support elderly people so they can live at home independently. The precise content of community-based social services varies, but they can be divided into counselling activities (social work, individual and group therapy), provision of information (personal adviser), coordinational assistance (care management), companion services (restaurant facilities, telephone circle and buddy project), socio-cultural activities (e.g., cultural, sportive, creative activities), respite care or sitting service, as well as supplementary services like home library service, meals-on-wheels, administrative support, alarm systems, distance-based health care and transportation) [31, 36-41].

\section{Housing}

The physical features of housing affect the ability of elderly people with limitations to live independently, safely and comfortably. So housing plays a vital role in the lives of elderly people, especially when disabilities occur. Within the continuum of housing for the elderly, a distinction can be made between domiciliary (independent housing), transmural (e.g., sheltered housing with care facilities) and institutional housing (nursing homes, homes for the elderly) [31, 42]. Independent housing refers to housing options in the community like regular housing, adapted/special-design housing, apartment dwellings, or service flats. Home modifications and services can be added to this type of housing. Home modifications (handrails, grab bars, easy-access bathrooms and kitchens), for instance, make it easier and safer to carry out activities such as bathing, cooking and climbing stairs. To anticipate this, more and more often newly constructed homes for seniors are built with basic visitability requirements like zero-step entrance to the home, wide interior doors and at least one bedroom and bath on the main floor.

Sheltered housing refers to an independent, fully adapted living environment with more supportive facilities available in the nearby environment as compared to independent living in regular housing. These facilities have communal rooms for activities and meals, emergency call systems and a doorkeeper. Some sheltered accommodations also provide care facilities. Most often these sheltered accommodations are linked to institutionalized settings.

If elderly people are no longer able to function independently, admission into nursing homes or homes for the elderly (residential homes) can be inevitable. 


\section{ELDERLY PEOPLE AT RISK OF INSTITUTIONALIZATION}

Because of the extensive waiting lists for admission into homes for the elderly and health care innovations that enable elderly people to remain at home independently, the group of elderly people at risk of institutionalization was of special interest in this thesis. These elderly people have made an official application for admission to a home for the elderly or care-on-demand ( 24 hours a day) with so-called assessment agencies $[43,44]$. The task of these agencies is to assess the needs of individual clients and determine the amount of care and kinds of services needed. Based on this needs assessment procedure, the need assessor official recommends admission into a home for the elderly or care-ondemand 24 hours a day.

In the Netherlands 33,029 elderly persons were waiting for admission into a home for the elderly in November 2002 [45]. Within one year the number of elderly people waiting for admission decreased to 27,844 [46]. This decrease is mainly a result of an extra health care budget to increase available capacity in intramural care and improvements of the failing registration procedures. Unfortunately, no recent information about waiting lists for homes for the elderly is available. Although the Health Care Insurance Board $(2005,2007)$ did reported on the waiting lists for intramural care, it did not distinguish between elderly people waiting for admission to a nursing home or elders waiting for admission to a home for the elderly $[47,48]$. Waiting lists in the intramural care sector are still a current problem. Waiting lists are a clear signal that demand or expressed need for residential care exceeds availability. These waiting lists place a great burden on the health care system because elderly people who really need residential care are not receiving the care they want and are entitled to. Moreover, these lists contrast with those elderly people who increasingly want and demand a more varied provision of health care services at home so they can age in their familiar home environment as long as possible. Therefore, policy makers and researchers argue that waiting lists for admission into homes for the elderly possibly do not adequately reflect elderly people's perceived need and, as a result, do not adequately reflect the services the elderly prefer. Consequently, this raises the question what services should be offered in order to meet the perceived need for health care of elderly people at risk of institutionalization: community-based long-term care and support, sheltered accommodations, or care in an institutional setting such as homes for the elderly?

\section{GENERAL AIM AND RESEARCH QUESTIONS}

In order to contribute to more demand-oriented care and support for elderly people, three studies have been conducted. The general aim of these studies is to explore the perceived needs of elderly people for care and support. Consequently, elderly people, and especially those who were at risk of institutionalization, were asked what support they needed, including long-term care, social services and housing. Apart from an overview of various needs, the 
basic need of elderly people to live independently and to be in control as long as possible has been contrasted to the actual demand for residential care (homes for the elderly). Furthermore, the use of social services as part of communitybased long-term care has been evaluated. These services have been set up to support elderly people in remaining in their own homes and environment as long as possible. The question is whether elderly people have a perceived need for such services and actually do use them. Finally, the importance of housing for elderly people at risk of institutionalization has been studied as an alternative to ageing in regular housing. The main research questions posed in this thesis are, therefore, fourfold:

\section{What are the perceived needs of elderly people for care and support?}

This question concerns, on the one hand, a definitional challenge in order to get a grip on the concept of need from a client's perspective. On the other hand, this question is intended to result in a list of the perceived needs of a research population of elderly people.

2. Are waiting lists for admission into a home for the elderly an accurate reflection of the perceived need for services of elderly people in later life?

The demand for residential care will be compared to the perceived need for this type of care of elderly people who are already on a waiting list for a home for the elderly. In addition, the determinants associated with the demand for homes for the elderly (waiting lists) will be studied.

3. To what extent are community-based social services being used by those elderly people at risk of institutionalization who prefer to remain independently in the community?

The use of social services by elderly people at risk of institutionalization will be evaluated as an indication of their perceived need for community-based social services. These services are intended to support people in their activities of daily living so they are able to function independently at home or delay admittance to institutionalized settings. In order to detect an increase in service use over time, measurements will take place at two moments in time: at baseline and one year later.

4. Do elderly people living in sheltered accommodation differ in terms of personal characteristics, functional status, well-being, and care and service use, from those living independently in the community, considering the fact that both groups are at risk of institutionalization? 
Sheltered housing claims to offer a secure and social living environment in which frail elderly people with functional impairments can remain independent and receive care when needed. As a result, special attention will be paid to the importance of housing for elderly people at risk of institutionalization. Elderly people at risk of institutionalization will be studied in two living situations: living in sheltered housing and living independently in the community.

\section{OUTLINE OF THE THESIS}

This thesis comprises of seven chapters in which three studies will be described (see Table 1). These studies are mainly exploratory, resulting in an overview of perceived needs of elderly people in general and in a better understanding of the demand for residential care and social service use by elderly people at risk of institutionalization. After a general introduction which provides background information and the outline of the thesis (Chapter 1), Chapter 2 will described the concept of 'perceived need' according to the elderly themselves, and will give an overview of the perceived needs of the elderly for care and support. Chapter 3 describes the second study. This is an exploratory study on the demand of elderly people for homes for the elderly in relation to their perceived need to age in place, outside institutions. Chapters 4, 5 and 6 presents the results of the third study. This study aims to examine the use of social services by elderly people at risk of institutionalization. Special attention will be paid to elderly people at risk of institutionalization living in sheltered accommodations as compared to those elderly at risk living independently in the community (Chapter 5). The thesis concludes in Chapter 7 with a general discussion of the results and methodology of the study, its main conclusions, and its implications for policy, as well as suggesting directions for further research in the field of care for the elderly. 


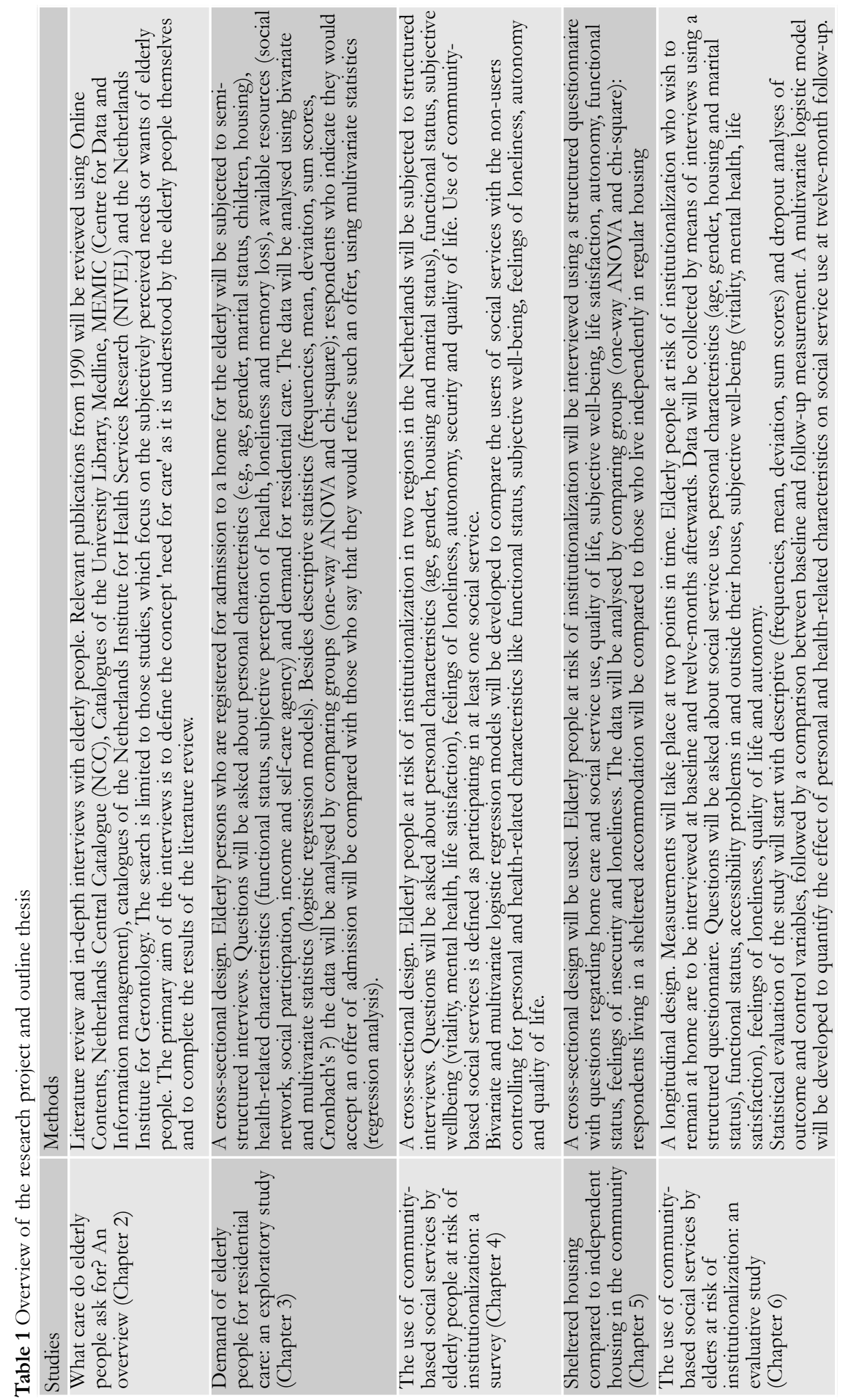




\section{REFERENCES}

1. Brodsky J, Habib J, Hirschfeld M, Siegel B. Care of the frail elderly in developed in developing countries: The experience and the challenges. Aging Clinical and Experimental Research 2002, 14:279-286.

2. Statistics Netherlands. Gezondheid en zorg in cïfers (Health and bealth care in figures 2006). Voorburg/Heerlen, Statistics Netherlands 2006.

3. OECD. Percentage of population aged 65 and over in the European countries. OECD Factbook. Paris, OECD Publications 2005.

4. Ministry of Health, Welfare and Sport. Choosing with Care. The equipping of patients and consumers in a demand driven care sector. International Publication Series Health, Welfare and Sport no 13. The Haque: Ministry of Health, Welfare and Sport (VWS) 2002.

5. Ministry of Health Welfare and Sport. A Question of demand. Outlines of the reform of the health care system in the Netherlands. International Publication Series Health, Welfare and Sport no. 14E 2002.

6. Ministry of Health, Welfare and Sport. Vraag aan bod: hoofdlijnen van vernieuning van het zorgstelsel (Headlines of the current health care reform). The Haque: Ministry of Health, Welfare and Sport (VWS) 2001.

7. Van der Grinten T. Sturing door en sturing van de vraag. Kanttekeningen bij vraagsturing in de gezondheidszorg (Critical remarks on demand-driven health care). In: Vraagsturing \& zorgketens (Vol Ontwikkelingen in de gezondheidszorg, deel 30). Edited by Boon L. Amstelveen: Stichting Sympoz. Platform voor ontwikkelingen in de gezondheidszorg 2000.

8. Leiyu Shi L, Singh D. Delivering Health Care in America: a systematic approach. Gaithersburg, Maryland: Aspen Publishers 1998.

9. Department of Health. The new NHS: modern, dependable. London: HMSO 1997.

10. Council for Public Health and Health Care. De wensen van zorgclienten in Europa (The wants of care consumers in Europe). The Haque: Council for Public Health and Health Care (RVZ) 2003.

11. Council for Public Health and Health Care. De rollen verdeeld (The roles divided). The Haque: Council for Public Health and Health Care (RVZ) 2000.

12. Commissie Dekker. Bereidheid tot verandering (Willingness to change; report of the Committee on Health Care Reform). The Haque: Distributiecentrum Overheidspublicatie 1987.

13. Rijckmans MJN, Garretsen HFL, Van de Goor LAM, Bongers IMB. Key concepts of demand-driven health care; an approach based on client's needs. Medicine and Law 2005, 24: 463-477.

14. Rijckmans M, Garretsen H, Van de Goor I, Bongers I. Demand-orientation and demanddriven care: Conceptual confusion in health care. Eurohealth 2002/2003, 8:33-36.

15. Tonkens E. Mondige burgers, getemde professionals. Marktwerking, vraagsturing en professionaliteit in the publieke sector (Assertive citizen, restrained professionals. Market competition, demand-driven and professionalism in the public sector). Krips, Meppel: Netherlands Institute for Care and Welfare (NIZW) 2003.

16. Terpstra E. Beleidsmatige dilemma's bij de vormgeving van vraaggestuurde zorg (Dilemmas in policy while developing demand-driven health care). In: V raaggestuurde zorg (Demand-driven care). Edited by Boon L. Amstelveen: Stichting SYMPOZ 1997. 
17. Goudriaan G, Vaalburg AM. De vraag als maat. Vraaggerichtheid vanuit gebruikersperspectief (Demand as a starting point. Demand orientation from a clients' perspective). Utrecht: Nederlandse Patiënten/Consumenten Federatie 1998.

18. Council for Public Health and Health Care. Naar een meer vraaggerichte zorg (Towards a more demand-oriented health care system). The Haque: Council for Public Health and Health Care (RVZ) 1998.

19. Council for Public Health and Health Care. Zorgaanbod en clientenperspectief (Care supply and clients' perspective). The Haque: Council for Public Health and Health Care (RVZ) 2003.

20. Trappenburg M. Gezondheidszorg en democratie (Health care and democracy). Rotterdam: Erasmus MC 2005.

21. Rijckmans MJN, Bongers IMB, Garretsen HFL, Van de Goor IAM. A clients' perspective on demand-oriented and demand-driven health care. International Journal of Social Psychiatry 2007, 53.

22. Donabedian MPH. Aspects of Medical Care Administration. Specifying Requirements for Health Care. Cambridge, Massachusetts: Harvard University Press 1973.

23. Orem DE. Nursing; Concepts of Practice. St. Louis: Mosby-Year Book, Inc. 1991.

24. Bradshaw J. A taxonomy of social need. In: Portfolio for health: problems and progress in medical care. Edited by McLachlan G. London: Nuffield Provincial Hospital 1972.

25. Frederiks CMA. Zorgbehoefte van en de zorgverlening aan ouderen. Maastricht: Rijksuniversiteit Limburg 1990.

26. Te Wierik MJM. Verpleeghuisopname. Een onderzoek naar factoren die van invloed zijn op verpleeghuisopname en het verloop daarvan. Maastricht: Rijksuniversiteit Limburg 1991.

27. Ministry of Health Welfare and Sport. Zicht op Zorg. Plan van aanpak Modernisering AWBZ (A perception on care. Policy on the Modernization of the Exceptional Medical Expenses Act). The Haque: Ministry of Health Welfare and Sport (VWS) 1999.

28. Post D, Stokx LJ. Volksgezondheid Toekomst Verkenning 1997. VI. Zorgbehoefte en Zorggebruike (Public health forecast 1997 VI. Health care needs and bealth care use). Maarssen: Elsevier/De Tijdstroom 1997.

29. Timmermans JM, Heide F, de Klerk MMY, Kooiker SE, van Dugteren FA. Vraagverkenning wonen en zorg voor ouderen (An exploration of the demand of elderly people for housing and care). Rijswijk: Social and Cultural Planning Office of the Netherlands (SCP) 1997.

30. Boeije HR, Van Dungen AWL, Pool A, Grypdonck MHF, Van Lieshout PAH. Een verzorgde toekomst. Toekomstscenario's voor verpleging en verzorging (A well-cared-for future). Utrecht: STG/LCVV/NIZW/De Tijdstroom 1997.

31. Nies H. Current and new policies on care for older people. In: Health and health care in the Netherlands A critical self-assessment of Dutch experts in medical and health sciences. Edited by Van Rooij E, Kodner LD, Rijsemus T, Schrijvers G. Maarssen: Elsevier gezondheidszorg 2002.

32. Eurostat. Health Statistics. Key data on health 2002. Luxembourg: Office for Official Publications of the European Communities 2002.

33. Meijer A. Nursing homes in Europe: a comparative study of the organization and financing of nursing homes in five European countries. Wageningen: Wageningen Agricultural University 1998.

34. Statistics Netherlands. Verpleeghuizen (Nursing homes). Retrieved at http://statline.cbs.nl. 
35. Statistics Netherlands. Veryorgingshuizen (Homes for the elderly). Retrieved at http://statline.cbs.nl

36. Greene VL. Do Community-Based Long-Term-Care Services Reduce Nursing Home Use? A Transition Probability Analysis. The Journal of Human Resources 1993, 28:297-317.

37. Cox CB. Community Care for an Aging Society. Issues, Policies and Services. New York: Springer Publishing Company, Inc. 2005.

38. Gaugler JE, Kane RL, Kane RA, Newcomer R. Early Community-Based Service Utilization and Its Effects on Institutionalization in Dementia Caregiving. The Gerontologist 2005, 45:177185.

39. Borgenicht K, Carty E, Feigenbaum LZ. Community Resources for Frail Older Patients. The Western Journal of Medicine 1997, 167:291-294.

40. Plochg T, Klazinga S. Community-based integrated care: myth or must? International Journal for Quality in Health Care 2002, 14:91-101.

41. Duke C. The frail elderly community-based case management project. Geriatric Nursing 2005, 26:122-127.

42. Pynoos J, Nishita CM. Housing. In: The continuum of long-term care. Edited by Evashwick CJ. Long Beach: Thomson Delmar Learning 2005.

43. National Council for Public Health. Indicatiestelling en zorg op maat: advies van de Nationale Raad voor de Volksgezondheid en het College voor Ziekenhuisvoorzieningen (Needs assessments and customized care: recommendations by the National Council for Public Health and the Council for Hospital Facilities). Zoetermeer: National Council for Public Health (RVZ) 1994.

44. Ministry of Health Welfare and Sport. Zorgindicatiebesluit; Besluit van 2 oktober 1997, houdende regels met betrekking tot werkterrein, de samenstelling en werkwijze van indicatieorganen (Care Needs Assessment Decree; White Paper of October, 2, 1997, regulating the activities, formation and mode of operation of Regional Needs Assessment Agencies). Staatsblad van het Koningrijke der Nederlanden 1997, Sdu 447.

45. HHM. Resultaten wachtlijstinventarisatie sector Verpleging en Verzorging; peildatum oktober 2001 (Results of waiting list inventory in Nursing and Care; reference date 2001). Enschede: HHM 2002.

46. HHM. Landelijke rapportage resultaten wachtlijstinventarisatie sector Verpleging en Verzorging; peildatum 1 november 2002 (National report on the existence of waiting lists in Care and Nursing; reference date 1 November 2002). Enschede: Bureau Hoeksma, Homans \& Menting organisatieadviseurs 2003.

47. Ramakers HJ. Rapportage landelijke wachtlijstmeting 1 januari 2005 (National report on the existence of waiting lists, reference date 1 January 2005. Diemen: Health Care Insurance Board (CVZ) 2005.

48. Van Rooij AM, Holwerda B, Koster D: Landelijke wachtlijstrapportage AWBZ: peildatum 1 januari 2007 (National report on waiting lists within the Exceptional Medical Expenses Act: reference date 1 January 2007). Diemen: Health Care Insurance Board (CVZ) 2007. 
General introduction 


\section{2}

WHAT CARE DO ELDERLY PEOPLE ASK FOR? AN OVERVIEW

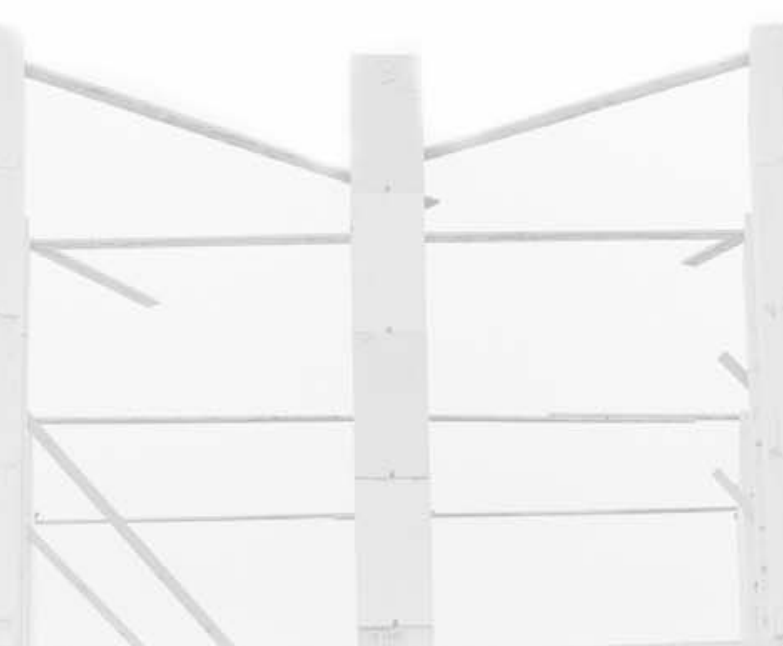

PMA van Bilsen, JPH Hamers, W Groot \& C Spreeuwenberg

Based on a Dutch article published in Tijdschrift voor Gezondheidswetenschappen (Journal of Health Care Sciences) 2004, 82:221-228 


\section{ABSTRACT}

The lack of knowledge concerning the needs of elderly people and the shortage of resources has raised questions about how to care for the growing numbers of elderly in a demand-driven health care system. Therefore, research has been conducted to answer the main question: what are the needs of elderly people regarding health care?

Based on a literature review and in-depth interviews with elderly people living at home or in a nursing home, it can be concluded that elderly people generally experience much the same needs; there is no indication of an endless list of needs. Elderly people make clear that their needs for care go beyond health care alone, and also include needs regarding housing, transport and wellbeing. In addition, it was shown that their needs were dictated by more fundamental human needs, such as the need for autonomy or relatedness with important others. In the end none of the elderly did not ask for any special services, which were not already available. Nevertheless they did comment on the current quality and quantity of services offered.

Based on the results of this research a measurement will be developed that can be used by planners to set out a health care policy. 


\section{INTRODUCTION}

In a demand-driven or, client-centred care system, services have to meet the clients' needs and preferences. Therefore, it should be clear what exactly the clients need and what these needs imply. In addition, the supply of services and care should be varied and flexible so that all of them can be organized in line with the clients' preferences [1]. How can we develop and organize such a demand-driven health care system, which takes the needs of clients into account? Based on a literature review [2] and a study focusing on health care demand, service use and waiting lists of health care organizations [3], it can be concluded that practically no scientific research has been conducted with regard to the nature and extent of needs from a clients' perspective. A large-scale research programme has therefore been set up with the aim of examining the nature and extent of clients' needs to enable policy makers and caregivers to develop a demand-driven care system [4]. This article will report about the first phase of this research programme. The research questions are:

- How do elderly people define the concept 'need for care'?

- What is the perceived need for care and support according to elderly people?

Before answering these questions, we will explain the concept of 'need' and related concepts such as demand for care and service utilization.

\section{Need, demand and service use}

The concept of 'need' generally refers to a condition characterized as 'some disturbance in health and well-being'. In other words, need points to a loss, deficiency or shortage [5]. 'Need' can also be defined as a motive for compensating a perceived loss [6]. In this sense, the need for care is a translation of a perceived need into an amount of care or support to reimburse a shortage [6]. In order to develop a care supply tailored to the needs of care for elderly people, it is important to know how and when a perceived need results in an actual demand for care. In an ideal situation the demand for care and services resembles the clients' perceived needs. Consequently, this demand for care should be translated into a supply of services fulfilling the perceived needs of clients. Unfortunately, this is not how it works in practice [7-9]. First, clients are usually questioned to the 'known direction', which is essentially supply-driven. Second, not everyone is able to express a perceived need in terms of a clear demand for care. Third, individual, social and cultural circumstances are also of paramount significance with regard to expressing a demand as well as the content of the demand. In particular, factors like the availability of a social network or informal care, income and housing are of modifying importance. For instance, the probability that a perceived need results in a demand for care seems more likely for elderly people with a small or fragile social network as compared to elderly people who do have an extensive network. 
Subsequently, a demand for care should be translated into an adequate supply of care and services. This process is mainly determined by so-called assessment agencies [10], established in order to control the growing demand by formalizing and standardizing the process of determining the patients' need for those health services they are entitled to. Based on a person's need for care, but also on available supply, these agencies prescribe adequate care in terms of type, content and amount. As a result, people may not receive the care they have asked for. The Netherlands Institute for Care and Welfare (NIZW) has concluded that the actual use of care and services can be seen as the 'tip of an iceberg' [11] based on a study about future scenarios. Service use has proven to be lower than the expressed demand for care. The demand for care, however, was even less than the perceived need for care. This is because the use of these provisions is lower than the demand for them. In turn, the demand for the provisions is smaller than the need for care and assistance as judged by the health problems that have been experienced or observed in the population.

The relationhip between health care needs, the demand for care and service use is complex. Figure 1 shows the relationship between these concepts [3]. Based on a taxonomy of need described by Bradshaw (1972) [12], a distinction has also been made between objective 'needs' as defined by the expert or professional in any given situation and subjective needs or 'wants' as defined by the population. The expressed need ('demands') has been defined by those people who actually demand a service. It should be noted that Figure 1 does not pretend to give a complete overview of all factors possibly related to the process of need resulting in service use. Given the research questions, 'need' in this study is looked at from a subjective client-centred point of view.

Figure 1 Conceptualizing the concepts of need for care, care demand and service use

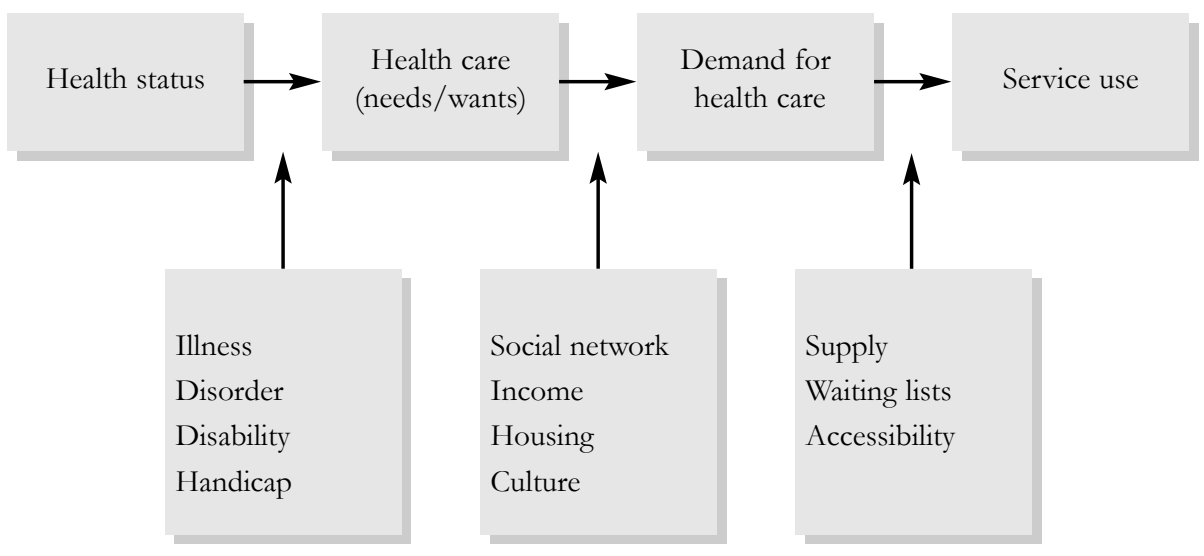




\section{METHODS}

To answer the research questions we conducted a literature review and in-depth interviews with elderly people.

\section{Literature review}

We reviewed relevant publications from 1990 using Online Contents, Netherlands Central Catalogue (NCC), Catalogues of the University Library, Medline, MEMIC (Centre for Data and Information management), catalogues of the Netherlands Institute for Health Services Research (NIVEL) and the Netherlands Institute for Gerontology. The key-words used are mentioned in Table 1. The search was limited to those studies, which focused on the subjectively perceived needs or wants of elderly people.

Eventually nineteen studies were selected. The way in which the elderly could express their needs differed strongly. Some studies subjected the respondents to (semi)-structured questionnaires or interviews [13, 14], while still other studies used in-depth interview techniques [15-18], while other methods of data collection included panel discussions with senior citizen [9], conceptmapping [19] and working conferences with elderly people [20].

Table 1 Key words in Dutch and English

\begin{tabular}{|c|c|c|c|}
\hline & $\begin{array}{l}\text { Online contents, NCC, } \\
\text { CBUM, Memic }\end{array}$ & Medline & Nivel, NIG \\
\hline Keywords & $\begin{array}{l}\text { Zorgbehoefte, Ouderen } \\
\text { Behoefte, } \\
\text { Behoefteonderzoek }\end{array}$ & $\begin{array}{l}\text { Needs-assessment } \\
\text { Elderly } \\
\text { Health-services-needs-and-demands } \\
\text { Needs, Wants, Desire }\end{array}$ & $\begin{array}{l}\text { Zorgbehoefte } \\
\text { Zorgvraag } \\
\text { Ouderenzorg }\end{array}$ \\
\hline
\end{tabular}

\section{Interviews}

A qualitative research method has been used because the research questions directly refer to the lives, experiences, behaviour and emotions of people as well as the functioning of organizations, social movements and cultural phenomena $[21,22]$.

We conducted in-depth interviews with seventeen respondents. The primary aim of these interviews was to define the concept 'need for care' as it was understood by the elderly people themselves. At the same time, the results of the interviews were used to complete the results of the literature review.

In order to generate a broad spectrum of the perceived needs of elderly people, we worked with a heterogeneous research population. The elderly people selected differed in terms of their functional status, service use (ranging from no use to care in a nursing home), housing (ranging from living independently in the community to admission into a nursing home) and living conditions (alone or with others). Elderly people who were not able to participate in an interview due 
to their cognitive status were excluded.

The interviews were recorded and fully transcribed. The transcripts were systematically analyzed per subject of conversation, for instance transport, housing, perceived obstacles to care, etc.

The Orem's Self Care Deficit Theory of Nursing [6, 23] was used to structure the results of the literature and interviews. Self-care is defined by Orem (1991) as "the voluntary regulation of one's own human functioning and development that is necessary for individuals to maintain life, health, and well-being". Deficits in self-care are eventually the motivation behind demanding adequate support and help. We have opted for this theory in order to structure the results because of the following arguments:

- A broad definition has been used with regard to a 'healthy existence'. Not only is good health important, but well-being, human structural integrity, human functioning and development are also essential components. Old age comes with its shortcomings. Full recovery from most functional impairments is often impossible, so elderly people have to rearrange their lives taking into account these functional impairments. This broad approach to a healthy existence allows them to do so within this;

- In this theory elderly people themselves take the lead in maintaining life, health and well-being. This approximation fits in with the liberated and mature attitude of today's elderly who prefer to live independently;

- A distinction has been made between self-care demands and deficits. Generally speaking, these deficits are the immediate cause for a demand for care and support. For instance, social relationships are important conditions for a good existence. To maintain these social contacts, elderly people express the need for certain services and support like transport or devices to support walking. By doing so, their intention is to overcome social isolation;

- A distinction has been made between universal self-care requisites, developmental self-care requisites and health-deviation self-care requisites. These various goals underscore different aspects of life, including those when a person becomes older and has to overcome functional impairments.

\section{RESULTS}

The concept of need for care

In the literature studied, an unambiguous definition from a client's perspective of the concept of 'need for care' is lacking. Despite the fact that all the titles and abstracts of the selected studies contain the word 'need for care', the explanation of this concept varies quite widely. The following descriptions have been found: the need for services [24], the need for assistance based on ADL and IADL assessment $[25,26]$, the actual demand for care $[15,20]$, service use $[13,25,27]$, 
satisfaction of elderly with the services offered [27], the wants and preferences of elderly people in specific care situations [28], the wishes and needs of disabled elderly people living at home [29], the obstacles to care and housing as perceived by elderly people $[9,14,15,24,30]$, the aspects of care highly appreciate by elderly people [15], wishes of elderly people living in homes for the elderly with regard to their living conditions [31], wishes of elderly people who prefer living independently in the community [17], motives behind admission into homes for the elderly $[25,32]$, choice of a client-centred budget rather than care 'in kind' as an indicator for bottlenecks experienced in care and wants [33], quality of care in homes for the elderly [16], as well as wants and preferences of elderly people concerning a newly-built area in the city [19]. All the studies reviewed showed that the need for care of elderly people should not be limited to care services offered by health-care institutions, but should also take into account well-being and housing.

When talking to the respondents about their need for care, it was striking that they immediately brought up their needs and wants for services and support, which would enable them to continue to live in their homes as long as possible. These services should therefore enable them to continue their lives at home and maintain autonomy and control of their daily activities. The services mentioned during the interviews covered a wide range of public services (e.g., transport, accessibility of public facilities like shops, parks, banks and so on), community-based services (e.g., tailored care at home, social activities in the neighbourhood, meals-on-wheels, transport facilities especially for disabled elderly people) and home adaptations like adjustments in the house and assistive technology (e.g., a personal emergency response system). It can be concluded that the issues brought up regarding the concept 'need for care' are broad, touching on many spheres of life. In order for responses to be effective they must extend beyond the field of health care so they can best encompass the many variables influencing well-being and independence later in life.

\section{Nature of needs for care}

Particularly during the interviews it became apparent that elderly people related their need for care and support to more basic human needs, such as the need for independence/autonomy, social relationships, security and pleasurable activities or stimulation. In other words, elderly people need care and assistance in order to maintain their autonomy, that is, to live independently in the community as long as possible and remain in control of their own lives. This differentiation between basic human needs (universal self-care requisites, developmental selfcare requisites and health deviation self-care requisites), on the one hand, and the need for care and support, on the other, will be also made in the following section dealing with the results of the study.

\section{Universal self-care requisites}

Universally required goals have their origins in what is known and what is 
validated, or what is in the process of being validated, about human structural and functional integrity at various stages of life, such as the maintenance of sufficient intake of air, water, food and care associated with elimination processes and excrements. In addition, the maintenance of a balance between activity and rest, solitude and social interaction are also mentioned as universal goals $[6,23]$. In the literature and interviews with elderly people these requisites are not mentioned. However, elderly people do point out the significance of food. They underscore the importance of services supplying decent hot meals to elderly people at home, the existence of grocery stores in the near environment and the need for assistance in grocery shopping [14, 15, 17, 18, 20, 24, 27, 29, 30]. This need for assistance appears when elderly people are no longer able to walk long distances, carry their groceries and cook their own meals. Elderly people emphasize that these services should be available (without any waiting lists) and offer good-quality hot meals. Besides, the elderly would like to have a diverse supply of services in this area that they can choose from.

Another important need regularly expressed by the elderly, is the maintenance of a balance between rest and activity $[6,23]$. In several studies [13, $15,17,24]$, but in particular during the interviews, elderly people brought up this goal. First of all, this was because activity can prevent further deterioration of physical and cognitive abilities. One of the respondents, an 80-year-old widow who activates elderly people in a nursing home by making music and talking about the old days, explains that by activating. 'Elderly people relive the old days and start talking about their own lives. Their standing and self-respect often depends on what other people know about them. The pride with which these people tell their life story is often very touching.' Secondly, activities are necessary in order to fill up the plentiful leisure time and to maintain social contacts. Elderly people stress the need for serious activities such as training to keep their memory active, volunteer work or membership in a music or reading club $[17,24]$. Activities especially set up for elderly people so they can exercise are also desirable $[13,15]$. Elderly people also mentioned that there is too much emphasis on pleasurable activities like card playing and bingo [17]. Additionally, homes for the elderly and nursing homes devote too little attention to activating or stimulating their residents. This last aspect was mentioned during one interview: 'Except for eating, drinking coffee together and playing bingo from time to time, nothing really bappens' (male, 67 years old, who visits a nursing home on a day-care-only basis). All respondents agree on one aspect: more attention should be paid to the obstacles and impossibilities in regard to maintaining (pleasurable) activities at home and inside an intramural setting. Obstacles include the lack of knowledge about the supply of activities available on a regional, community-based level, as well as financial barriers and inadequate transport.

Both the literature $[15,17,24,25,27,34]$ and the respondents paid a great deal of attention to the importance of social relationships in general, and the prevention of social isolation in particular. It is assumed that independent living 
in a familiar environment contributes to the maintenance of social contacts [24, 27]. All the same, lack of social contacts in the near environment can be a major cause for registering for admission to a home for the elderly [24, 25]. As a part of social relationships, the importance of transport should be considered. Without adequate transport it is difficult if not impossible to visit family or friends. Problems relating to transport as perceived by elderly people were often mentioned. According to the elderly, public transport should be considerable improved and adjusted to the specific needs of older people. The following specific aspects or improvements were mentioned: more bus stops, better connections during the evening and holidays, more frequent (bus) services, cheaper tickets, and more respectful and customer-friendly treatment of elderly people. To illustrate this, a respondent (female, 65 years old) pointed out that ' $a$ bus is available from the centre of the village only twice a day'. This frequency was perceived to be too low, and the location of the bus stop was too far away. This woman was unable to walk to the centre of the village. Apart from public transport, the quality of transport facilities, in particular that for disabled elderly people, needed improvement. According to elderly people, the following aspects left room for upgrading: buses should run as scheduled, bus tickets should be cheaper, the application procedure should be easier and the waiting period should be shortened, the transport region should be widened, there should be more bus stops (especially in smaller regions) and the bus driver should behave in a more customer-friendly way. Finally, more publicity should be given about modifying transport for frail and disabled people [14, 15, 24, 35]. In order to prevent elderly people from becoming socially isolated, a more active role of voluntary workers is desirable $[15,24]$, as well as more adequate information about the services offered by volunteer groups [17]. Community-based care and services should especially pay attention to the problem of the social isolation of elderly people still living independently in the community [25].

The need of elderly people to continue a normal human development within social groups, in line with human potential and the human desire to be normal, came up extensively. In order to function in society as normally as possible, elderly people require public services and facilities that are accessible and userfriendly for older persons, and especially for those with physical impairments and disabilities [14, 15, 17, 18, 20, 24, 27]. These services and facilities are not always available. One respondent put this as follows: 'Our society is not equipped for disabled people' (female, 65 years old). Many examples are given, varying from inaccessible entrances to public buildings or facilities (banks, post offices, public conveniences) for rollators and wheelchairs, as well as buildings, houses and restaurants with several floors but no elevator, in addition to a lack of disabled parking spaces near shops. As a result, elderly people are limited in their opportunities to fully participate in public life (citizenship). Another aspect brought up by elderly people in this category is the lack of housing responsive to the needs of older persons with impairments, such as senior housing or 
adjusted ground-floor apartments, not to mention the waiting lists for admission to homes for the elderly, retirement communities, assisted living facilities or sheltered accomodations $[15,20]$. Elderly people want society to be aware of their needs as citizens.

\section{Developmental self-care requisites}

Developmental-related needs arise as a result of a human dynamic process involving circumstances, events and functioning in each individual existing unit. Ageing, functional impairments and the death of a partner are examples of events and changing circumstances, which can cause developmental requisites [6, 23]. Clearly, elderly people prefer to live independently and want to be in control of their own lives as long as possible, even in situations where they face an increasing need for care and support [13-15, 17, 18, 20, 24, 27, 29-31, 33]. Elderly people associate the need for independence with feelings of control, freedom of choice and privacy, and with the preference for their own home and the familiar living environment where they have lived for a long time: 'Doing things your own way' (female, 80 years old). The anxiety over losing control over and a voice in important matters can be reason enough for elderly people not to express a perceived need [29]. Based on the literature studied and the interviews, numerous suggestions, conditions and circumstances have been found, which can enable elderly people to keep their autonomy and independence (see Table 2).

As part of the issue of independence and autonomy, elderly people point to the importance of privacy. They indicate that their privacy is guaranteed in a more proper way if they can rely on the same caregiver everyday [24] and can keep their own general practitioner after admission to a nursing home or home for the elderly $[15,16,20,24]$. In addition, they underscore the significance of the available health care, especially when assistance is needed for a long period of time or when personal care is needed [25, 28, 29].

Professional and informal caregivers should also value and consider the specific wishes, perception and habits of the clients: 'First, I want them to clean the living room. Just in case I receive visitors unexpectedly' (female, 65 years old). That is why caregivers should be informed about the habits and background of elderly persons in their case at the beginning of their work relation. Unfortunately, this is not always the case. This aspect only came up during the interviews.

Elderly people also explain how devices at home can support them in maintaining their privacy. A good example is an intercom next to the bed to enable a bedridden person to open the front door. This device enables people with serious impairments to speak to visitors themselves and decide to admit a guest independently: 'At first my neighbours opened the front door to show my guests in. As a result they also joined in for the sake of company. I hated this situation' (female, 65 years old, bedridden). 
Table 2 Conditions, suggestions and wants with regard to care, social services and housing so as to enable elderly people to live independently as long as possible.

\section{CARE}

flexible community based home care ( 24 hours a day, no waiting lists)

- client-centred assistance from others especially with (household) activities requiring a great deal of physical effort (mopping, grocery shopping, making the bed, doing and ironing the laundry). This means that the wishes of the clients with regard to this assistance should be paramount, instead of adhering to the job description for caregivers.

- assistance from others with the maintenance of the house and garden (e.g., home repair, gardener)

- assistive devices and home modifications in order to support elderly people in their daily activities (e.g., telephone with light-up large numbers and letters, microwave, rollator, raised bed or toilet, stair lift, wheelchair, grab rails, widened doorways, chair in bath or shower, antiskid mat in the bath)

- possibility to receive intramural care at home

\section{SOCIAL SERVICES}

- accessible shops and other facilities in the nearby environment such as mailbox, church, bank, library and hospital, and adequate public and community transit system delivery of hot meals at home (meals-on -wheels or catering companies who deliver at home)

- good information about all facilities for the elderly people in the community

- assistive technology like personal emergency response systems (PERS) and special telephones. PERS are devices that can attend to emergencies, such as falls, that might occurs at home. The telephones are equipped with amplifiers and speakers so elderly people with hearing and vision problems can still use the phone, an important device in preventing social isolation.

\section{HOUSING}

- $\quad$ secure living environment: police in the streets, sufficient street lighting, a suitable pavement for devices like wheelchairs and rollators (sloping kerbs, no obstacles)

- secure housing: safety precautions in the home (smoke detector installation, security system)

- sufficient supply of housing for elderly people (all rooms on the ground floor, without thresholds, near to public facilities)

- parking facilities in front of the door

\section{Health-deviation self-care requisites}

These requisites exist for people who are ill or injured, have specific forms of pathology including defects and disabilities, and who are under medical diagnosis and treatment $[6,23]$. It is of utmost importance that these people are able to search for and obtain the appropriate medical assistance (self-care agency). On the other hand, this care should be available when needed. These health-related needs occur in all the studies and interviews. In summary, elderly people need:

- accessible health care, that is, there should be no waiting lists or complex entry procedures; 
- a transparent care supply, so they know what is available;

- flexible care, which can be adjusted to the specific needs of the consumer;

- high-quality care ensuring the following aspects: expertise, decent treatment, on call 24- hours-per-day care, and reliability, specific attention to family caregiver(s).

This is not always the case according to a respondent (female, 65 years old) and her partner (male, 72 years old): 'The present health care system is not able to respond to acute bealth care demands due to waiting lists and the complex entry procedures of the assessment agencies (...) Is that what we paid an insurance premium for all our lives?'

A pleasant housing and living environment are particularly important aspects with regard to nursing homes and homes for the elderly [16]. The first matter of significance is that the need for privacy, autonomy and independence for elderly people in these intramural settings should respected. Restrictive house regulations are undesirable. Moreover, the intramural-living elderly want to be able to choose their own physicians and be allowed to keep pets. Elderly people also brought up the significance of admission to a home for the elderly in the place of origin [20]. Table 3 shows an overview of the services, which elderly people wished for with regard to nursing home care and homes for the elderly $[15,16,20,31]$.

Table 3 Needs of elderly people with regard to the services offered in homes for the elderly and nursing homes on the areas housing, social services and care.

\section{CARE}

the presence of a clergyman

availability of laundry services

a sufficient amount of staff available

\section{SOCIAL SERVICES}

- a varied supply of social activities for residents

- enough room and accommodations for social activities and recreation

- hot meals à la carte

- client-centred education regarding all existing care, social services and facilities

- a shop for daily groceries

- the demand for an opportunity to comment on housing issues and the organization of activities

- the presence of a clients' association

- a heterogeneous population of residents in terms of age and functional status

- $\quad$ attention to security issue likes covered passageways, caretaker or warden, personal emergency response systems

\section{HOUSING}

a bedroom separated from the living room

in cases of the use of a wheelchair or rollator, a roomy living room

quest rooms for visitors 


\section{DISCUSSION}

In this study we have examined the concept of 'need for care' from a clientcentred perspective, as well as the perceived needs for care and support of elderly people, by means of a literature review and interviews with elderly people. The studies we examined, revealed a great variety of research methods, definitions of the concept of 'need for care', research aims, populations and measurements. Despite the fact that the interviews did not yield any new information, the extensive reflections of elderly people were important for understanding their perceived need for services and support within the context of their more basic needs and requisites. Namely, needs for care seem to arise when elderly people are no longer able to fulfil basic needs by themselves, such as the need for autonomy, social relationships, day activities, social participation (citizenship) and food. In other words, if elderly are no longer able to function independently despite being assisted by volunteers, for instance, they experience a shortcoming, and they will seek and ask for formal help. The need for care then becomes a translation of a perceived need into a certain amount and type of care and support, which should enable the person in question to compensate for the shortcoming in self-care [5].

It should be noted that the need for autonomy was especially predominant, that is, they wish to continue to live in their homes independently and be in control of their daily lives. More than that, most respondents began the in-depth interviews with this subject. Each time again the respondents emphasized that being in control of their own lives was the most important basic need, even when impairments severely affected their abilities and independence.

Furthermore, it should be noted that the above-mentioned list of basic needs is not exhaustive. The well-known need theories of Maslow (1954), Deci and Ryan (1985) and Bandura (1997) describe additional basic needs which are not mentioned in the literature studied and in the interviews [36-38]. Examples of these include the need for 'self-realization', 'having sufficient money' and 'to be liked by others'.

The Orem's Self Care Deficit Theory of Nursing is very useful when distinguishing basic human needs (e.g., pleasurable stimulation) and needs for services like day care in order to compensate for or prevent a shortcoming (feeling bored or lonely). However, this theory does not offer a satisfying framework when classifying the various needs subsequently expressed by elderly people. These needs varied from 'fixing paving stones' to 'simplifying application procedures for assistive devices'. The perceived problems relating to waiting lists were brought up fairly frequently, as was the (lack of) quality of care services and facilities. Furthermore, the perceived needs of the elderly extend to three areas of support: care, well-being and housing, that serves both independent living elderly and elderly people living in an intramural setting. For this wide variety of needs, Orem's theory offers less to go by. But is it worthwhile to structure these 
needs? After all, the way in which and the extent to which people perceive deficits in self-care and subsequently try to overcome them, strongly depends on their personal wishes, circumstances and possibilities (functional status, income, informal care, living and housing conditions and environment, self-care ability). Moreover, depending on (changes in) their personal circumstances people differ in the relative importance they attribute to their basic needs. For instance, while the need for a career after retirement will decrease, the need for social relatedness with (grand)children and other relatives is likely to increase. The question is to what extent client's individualization and maturity have spurred this differentiation in care needs.

Apart from, the variation in needs and the perceived importance of these needs, the extent to which elderly people experience deficits in self-care can also vary. In other words, based on the results it is impossible to outline the variation in perceived needs (nature and extent) and any related demand for care and services, because the personal circumstances and specific characteristics of elderly people are too diverse. Nevertheless, this very information is of unmistakable importance to policy makers in developing a demand-driven health care system with special attention to housing and well-being. At the same time, the question is raised as to whether it is altogether possible to map all the circumstances, determinants and conditions that may affect the demand for care and support and hence the supply of care. In other words, is a demand-driven care system feasible?

Van Bilsen et al. (2003) have developed a model regarding the relationship between care needs and the demand for (health care) services that may answer this question. However, more research is needed [4, 39].

\section{CONCLUSION}

Elderly people define the need for care as everything that is an obstacle to independent living. Care for elderly people should therefore entail more than health care alone. Services and facilities in the areas of housing, transport and well-being should also be taken into account, as these will enable them to fulfil their more basic needs for autonomy, social relationships and leisure activities. Despite the great diversity of needs, elderly people did not mention any services or facilities that were not yet offered. Nevertheless, critical remarks were made with regard to the quantity and quality of the available supply of care services. In terms of quantity, the elderly referred to the waiting lists in the housing market, health care and services like meals-on-wheels and special transport for disabled elderly people. Complaints about the quality of care centred around complex regulations and admission procedures, fragmented information and educational material, inaccessible public services and transport facilities. The organization and care supply of home care and intramural institutions are not sufficiently tailored to the demand for health care. Little insight has been gained 
into how the listed needs can be translated into a demand-driven client-centred supply of care and services taking into account the heterogeneity of the elderly population as well as the diversity and variability of the perceived deficits. More fundamental research is needed.

\section{REFERENCES}

1. Kasdorp JP. Zorg op maat (Tailored care). The Haque: Council for Public Health and Health Care (RVZ) 1995.

2. Hellings DA, Eywoudt MJH, Borgers MTA, Hamers JPH, Rongen WMGM, Maaskant MA. Aard en omvang van zorgbehoefte in Limburg. Een literatuurstudie (The nature and extent of health care needs in the province of Limburg. A literature review). Universiteit Maastricht 1999.

3. Stevens JAM, Lalleman AW, Mathijssen SW, Eijk W van, Hamers JPH. Zorg in Limburg. De AWBZ-sector in kaart gebracht (Care in the southern part of the Netherlands. An overview of the Care and Nursing sector). Maastricht: Universitaire Pers Maastricht 2000.

4. Van Bilsen PMA, Hamers JPH, Groot W. Spreeuwenberg C. Welke zorg vragen ouderen? (What care do elderly people ask for?). Maastricht: Universitaire Pers Maastricht 2002.

5. Donabedian MPH. Aspects of Medical Care Administration. Specifying Requirements for Health Care. Cambridge, Massachusetts: Harvard University Press 1973.

6. Orem DE. Nursing; Concepts of Practice. St. Louis: Mosby-Year Book, Inc. 1991.

7. Te Wierik MJM. Verpleeghuisopname. Een onderzoek naar factoren die van invloed zijn op verpleeghuisopname en het verloop daarvan. (Nursing home admittance. Factors associated with nursing home admittance) Rijksuniversiteit Limburg: Maastricht 1991.

8. Frederiks CMA, Zorgbehoefte van en de zorgverlening aan ouderen (Physical limitations and use and professional home care by elderly people). Rijksuniversiteit Limburg: Maastricht 1990.

9. Ministry of Health, Welfare and Sport. Zicht op Zorg. Plan van aanpak Modernisering AWBZ (A perception on care. Policy on the 'Modernization of the Exceptional Medical Expenses Act). The Hague: Ministry for Health, Welfare and Sport (VWS) 1999.

10. Dijkstra G, Groothoff JW, Post D. De indicatie voor een verzorgingshuis of verpleeghuis. (The assessment of nursing home care or residential care). Tijdschrift voor Gerontologie en Geriatrie 1999, 30:114-120.

11. Boeije HR, Dungen AWL, Pool A. Een verzorgde toekomst. Toekomstscenario's voor verpleging en veryorging. (A well-cared-for future). Utrecht: STG/LCVV/NIZW/De Tijdstroom 1997.

12. Bradshaw J. A taxonomy of social need, in Portfolio for health: problems and progress in medical care. G. McLachlan, Editor. Nuffield Provincial Hospital: London 1972.

13. GGD. 55+ enquête Provincie Flevoland. (Poll of 55+ seniors in the province of Flevoland). GGD Flevoland 1995.

14. Jongen BCM, Heusschen JMP, Van Someren AEW. Rapportage Evaluatie Ouderenbeleid Gemeente Kerkrade (Evaluative reportage with regard to policy on elderly people living in Kerkrade). Gemeente Kerkrade 1999.

15. KBO, Rapport Regionale Zorgvisie Ouderen. Horst-Sevenum, Venray, Maasdorpen (A regional view of the care for elderly people). KBO-Limburg 1997. 
Chapter 2

16. Landelijke Organisatie Bewonerscommissies Bejaardenhuizen. Kwaliteit van verzorgingshuizen. Bewoners aan het woord. (Quality of homes for the elderly. Elderly people speaking). LOBB 1998.

17. Wiggers JA. Ouderen aan het woord. Een kwalitatief onderzoek naar de behoefte en wensen van Leidse 75-plussers op de gebieden wonen, bulp/ zorg en sociale participatie. (Elderly people speaking. A qualitative study on the needs of elderly people aged 75 and older concerning housing, care and social participation). Rotterdam 1993.

18. Splann Krothe J. Giving voice to Elderly People: Community-Based Long Term Care. Public Health Nursing 1997, 14:217-226.

19. Hamers $\mathrm{H}$, Bartels J. Het bepalen van de behoefte aan zorgvoorzieningen. Consumenteninbreng bij de planning. (The assessment of health care needs and services). Kwaliteit \& Zorg 1996, 4:63-72.

20. Zorginstellingen regio Westelijke Mijnstreek. Zorgketens in de Westelijke Mijnstreek (Chains of care in the Westelijke Mijnstreek region). Functieplan in het kader van de regiovisie voor de Ouderenzorg Westelijke Mijnstreek 1998.

21. Munhall PL, Boyd Oiler C. Nursing research. A qualitative perspective. New York, 1993.

22. Strauss A, Corbin J. Basics of qualitative research. Techniques and Procedures for developing Grounded Theory. Thousand Oaks, London New Delhi: Sage publications 1998.

23. Brouns G, Zelfzorgtheorie van Orem. (Self-care Deficit Nursing Theory by Orem). Dwingeloo: KAVANAH 1996.

24. Van Tits MHL, Lambeck S, Muffels RJA. 55-plussers in beeld. Een onderzoek naar de vraag van ouderen in West-Brabant op het gebied van zorg, wonen, en welzign (The demand for care, housing and well-being of seniors aged 55 years and older examined). IVA Tilburg 2000.

25. Te Wierik MJM, Frederiks CMA. De hulpbehoefte en opnamewens van positief geïndiceerden. Een vergelijking met verzorgingshuisbewoners (The care needs and wish to be admitted of applicants to homes for the aged; A comparison with residents of homes for the aged). Tijdscbrift voor Gerontologie en Geriatriatrie 1990, 21:115-123.

26. Penris M. De zorgbehoefte van bejaarden in de stad Utrecht. (The need for care of elderly people in the City of Utrecht). GG\&GD Gemeente Utrecht 1991.

27. Ooijendijk W, Bootsma-van der Wiel A, Gusseloo, J. 55+ wil iets anders dan 75+. Ouderen interviewen ouderen over wonen, zorg en welzijn. (Elderly people interviewing other elderly people about housing, care and well-being) Senior 1997, 10:25-27.

28. Wielink G, De Klerk MMY, Huijsman R. Voorkeuren voor hulpverlening. Resultaten van een onderzoek onder alleenwonende ouderen (Preferences for care: results of a study among single elderly in the Netheralnds. Tijdschrift Sociale Geneeskunde 1995, 73:367-374.

29. Bijsterveld HJ. Het ouderenperspectief op thuiszorg. Wensen en behoeften van ouderen ten aanzien van de thuis(zorg)situatie in Friesland (Elderly people and their perspective on homecare; wishes and needs of the elderly in the home (care) situation in the Dutch province of Friesland). Universiteit van Groningen: Groningen 2001.

30. De Boer CJ, Van der Molen F, Sijtsma P, Voogel H. Huisvesting, buisvestingswensen en zorgbehoefte van 50 tot 75 jarigen in Oostellingswerf. (Housing, preferences and the need for care of people aged 50 up to 75 living in Oostellingswerf). Rijksuniversiteit Groningen, Groningen 1994.

31. Naafs J. Verzorgingshuizen op weg naar bun toekomst. (Homes for the elderly on their way to the future). Tilburg: IVA Tilburg 1994. 
32. Steverink N. Zo lang mogelijk zelfstandig. Naar een verklaring van verschillen in oriëntatie ten aanzien van opname in een verzorgingstehuis onder fysiek kwetsbare ouderen (Living independently as long as possible. Towards an explanation for the variety in need among frail elderly people in terms of residential care). Rijksuniversiteit Groningen: Groningen 1996.

33. Ramakers C, Miltenburg T, Mensink, J. Het cliëntgebonden budget (the client-centred budget). Tijdschrift voor Verpleegkundigen 1994, 8:249-253.

34. Broese van Groenou M, Thomése F. Het relatieve belang van zelfstandig wonen voor het sociaal functioneren van ouderen (The relative importance of independent living on social functioning of elderly people). Tijdschrift voor Gerontologie en Geriatriatrie 1996, 27:150-158.

35. De Klerk MMY (Ed). Rapportage ouderen 2001. Veranderingen in de leefsituatie (Report elderly people 2001. Changes in social situation). Social and Cultural Planning Office of the Netherlands (SCP): The Hague 2001.

36. Maslow A. Motivation and personality. New York: Harper \& Row 1954.

37. Deci EL, Ryan RM. Intrinsic motivation and self determination in buman behavior. New York: Plenum Press 1985.

38. Bandura A. Self-efficacy: The exercise of control. New York: Freeman 1997.

39. Van Bilsen PMA, Hamers JPH, Groot W, Spreeuwenberg C. The relations between health care needs and demands: a theoretical model. Rev. Esp. Geriatr. Gerontol 2003, 38:194-195. 


\section{DEMAND OF ELDERLY PEOPLE FOR RESIDENTIAL CARE: AN EXPLORATIVE STUDY}

PMA van Bilsen, JPH Hamers, W Groot \& C Spreeuwenberg

Published in BMC Health Services Research 2006, 6:39. 


\section{ABSTRACT}

Because of the rapid aging population, the demand for residential care exceeds availability. This paper presents the results of a study that focuses on the demand of elderly people for residential care and determinants (elderly people's personal characteristics, needs and resources) that are associated with this demand. Furthermore, the accuracy of the waiting list as a reflection of this demand has been examined.

Sixty seven elderly people waiting for admission into a home for the elderly, are subjected to semi-structured interviews. The data are analyzed using multivariate statistics.

Elderly people who indicate that they would refuse an offer of admission into a home for the elderly feel healthier $(\mathrm{p}=0.02)$, have greater self-care agency $(p=0.02)$ and perceive less necessity of admission $(p<0.01)$, compared to those who would accept such an offer. Especially the inability to manage everyday activities and the lack of a social network are highly associated with the elderly people's demand for residential care. Furthermore, it is evident that waiting lists for homes for the elderly do not accurately reflect the demand for residential care, since $35 \%$ of the elderly people on a waiting list did not actually experience an immediate demand for residential care and stated that they would not accept an offer of admission. Quite a lot of respondents just registered out of a sense of precaution; a strategic decision dictated by current shortages in care provision and a vulnerable health status.

The results contribute to the understanding of waiting lists and the demand for residential care. It became apparent that not everybody who asks for admission into a home for the elderly, really needed it. The importance of elderly people's resources like social networks and the ability to manage everyday activities in relation to the demand for care became clear. These findings are important because they indicate that resources also play a role in predicting elderly people's demand and as a result can guide the development and the (re)design of adequate health care services. 


\section{BACKGROUND}

In most Western countries, the health care system faces serious problems as a result of social trends and advances in medicine such as the ageing of the population, changes in the provision of care, increases in number of wellinformed patients and predictive medical information. These changes have profound impact on the nature and the extent of health care services for elderly people. On the one hand, the ageing of the population has already led to staffing shortages in care and delay in capacity expansion [1-4] showing that demand exceeds availability resulting in waiting lists. On the other hand, elderly people increasingly want and demand a more varied provision of health care services at home so they can age in their familiar home environment as long as possible [4,6-12]. Therefore, policy makers and researchers argue that waiting lists possibly do not adequately reflect elderly people's demands and as a result do not adequately reflect the services elderly prefer. Consequently, this raises the question what services should be offered in order to meet the demand for health care of elderly people?

To answer this question, several studies [e.g.,1,9,10,11,13,14] have been reviewed which resulted in the development of a theoretical model on the relationship between elderly people's needs, resources and their demand for care (see Figure 1). A major assumption in this model is that people address universal needs (e.g., autonomy, self-esteem) and that these needs can be influenced by a range of personal characteristics (e.g., age, health status, cognitive status). Besides, people attribute a prioritisation of relative importance to these universal needs dependent on culture, person-bound characteristics of people (e.g., age, gender, social class) and changing circumstances (e.g., household composition) [15-18]. The second major assumption is that people use resources like self-care agency, income, informal care and a social network to fulfil their needs. A demand for care is a result of one or more unmet needs, mainly due to insufficiencies in available resources. This is the third major assumption in the model.

The aim of this study is get insight into the determinants of the demand for residential care. The model serves as a framework to study these determinants and related factors. In addition, the question whether waiting lists do accurate reflect the elderly people's demands, is evaluated.

This study focuses on elderly people on a waiting list for a home for the elderly in the Netherlands. Homes for the elderly are institutions providing living conditions for old people who are unable to live independent alone, but usually require no more nursing care than can be given by a visiting nurse [19]. Elderly people in the Netherlands on a waiting list, previously made an official request for residential care at an assessment agency's office. These agencies are established in order to control the growing demand by formalizing and standardizing the process of determining the patient's needs for the health services to which they are entitled [20,21]. Without approval of these assessment 
offices, the caregiver is not allowed to provide care. The central questions in this study are:

- What determinants are associated with the demand for admission into a home for the elderly?

- Are waiting lists for admission into a home for the elderly an accurate reflection of the demands of elderly people for services in later life?

Figure 1 The relations between health care needs, resources and demands

\section{Culture}
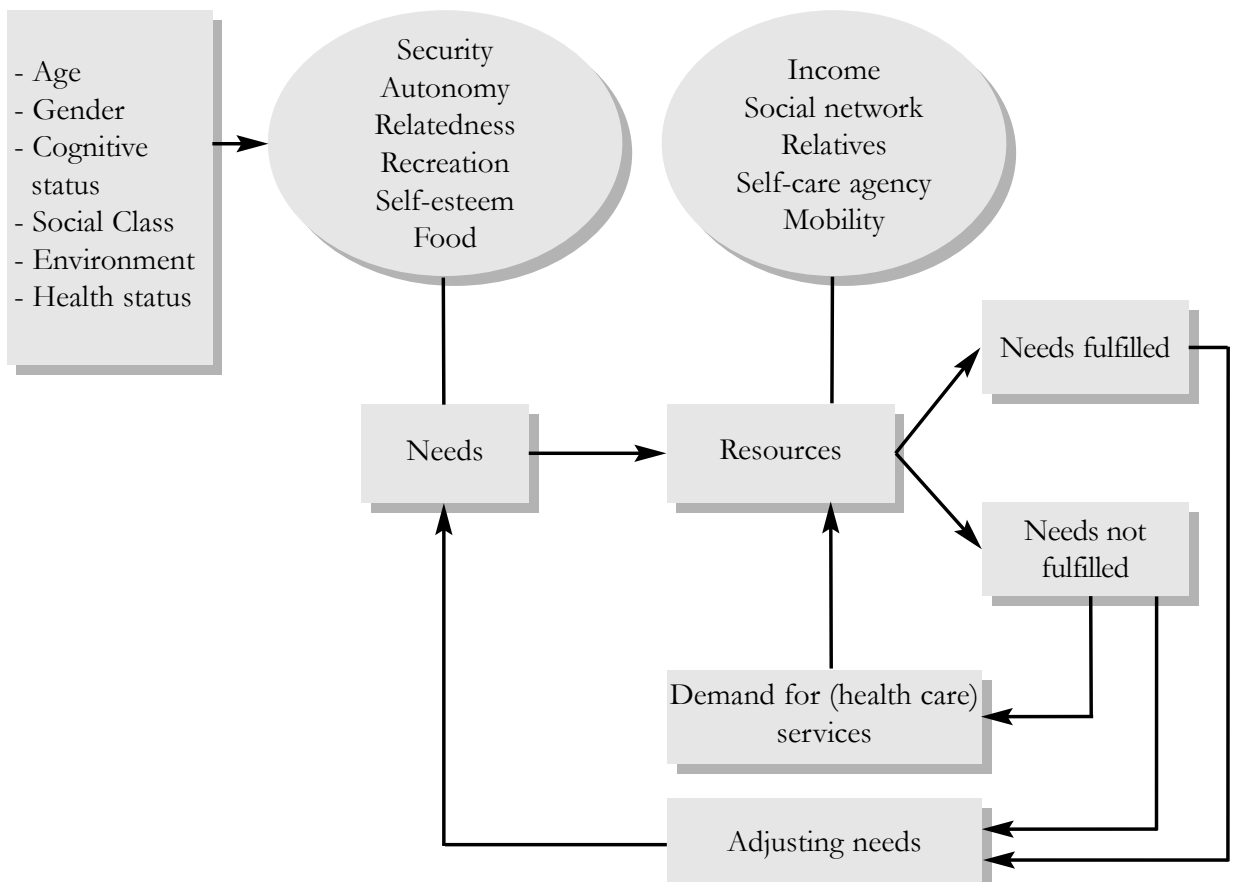
Table 1 Total response and overview of reasons for non-response $(n=200)$

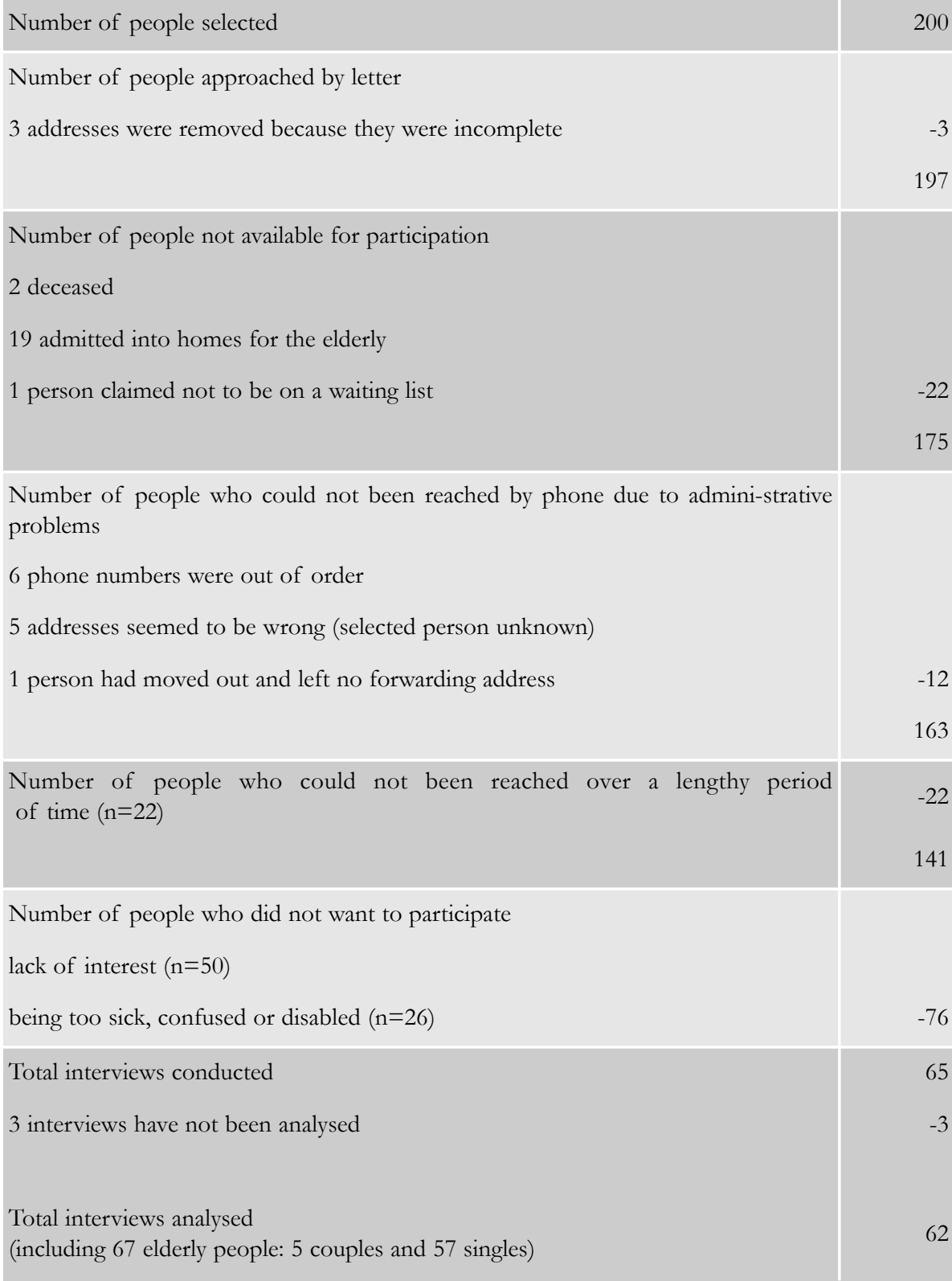

\section{METHODS}

A cross-sectional design was used. Over a period of two months elderly persons who were registered for admission into a home for the elderly were interviewed.

Health insurance agencies in Limburg (a province in the south of the Netherlands) were asked to randomly select 200 elderly people registered on a waiting list for a home for the elderly. At that moment, there were 1693 elderly 
people waiting for admission into a home for the elderly in Limburg [5]. The mailing list consist of 197 addresses of elderly people (3 addresses were removed because of incompleteness). Subsequently, a letter was sent informing the recipients about this study. A few days after this letter had been sent, the people were contacted by telephone to ask whether they would like to participate. If they agreed, a date was set for an interview. Reasons for refusing were systematically recorded. Eleven interviewers, who had been carefully instructed, interviewed the people at home. All interviews were taped and fully transcribed.

A considerable part of the 197 selected elderly persons could not be reached by phone or were no longer on the waiting list (see Table 1). Of the remaining prospective participants ( $n=163), 22$ were never reached because there was no answer even though we kept trying for a lengthy period of time, and 50 elderly people showed no interest. These 50 people were not convinced of the usefulness of the research, were too busy with other things (e.g., their social life, home improvement), were afraid of the consequences of cooperation (being removed from a waiting list or the opposite being offered a place in a home) or were tired of all the interviews and consultations they had already had (e.g., with home care organisations, regional assessment agencies, insurance companies). Another 26 elderly people claimed to be too sick, confused or disabled (e.g., because of hearing problems). Eventually, 65 interviews were conducted. Based on the 163 respondents that were reached by phone, the response was thus $40 \%$. It subsequently appeared that 3 interviews could not be used because they had too many missing values. So 62 interviews were analysed, involving 57 singles and 5 couples. The answers of the couples were analyzed separately, so the results relate to the answers of 67 respondents. For an overview of the response and non-response see Table 1.

Complementary quantitative and qualitative data were collected by means of interviews. A semi-structured questionnaire served as a guideline. This questionnaire was developed based on the theoretical model on the relationship between needs, resources and demands (See Figure1) [11]. Questions were asked about the following subjects:

- Personal characteristics (e.g., age, gender, marital status, children, housing);

- Health status (functional status, subjective perception of health, loneliness, memory loss).

Functional status was measured by the Groningen Activity Restriction Scale [22]. Respondents were asked to indicate to what extent they were still able to engage in activities of daily living related to personal care (11 activities) and activities related to independent living ( 7 activities). The respondent had to answer on a 3 -point ordinal scale to what extent they can carry out the activities of daily living either independently or (partly) with help of others ( $1=$ completely 
independent, $2=$ independent with great effort, $3=$ only with help of others). - The Scale of Subjective Welfare was used to measure the subjective perception of health status (5 items), the existence of negative feelings (5 items) and feelings of loneliness (7 items) [23]. The respondents had to answer on a 3-point ordinal scale to what extent they agreed ( $0=$ disagree, $1=$ do not know, $2=$ agree) with statements, such as 'I feel fine,' 'I feel quite healthy,' 'I worry a lot,' 'I often feel sad,' 'I miss a really good friend,' 'I experience an inner void.' Analogous to these items scored on a 3-point ordinal scale to what extent they agreed, three self developed questions were added concerning loss of memory, like 'I have to write down everything I need to remember,' 'I am very forgetful' and 'I do not suffer from memory loss.' Higher scores indicated greater perception of being in good health, having more memory problems, having more negative feelings (sadness, anxiety, worries) or greater loneliness.

- Presence of resources like social network, social participation, income and selfcare agency. Social network was measured by asking whether the respondents were satisfied with regard to the frequency in which they see their children (1 item). Next, 4 items were formulated about the existence of satisfactory contacts with friends, neighbours, family. The respondents had to answer on a 5-point ordinal scale to what extent they agreed with the statements, such as 'I have a lot of close friends' and 'I have a circle of friends on which I can rely when sudden problems arise' ( $1=\mathrm{I}$ strongly disagree, $2=\mathrm{I}$ disagree, $3=$ neither agree or disagree, 4=I agree, 5=I strongly agree). A high score on the self-developed 'social network' items meant that respondents had satisfactory contacts with their children and friends and felt they could rely on them. Another 4 questions measured the extent to which the elderly persons still participated in social life. These self-developed items also had to be answered on a 5-point ordinal scale to what extent they agreed. For example, 'I still do voluntary work,' 'I am still a member of more then one social club.' A higher score indicated that the respondent had a satisfactory social life and was still involved in social activities. Two self-developed items were added about the sufficiency of their income. The respondents had to answer these items yet again on a 5-point ordinal scale to what extent they agreed with the statements posed. For example, 'I have enough income to arrange my life the way I wanted to be,' 'I cannot buy everything that I need.' A higher score indicated that the respondent experienced their income as sufficient.

Self-care agency was measured by 9 items of the ASA-A [24]. Self-care agency is defined as the respondents' capability to search for and obtain continuous care for themselves. Respondents were also asked about their ability to live and eat in a healthy manner. The respondents had to respond to these statements on a 5point ordinal scale to indicate the extent to which they agreed or disagreed. Higher scores meant greater self-care agency ( $1=\mathrm{I}$ strongly disagree, $2=\mathrm{I}$ disagree, $3=$ neither agree or disagree, $4=\mathrm{I}$ agree, $5=\mathrm{I}$ strongly agree).

- Demand for residential care. The demand for admission into a home for the 
elderly was assessed by asking three questions. The first question inquired if they would today accept or refuse an offer to move into a home for the elderly not of their first choice. The second, asked if they would today accept or refuse an offer to move into the home of their first choice. The third question asked the respondents to rate the necessity of admission into a home for the elderly on a 5 -point ordinal scale $(1=$ not at all necessary, $2=$ not necessary, $3=$ neither necessary nor unnecessary, $4=$ necessary, $5=$ very necessary). Besides, four questions were asked about the registration on a waiting list and motives underlying this registration. The respondents were asked if they were on a waiting list for residential care and how long they were registered. The duration of registration was also checked with the formal registration of the administrators. Then the respondents were questioned about their motives underlying their choice to register for residential care by means of an open question. Subsequently, they had to select the motive of most importance.

Table 2 summarises the characteristics of some of the above mentioned measures (Cronbach's $\alpha$, range, sum scores, deviation). In general, the measurement instruments proved to be internally consistent (Cronbach's $\alpha$ range based on the data is between 0.66 and 0.89 ) [25].

Besides descriptive statistics (frequencies, mean, deviation, sum scores, Cronbach's $\alpha$ ) the data were analysed by comparing groups (One-way ANOVA and chi square); respondents who indicated they would accept an offer of admission were compared with those who said they would refuse such an offer, using multivariate statistics (regression analysis). The interviews with the elderly were fully transcribed, allowing the answers ticked by the interviewers to be verified. The interview transcripts also allowed us to gather more detailed information about aspects like the underlying motives to move into a home for the elderly.

Table 2 Range, reliability and mean score (SD) of the measures used

\begin{tabular}{|l|r|r|r|}
\hline \multicolumn{1}{|c|}{ Measures } & Range & \multicolumn{1}{c|}{$\begin{array}{c}\text { Reliability } \\
\text { (Cronbach's } \boldsymbol{\alpha} \text { ) }\end{array}$} & \multicolumn{1}{|c|}{ Mean score (sd) } \\
\hline Functional status & $18-54$ & 0.89 & $33.9(7.0)$ \\
\hline Subjective perception of health status & $0-15$ & 0.83 & $4.6(3.7)$ \\
\hline Memory & $0-9$ & 0.73 & $3.1(2.4)$ \\
\hline Negative feelings: worries, sadness, anxiety & $0-15$ & 0.83 & $3.1(3.2)$ \\
\hline Feelings of loneliness & $0-21$ & 0.79 & $6.4(4.3)$ \\
\hline Social network & $5-25$ & 0.66 & $16.6(4.6)$ \\
\hline Social participation & $4-20$ & 0.76 & $8.6(4.5)$ \\
\hline Self-care agency & $9-45$ & 0.67 & $30.6(4.6)$ \\
\hline
\end{tabular}




\section{RESULTS}

Sample

The sample included 50 female and 17 male respondents $(57$ singles and 5 couples).The average age was 81 years $(\mathrm{SD}=6$, range 55-94). Fifty-three respondents lived on their own while 14 respondents lived together with someone else: partner $(\mathrm{n}=12)$, children $(\mathrm{n}=1)$, others $(\mathrm{n}=1)$. Forty-eight respondents were widowed, 12 married, 2 divorced and 5 respondents were never married. Nearly all of them had children $(\mathrm{n}=60)$. Twenty-seven respondents were living in a non-ground floor apartment or regular house with a first and second floor (without a lift to get to the second floor). Twenty-one respondents were living in single-store houses with only ground-floor rooms but no other adaptations. Thirteen respondents already moved to a ground-floor apartment fully adapted for elderly people. Finally, one respondent temporarily resided in a home for the elderly.

\section{Health}

Seven respondents did not answer the questions on functional status because they wished to stop the interview at this point. The results show that the other 60 respondents needed assistance from others particularly for activities requiring a great deal of physical effort, like certain household activities, going up and down the stairs, moving outside the house, grocery shopping, preparing food and doing and ironing the laundry. Except for 'washing and drying your entire body' and 'looking after your feet,' the respondents were still able to manage their personal care themselves. Those who did need help with personal care predominantly received aid from formal caregivers. In addition to formal caregivers, relatives usually assisted in house activities like grocery shopping and doing and ironing the laundry.

Thirty-three respondents perceived their health as mainly negative (score $\leq 1$ ) (subjective perception of health status). The other responding elderly ( $\mathrm{n}=26)$ were more positive about their health and more likely to confirm that they were feeling fine (score $>1$ ). The results for loss of memory show that there were two almost equally sized groups, one comprising respondents $(\mathrm{n}=31)$ who were annoyed by their (nascent) loss of memory (score $>1$ ) and one comprising respondents $(\mathrm{n}=27)$ who reported that they did not experience any memory problems (score $\leq 1)$. The first group indicated that they were very forgetful and needed to write everything down to remember. Forty-three respondents reported that they had a generally positive attitude to life, meaning that they were usually not sad, worried or anxious (score=1) (negative feelings). Twenty-six respondents did experience feelings of loneliness (score $>1$ ), meaning that they felt left alone and really missed a good friend or the company of others. 
Presence of resources

Thirty-nine respondents stated that they saw their children frequently enough. Thirty-four elderly saw their children at least a few times a week. The analyses showed that 20 respondents did not have a social network or only a very small one (score $\leq 3)$. Nineteen elderly had a neutral score in this respect meaning that they did have some friends and children living nearby, but did not feel it was possible to fall back on them when sudden problems arose. Only 5 respondents still participated in social life (score $\geq 4$ ).

Forty-six respondents had a moderate to satisfactory capability to search and obtain continuous care for themselves (self-care agency). This also included their ability to live and eat in a healthy manner. In terms of the individual items, most respondents seemed to know where to turn to for information about their health and to obtain care.

\section{The demand for residential care}

All respondents were officially on a waiting list for residential care. Three respondents, however, were not aware of this registration with the result that two respondents refused to answer the questions concerning this subject. The other respondents $(n=65)$ of which 5 couples, confirmed being registered for admission into a home for the elderly. The average time on the waiting list was 20 months $(\mathrm{SD}=15)$.

The respondents generally mentioned more than one motive which played a substantial part in their decision to register for admission into a home for the elderly. The average number of motives mentioned was $3(\mathrm{SD}=1.8)$. According to twenty-two respondents $(34 \%)$, the most important reason was out of a sense of precaution. Because of their vulnerable health and the current shortages in care provision, they wanted to ensure that care would be available by the time they needed it. Fourteen respondents $(22 \%)$ stated that their physical or mental disability was of overriding importance. These respondents pointed out that they felt increasingly vulnerable living on their own. The most important motive for another 9 respondents (14\%) was feelings of loneliness.

A large majority of the respondents (59 out of 65 respondents) stated that they would at present refuse an offer of admission to a home that was not their first choice. Besides, 23 respondents (out of 65) would not even accept an offer of admission into the home of their first choice, although 42 respondents would. Further, 27 respondents did not consider admission to be necessary, while 31 respondents did ( 7 respondents judged admission neither necessary or non-necessary). Table 3 presents the results of a comparison between the group of respondents who indicated that they would accept an offer of admission and the group who said that they would refuse such an offer. Respondents who indicated that they would refuse an offer of admission into the home of their first choice felt healthier $(p=0.02)$, had greater self-care agency $(p=0.02)$ and perceived less necessity of admission $(\mathrm{p}<0.01)$, compared to those who would 
accept such an offer. The two groups also differed with regard to their motives underlying their choice to register for residential care. Respondents who would refuse an offer were more likely to be on the waiting list because of a sense of precaution than those who would not refuse such an offer $(p<0.01)$. Respondents who mentioned 'feelings of loneliness' or 'health problems' as the most important motive for wanting to move into a home for the elderly were more likely to accept an offer than those who did not mention one of these reasons as the most important one.

Table 3 Acceptance or refusal of admission into a home for the elderly $(n=65)$

\begin{tabular}{|c|c|c|c|c|}
\hline Characteristics of people & $\begin{array}{c}\text { Missing } \\
\text { Values }\end{array}$ & $\begin{array}{l}\text { Acceptation } \\
\qquad n=42\end{array}$ & $\begin{array}{c}\text { Refusal } \\
n=23\end{array}$ & p-value ${ }^{4}$ \\
\hline Age (SD) ${ }^{1}$ & - & $80(6.5)$ & $83(4.5)$ & 0.12 \\
\hline $\begin{array}{l}\text { Gender }^{2} \\
\text { - male } \\
\text { - female }\end{array}$ & - & $\begin{array}{l}11 \\
31\end{array}$ & $\begin{array}{r}5 \\
18\end{array}$ & 0.69 \\
\hline $\begin{array}{l}\text { Living conditions }^{2} \\
\text { - living alone } \\
\text { - sharing a house with others }\end{array}$ & - & $\begin{array}{r}33 \\
9\end{array}$ & $\begin{array}{r}18 \\
5\end{array}$ & 0.98 \\
\hline $\begin{array}{l}\text { Housing }^{2} \\
\text { - specially adapted house/apartment for } \\
\text { senior citizens or elderly people } \\
\text { - ground-floor rooms } \\
\text { - regular house }\end{array}$ & 1 & $\begin{array}{l}14 \\
18\end{array}$ & $\begin{array}{r}6 \\
6 \\
6 \\
11\end{array}$ & 0.79 \\
\hline $\begin{array}{l}\text { Waiting period }{ }^{2} \\
-0 \text { - } 6 \text { months } \\
\text { - } 6 \text { - } 12 \text { months } \\
\text { - > over } 1 \text { year }\end{array}$ & - & $\begin{array}{l}12 \\
12 \\
17\end{array}$ & $\begin{array}{r}10 \\
6 \\
6\end{array}$ & 0.39 \\
\hline Level of physical limitation $(18-54)^{1,3}$ & 2 & 35 & 32 & 0.14 \\
\hline Personal perception of health ${ }^{1}(0-10)$ & 8 & 3.6 & 6.1 & 0.02 \\
\hline Loss of memory ${ }^{1}(0-6)$ & 9 & 3.3 & 3.1 & 0.73 \\
\hline Negative feelings ${ }^{1}(0-10)$ & 10 & 3.3 & 2.8 & 0.62 \\
\hline Feelings of loneliness ${ }^{1}(0-14)$ & 8 & 6.5 & 5.7 & 0.45 \\
\hline Social network ${ }^{1}(0-25)$ & 8 & 16.1 & 18.2 & 0.12 \\
\hline Social participation ${ }^{1}(4-20)$ & 1 & 8.2 & 9.3 & 0.36 \\
\hline Self-care agency ${ }^{1}(9-45)$ & 5 & 29.7 & 32.5 & 0.02 \\
\hline Urgency of admission $^{1}(1-5)$ & 2 & 4.0 & 1.6 & $<0.01$ \\
\hline
\end{tabular}

Note: ${ }^{1} \mathrm{ANOVA}$ (one-way), ${ }^{2} \mathrm{Chi}$-square, ${ }^{3}$ Only 60 people answered this part of the questionnaire, ${ }^{4} \mathrm{p} \leq 0.05$ 
Factors associated with the demand for admission into a home for the elderly

Because of the limited number of respondents, it was not possible to include all variables in the regression model in order to predict the demand for admission into a home for the elderly. Therefore, the variables were first explored univariately to ascertain whether a linear model was appropriate for describing the relationship and to identify possible outliers that might distort results. Then, five independent variables - age, social network, personal perception of health status, level of physical limitation, self-care agency - were included in the regression model. The dependent variable was the acceptance or refusal of an offer to be admitted into a home for the elderly (yes, I would accept such an offer,' 'no, I would refuse such an offer').

The regression analysis showed that respondents who would immediately accept an offer of admission had a limited social network and experienced more physical limitations in everyday activities (see Table 4). The more satisfactory the social network (defined as having good relationships with children, neighbours and relatives, and feeling provided for if sudden problems occur), the smaller the chance (OR 0.80; 95\% CI 0.65-0.98) that they would accept such an offer. In terms of the extent of physical limitations, it was found that the chance of acceptance becomes higher as physical limitations increase (OR 1.13; 95\% CI $1.00-1.27)$.

Table 4 Variables predicting whether elderly persons will accept or refuse an offer of admission into the home for the elderly of their first choice.

\begin{tabular}{|l|r|r|r|c|}
\hline \multicolumn{1}{|c|}{ Variables } & \multicolumn{1}{c|}{ B } & \multicolumn{1}{|c|}{ p-value $^{\mathbf{1}}$} & \multicolumn{1}{c|}{ OR } & \multicolumn{1}{c|}{ CI 95\% } \\
\hline Social network & -0.23 & 0.03 & 0.80 & $0.65-0.98$ \\
\hline Physical limitations & 0.12 & 0.05 & 1.13 & $1.00-1.27$ \\
\hline
\end{tabular}

${ }^{1} \mathrm{p} \leq 0.05$

\section{DISCUSSION AND CONCLUSION}

The results of this study show that the inability to manage everyday activities and the lack of a social network are strongly associated with elderly people's demand for residential care. Furthermore, this study clearly showed that waiting lists for homes for the elderly do not accurately reflect the demand for residential care, since $35 \%$ of the elderly people on a waiting list for residential homes did not actually experience an immediate demand for this type of care and stated that they would not accept an offer of admission into the home of their first choice. Before we discuss the findings of this study in more detail, some limitations of this study should be addressed. First, this study is explorative and used a crosssectional design. As a result, no definitive conclusions regarding causal relationships (predictors) can be made. Furthermore, the response rate was moderate $(40 \%)$. Although this is not unusual for this specific population [26], it undoubtedly has consequences for the generalisability of the findings. The 
demographic characteristics of the sample in this study are comparable with those of similar populations [27] and nation wide demographics [3]. However, the possibility of selection bias cannot be ignored. It seems possible that the study covered those elderly in best health, because 26 elderly people of the 163 prospective participants refused to participate due to poor health. This also might overestimate the share of those who were on the waiting list due to a sense of precaution. Future research should pay more attention to this problem of non-response.

The results contribute to the understanding of waiting lists and the demand for residential care. It became clear that not everybody who asks for admission into a home for the elderly, really needed it. This discrepancy puts a great burden on the health care system because elderly people who really need residential care are not receiving the care they want and are entitled to. Firstly, it should be prevented that a considerable proportion elderly Dutch citizens succeed in obtaining a place on a waiting list out of a sense of precaution in spite of a thorough and bureaucratic needs assessment procedure. The assessment agencies should pay more attention to incorporating the views of the elderly people into the assessment procedure and pay explicit attention to underlying motives for registering for this type of care and available resources. Secondly, elderly people should be well informed about what to do when problems become aggravated, especially because the waiting period for admission can be quite long [26]. Thirdly, it seems worthwhile to assess the needs, availability of resources and the demands of elderly persons repeatedly even when they are still on a waiting list because these factors often fluctuate over time, due to illness, recovery or other circumstances. For instance, elderly people often opt to register for residential care after grave health problems, for example CVA or fractures due to falls. Some of them recover and then no longer perceive the need to move to a home for the elderly. Nevertheless, most of them never take action to have their names removed from the waiting list. Finally, the contamination of waiting lists should be tackled in the near future to get a more realistic idea of the numbers of people waiting for residential care. It became clear from contacting the elderly that a considerable number of elderly people registered on a waiting list were already admitted into a home for the elderly or deceased $(\mathrm{n}=22)$. Another 15 could not reached due to administrative problems, very likely caused by death or moving house. This means that $19 \%$ of the elderly people we approached were in fact no longer waiting.

The results of this study also indicate that the availability of resources like social network and ability to manage daily activities play a significant role in predicting elderly people's demand for residential care. According to the model presented earlier (Figure 1) these factors could be predictors for the demand for residential care, and as a result are of importance for the development of adequate health care services. However, it should be stressed that the present study was cross-sectional. Furthermore, the study only examined a few resources 
in relation to the need for residential care due to a low number of cases. Therefore, future longitudinal research is needed and should focus on more cases and other possible resources in relation to the elderly people's demand for residential and other types of care, like the amount of social participation, living arrangement/housing, existence of informal care, material resources, transportation [14,28-37]. This also holds true for the operationalization of other components of the model, and relation between concepts.

\section{REFERENCES}

1. Stevens JAM, Lalleman AW, Mathijssen AW, Van Eijk W. Zorg in Limburg: De AWBZ -sector in kaart gebracht (Care in the Southern part of the Netherlands. An overview of the sector Care and Nursing). Maastricht: Universitaire Pers Maastricht 2000.

2. Vliegenthart M. Voortgang wachtlijstaanpak V\&V sector. Progression concerning the solution of waiting list problems in the sector Care and Nursing). Den Haag: Ministry of Health, Welfare and Sport (VWS) 2002.

3. De Klerk MMY. Rapportage ouderen 2001. Veranderingen in de leefsituatie (Report elderly people 2001. Changes in social situation). Den Haag: Social and Cultural Planning Office of the Netherlands (SCP) 2001.

4. Rosenberg M, Everitt J. Planning for aging populations: inside or outside the walls. Progress in Planning 2001, 56:199-168.

5. IJland CM. Eerste resultaten wachtlijstinventarisatie Sector Verpleging \& Verzorging. Peildatum 1 november 2002 (First results inventory waiting lists, reference date 1 November 2003). Taskforce Wachtlijsten 2003.

6. Gibler KM, Moschis GB, Lee E. Planning to move to retirement housing. Financial Services Review 1998, 7:291-300.

7. Aro A, Noro A, Salinto M. Deinstitutionalization of the elderly in Finland 1981-91. Scandinavian Journal Social Medicine 1997, 25:136-143.

8. Ministry of Health Welfare and Sport, Choosing with Care. The equipping of patients and consumers in a demand driven care sector. International Publication Series Health, Welfare and Sport no 13. Den Haag: Ministry of Health Welfare and Sport (VWS) 2002.

9. Lewis JS. Housing and social support needs of elderly persons: a need assessment in an independent living facility. Evaluation and Program Planning 1997, 20:269-277.

10. Splann Krothe J: Giving voice to Elderly People. Community-Based Long Term Care. Public Health Nursing 1997, 14:217-226.

11. Van Bilsen PMA, Hamers JPH, Groot W, Spreeuwenberg C. Welke zorg vragen ouderen? Een invenatrisatie (What care do elderly people ask for? An overview). Maastricht: Universitaire Pers Maastricht 2002.

12. Van Campen C, Woittiez I.B. Client demands and the allocation of home care in the Netherlands. A Multinomial logit model of client types, care needs and referrals. Health Policy 2003, 64:229-241. 
13. Council for Public Health and Health Care. De wensen van zorgclienten in Europa (The wants of care consumers in Europe). The Hague: Council for Public Health and Health Care (RVZ) 2003.

14. Lilja M, Borell L. Elderly People's Daily Activities and Need for Mobility Support. Scandinavian Journal of Caring Sciences 1997, 11:73-80.

15. Bandura A. Self-efficacy: The exercise of control. New York: Freeman 1997.

16. Maslow A. Motivation and personality. New York: Harper \& Row 1954.

17. Sheldon KM, Elliot AJ, Kim Y, Kasser T. What is Satisfying about Satisfying events? Testing 10 Candidate Psychological Needs. Journal of Personality and Social Psychology 2001, 80:325-339.

18. Freud S. Beyond the pleasure principle. London: Hogarth 1920.

19. Meijer A. Nursing homes in Europe: a comparative study of the organization and financing of nursing bomes in five European countries. Wageningen, Wageningen Agricultural University 1998.

20. Ministry of Health Welfare and Sport. Zorgindicatiebesluit; Besluit van 2 oktober 1997, houdende regels met betrekking tot werkterrein, de samenstelling en werkwijze van indicatieorganen (Care needs Assessment Decree; White Paper of October, 2 1997, regarding fields of activities, the formation, and the operation of Regional Needs Assessment Agencies). Staatsblad van het Koningrijk der Nederlanden 1997.

21. Maarse H, Van der Made J Cost containment and the right to health care. European Journal of Public Health 1998, 8:119-126.

22. Kempen GIJM, Doeglas DM, Suurmeijer TPBM. Het meten van problemen met zelfredzaambeid op verzorgend en buishoudelijk gebied met de Groningen Activiteiten Restrictie Schaal (GARS): een handleiding (The measurement of functional status on personal and domestic care by the Groningen Activity Restriction Scale: a manual). Groningen: Noordelijk Centrum voor Gezondheidsvraagstukken, Rijksuniversiteit Groningen 1993.

23. Van Linschoten, CP, Gerritsen JC, Romijn C: De schaal Subjektief Welzijn nader onderzocht (The Scale Subjective Welfare studied closer). Tijdschrift voor Gerontologie en Geriatrie 1993, 24:57-65.

24. Brouns G, Evers GCM, Smeets H, Isenberg M, Philipsen H. Appraisal of selfcare agency scale. Maastricht 1988.

25. Nunnally JCJ. Psychometric Theory. 2e ed. New York: McGraw-Hill 1978.

26. Caris-Verhallen WMCM, Kerksta A. Continuity of care for patients on a waiting list for institutional long-term care. Health and Social Care in the Community 2001, 9:1-9.

27. Van Eijk LM, Miedema I. Ouderen op de wachtlijst nader bekeken. Een onderzoek onder ouderen op de wachtlijst voor een verzorgingshuis in Oost-Groningen (A closer look. on elderly people at a waiting list for residential care in East Groningen). Groningen: Provinciaal Ontwikkelingsinstituut Zorg en Welzijn (POZW) 2001.

28. Crets S. Determinants of the use of ambulant social care by the elderly. Social Science and Medine 1996, 43:1709-1720. 
Chapter 3

29. Bass D, Looman W, Ehrlich P: Predicting the volume of health and social services: integrating cognitive impairment into the modified Andersen framework. The Gerontologist 1992, 32:33-43.

30. Brandenburg $H$. Welche Faktoren beeinflussen die Nutzung sozialer Dienste bei Alteren Menschen (Factors influencing the utilization of social services in old age). Pflege 1998, 11:5-10.

31. Calsyn RJ, Winter JP: Predicting four types of service needs in older adults. Evaluation and Program Planning 2001, 24:157-166.

32. Kempen GIJM and Suurmeijer PBM: Factors influencing professional home care utilization among the elderly. Social Science and Medine 1991, 32:77-81.

33. Kempen GIJM, Sonderen FLP: Individuele determinanten van gebruik van professionele en informele thuiszorg (Determinants of professional and informal home care use). In: Dagelijks functioneren van ouderen. Edited by Kempen GIJM, Ormel J, Assen, Van Gorcum 1996.

34. Linden M, Horgas AL, Gilberg R, Steinhagen-Thiessen, E. Predicting health care utilization in the very old. Journal of Aging and Health 1997, 9:3-27.

35. Stoddard H, Whitley E, Harvey I, Sharp D. What determines the use of home care services by elderly people. Health and Social Care in the Community 2002, 10:348-360.

36. Tomiak M, Berthelot J, Guimond E, Mustard CA: Factors associated with nursing-home entry for elders in Manitoba, Canada. Journal of Gerontology: MEDICAL SCIENCES 2000, 55a:M279-M287.

37. Algera M. Al you need is . . . home care. Matches between bome care needed, indicated and delivered; a study among chronic patients. Maastricht: Universiteit Maastricht 2004. 
Demand of elderly people for residential care 
THE USE OF COMMUNITY-BASED SOCIAL SERVICES BY ELDERY AT RISK FOR INSTITUTIONALIZATION: A SURVEY

PMA van Bilsen, JPH Hamers, AAM Don, W Groot \& C Spreeuwenberg Submitted 2007 


\section{ABSTRACT}

The purpose of this study is to examine the use of community-based social services set up in addition to regular home care facilities to support elderly people at risk of institutionalization who expressed a preference to remain at home.

Structured interviews were held with 334 elderly people at risk of institutionalization in two regions located in the Netherlands. Use of community-based social services was measured as participating in at least one social service. Bivariate and multivariate logistic regression models were developed to compare the users of social services with the non-users, controlling for personal and health related characteristics like functional status, subjective well-being, feelings of loneliness, autonomy and quality of life.

Two hundred and ninety-two elderly people out of the 334 elderly at risk of institutionalization (80 men, 212 women, mean age 83.4) specifically indicated that they would prefer to remain at home if community-based care and services were available. The use of social services was moderate to poor, with the exception of social, cultural and creative activities, restaurant facilities and individual counselling. Eldery people who lived in a sheltered environment (OR 2.53 ) or were supported by informal caregivers (OR 1.98) or who visited day care (OR 4.76) had a significantly higher probability of using community-based social services.

More attention should be given to the nature and accessibility of social services. The study has shown that informal care, day care facilities and sheltered accommodations have a positive impact on the use of social services. 


\section{INTRODUCTION}

As the majority of older people in western countries desire to live in their own home as long as possible, and with the costs of institutional care rapidly increasing, policies and services are focusing more and more on the community rather than on institutions as the primary axis of long-term care [1-5]. Consequently, an increasing number of community-based services are being set up. The precise nature of these services varies, but most programmes involve some combinations of in-home care (household activities, personal care, home nursing, companion services), day care activities, and social and supplementary services (e.g., distance-based health care, meals or transport facilities [4, 6-10]. These community-based care packages are delivered to eldery living independently and are intended to support them in their activities of daily living.

Although the community-based services have become available, their availability does not imply actual use [4]. Factors related to the use of suitable services are: perceived need, knowledge, availability (e.g., waiting lists), accessibility as defined by service attractiveness, acceptability, attitudes toward service use, severity of the disabilities, patterns of self-care and the ability to cope with changing circumstances [11-16]. With regard to the use of community-based social services specifically, Walker et al. (1998) concluded that elderly people living in sheltered accommodations were more likely to use these services compared to those living independently in the community [17]. This difference could not be accounted for by greater disability and larger numbers of people living alone, which suggests that these services may preferably be allocated to elderly residing in sheltered accommodations. Fokkema \& Van Tilburg (2005) concluded that the availability of socially rich living environments or joint activities were not enough to encourage elderly people to really enjoy using these services [18]. Some of the important preconditions mentioned were relatively good health, sufficient income and basic social skills.

Following national policy aimed at developing and improving communitybased long-term care and services [19, 20], a coordinated package of community-based social services in addition to existing regular home care and day care, has been developed and implemented in two regions of the Netherlands. These services can be divided into counselling activities (individual or group counselling), provision of information (personal adviser), companion services (restaurant facility, telephone circle and buddy project), socio-cultural activities (e.g., cultural, sportive, creative activities) and services like home library service and administrative support. These services aim to serve elderly people who are 'at risk of institutionalization', but who express a preference for remaining at home if additional support were to be made available. 'At risk of institutionalization' means that these elderly - based on a uniform nationwide assessment device - are eligible for admission into homes for the elderly or care on demand (24 hours a day) [21, 22]. To encourage elderly people to make use of these social services, the costs of their participation were reimbursed by an 
extra government-sponsored financial contribution [20].

The primary aim of this study is to explore the use of community-based social services by elderly at risk of institutionalization who prefer to remain in the community. In considering this population 'at risk', their use of other forms of health care at home, both formal and informal, has also been studied. To understand the use of social services personal characteristics (e.g., age, housing, marital status), health-related characteristics (e.g., functional status, vitality, mobility) and subjective well-being were studied. The research questions were:

- Do users of community-based social services differ in terms of home care use and personal, health-related and well-being characteristics from those who do not use social services at all?

- Is there a relationship between social service use and diverse personal, health-related and well-being characteristics?

\section{METHODS}

Design

A cross-sectional study was conducted by interviewing elderly people.

\section{Subjects}

The managing directors of the homes for the elderly in two regions in the Netherlands selected elderly people (older than 65) who were at risk of institutionalization, but were living still living independently in the community $(\mathrm{n}=707)$. These elderly had made an official application for admission to a home for the elderly or care on demand (24 hours a day) with assessment agencies [21, $22]$. These agencies had positively evaluated the legitimacy of the client's request based on an objective needs assessment procedure. As a result, the selected elderly were registered on waiting lists for admission to the homes for the elderly. Data on exclusion are presented in the results section under 'sample'.

\section{Procedure and ethical considerations}

Written information about the study was sent to those elderly people selected. Information was given about the aim of the study, research method, procedure, anonymity with regard to data analysis, and a telephone number in case the elderly people required more information. Special attention was paid to the fact that participation was voluntary. A few days after this letter had been sent, they were contacted by telephone to ask whether they would like to participate. If they agreed, a date was set for an interview. Reasons for refusal were systematically recorded'.

No approval of an established medical ethical board was needed because the respondents were not subjected to procedures or required to follow rules of behaviour (Central Committee on Research Involving Human Subjects, known by the Dutch initials CCMO)[23]. 


\section{Study variables}

The use of social services was assessed by asking the respondents if they made use of the services set up in the region. All services - individual counselling, group counselling, personal adviser, restaurant facility, telephone circle, buddy project, socio-cultural activities, home library service and administrative support - were discussed during the interview. The respondents had to answer with a simple 'yes' or 'no'. In addition, the managing directors of the health care institutions were asked to register the social service use of their clients.

Aside from social service use the following variables were measured: use of (in)formal care and personal (age, gender, housing and marital status), healthrelated (functional status and accessibility problems in home and nearby area) and well-being characteristics (vitality, mental health, life satisfaction, loneliness, autonomy, feelings of security and quality of life). Selection of these variables was based on the model 'The relations between health care needs, resources and demands' $[5,15,24]$. This model will be explained in the discussion section.

With the exception of the self-developed measures 'autonomy', 'insecurity' and the mobility-scale, we used instruments that have been proven to have satisfying psychometric properties [25-30].

The use of (in)formal health care was assessed by asking the respondents whether they visited day care centres or were receiving assistance for housekeeping, personal or nursing care. Informal care was measured by the question: (1) Are you receiving assistance from informal caregivers?

Functional status was measured using the Groningen Activity Restriction Scale $[30,31]$. Respondents were asked to indicate to what extent they were still able to engage in the activities of daily living related to personal care (ADL) (eleven activities) and in those activities related to independent living, including preparing meals, shopping for groceries and performing light or heavy housework (IADL) (seven activities). The respondents had to answer on a threepoint ordinal scale to what extent they were able to carry out activities of daily living, ranging from performing them completely independently (score 1) to performing them only with help from others (score 3) (see Table 1).

The respondents' perceived accessibility problems in and outside the home and nearby area were assessed by means of five questions, in order to assess their mobility and functional impairment in terms of getting around. These questions were derived from the official assessment protocol of the assessment agency. The respondents had to answer on a three-point ordinal scale to what extent they had problems moving around inside and outside their house, using the bathroom, kitchen or toilet, in addition to the accessibility of public facilities like grocery shops, bus stops or banks $(0=$ no problem, $1=$ somewhat of a problem, $2=$ serious problem). Higher scores meant that the respondents experienced more problems with their housing and nearby residential area (see Table 1).

Subjective well-being consists of an affective, emotional component and a 
self-rated satisfaction with life. The affective component was measured with two subscales of the RAND-36 Health Survey (RAND-36): 'mental health' (five items) and 'vitality' (four items) [25, 26]. The respondents had to answer on a sixpoint ordinal scale to what extent they felt nervous, depressed, lively, tired, energetic or exhausted. The response categories varied from 'constantly' (score 1) to 'never' (score 6). These scores were transformed to a 100-point scale, with higher scores indicating greater perceived subjective well-being (see Table 1).

The respondents' opinions about life satisfaction were measured with the Satisfaction With Life Scale (SWLS) (five items) [27]. The respondents had to answer on a seven-point scale to what extent they agreed with propositions about life satisfaction like 'My life is ideal in most respects' or 'On the whole, I'm satisfied with my life'. Response options varied from 'I strongly disagree' (score 1), to 'I strongly agree' (score 7). Higher scores indicated a more positive perception of life satisfaction (see Table 1).

Loneliness was measured with the Rasch-type loneliness scale (eleven items) $[28,29]$. Respondents had to answer on a five-point ordinal scale to what extent they felt they lacked a special friend or company in general, or experienced feelings of loneliness and emptiness. The answers were then recoded resulting in a scale from 0 to 11 . Higher scores implied that the respondents experienced more feelings of loneliness (see Table 1)

Overall quality of life was assessed with one question on a Visual Analogue Scale (VAS). The respondents had to indicate their quality of life on a $100-\mathrm{mm}$ Visual Analogue Scale (VAS) (with '0' representing very low quality of life and '100' representing very high quality of life) (see Table 1). However, during data collection we found that the phrasing of this question and the accompanying request to put a mark on the VAS caused problems. In order to avoid too many missing values, we introduced an alternative assessment method for those elderly who were not able to put a mark on the VAS. These respondents were asked to give a report mark between 0 and 100 .

Autonomy and feelings of insecurity are very important aspects of quality of life for the elderly, especially when they become more disabled and fragile [5, 32, 33]. However, no valid and reliable instruments were available to measure these two aspects [32]. Therefore, ten self-developed items were added (six items about autonomy and four items about insecurity). These items were phrased on the basis of results of earlier research about elderly people's basic and care needs [5], and appear on the surface, therefore, to have face validity. Respondents had to answer on a five-point ordinal scale to what extent they felt dependent on others, were receiving care at the time when they wanted it and felt secure in their own home and social environment. The response categories were: 'Yes!', 'Yes', 'More or less', 'No' and 'No!'. A higher score meant that the respondents felt they were more independent from others and more secure (see Table 1).

Table 1 summarizes the characteristics of the above-mentioned measures (Cronbach's $\alpha$, range, sum scores, standard deviation). The measurement 
instruments proved to be internally consistent (with a Cronbach's $\alpha$ range based on the data of 0.67 to 0.89 ), except for feelings of insecurity (Cronbach's $\alpha=0.34)$ [34].

Table 1 Summary of the statistics of variables measured

\begin{tabular}{|c|c|c|c|c|c|c|}
\hline Domains & No. & Range & Alpha $^{1}$ & Mean & \multicolumn{2}{|c|}{ Meaning of scores } \\
\hline & & & & & Low & High \\
\hline $\begin{array}{l}\text { Functional } \\
\text { status }\end{array}$ & 18 & $18-54$ & 0.89 & $32.1(7.4)$ & $\begin{array}{l}\text { Seriously limited in } \\
\text { performing all types } \\
\text { of (I)ADL activities } \\
\text { independently }\end{array}$ & $\begin{array}{l}\text { Performing all types } \\
\text { of daily (I)ADL } \\
\text { activities without } \\
\text { help from others }\end{array}$ \\
\hline $\begin{array}{l}\text { Accessibility } \\
\text { of house } \\
\text { and nearby } \\
\text { area }\end{array}$ & 5 & $0-10$ & 0.67 & $1.7(1.9)$ & $\begin{array}{l}\text { No problems with } \\
\text { accessibility in their } \\
\text { home and nearby } \\
\text { area }\end{array}$ & $\begin{array}{l}\text { Great perceived } \\
\text { problems with } \\
\text { accessibility in their } \\
\text { home and nearby } \\
\text { area }\end{array}$ \\
\hline Well-being & & & & & & \\
\hline Vitality & 4 & $0-100$ & 0.76 & $57.8(17.3)$ & $\begin{array}{l}\text { Feeling tired and } \\
\text { worn out all of the } \\
\text { time }\end{array}$ & $\begin{array}{l}\text { Feeling full of zest } \\
\text { and energy all of } \\
\text { the time }\end{array}$ \\
\hline $\begin{array}{l}\text { Mental } \\
\text { health }\end{array}$ & 5 & $0-100$ & 0.77 & $68.9(16.1)$ & $\begin{array}{l}\text { Feeling nervous and } \\
\text { depressed all of the } \\
\text { time }\end{array}$ & $\begin{array}{l}\text { Feeling peaceful, } \\
\text { happy and calm all } \\
\text { of the time }\end{array}$ \\
\hline $\begin{array}{l}\text { Life } \\
\text { satisfaction }\end{array}$ & 5 & $5-35$ & 0.74 & $26.5(5.3)$ & $\begin{array}{l}\text { Low perceived life } \\
\text { satisfaction }\end{array}$ & $\begin{array}{l}\text { Having serious } \\
\text { feelings of } \\
\text { loneliness and } \\
\text { emptiness }\end{array}$ \\
\hline Loneliness & 11 & $0-11$ & 0.79 & $3.2(2.9)$ & $\begin{array}{l}\text { Having no feelings } \\
\text { of loneliness }\end{array}$ & $\begin{array}{l}\text { Having serious } \\
\text { feelings of } \\
\text { loneliness and } \\
\text { emptiness }\end{array}$ \\
\hline $\begin{array}{l}\text { Quality of } \\
\text { life }\end{array}$ & 1 & $0-100$ & - & $64.3(16.7)$ & $\begin{array}{l}\text { Very low quality of } \\
\text { life }\end{array}$ & $\begin{array}{l}\text { Very high quality of } \\
\text { life }\end{array}$ \\
\hline Autonomy & 6 & $6-30$ & 0.68 & $24.3(3.3)$ & $\begin{array}{l}\text { Perceiving } \\
\text { dependence on } \\
\text { others }\end{array}$ & $\begin{array}{l}\text { Not perceiving } \\
\text { dependence on } \\
\text { others }\end{array}$ \\
\hline Insecurity & 4 & $4-20$ & 0.34 & - & $\begin{array}{l}\text { Feelings of } \\
\text { insecurity }\end{array}$ & $\begin{array}{l}\text { Greater perceived } \\
\text { security }\end{array}$ \\
\hline
\end{tabular}

${ }^{1}$ Cronbach's Alpha 


\section{Statistical methods}

Statistical evaluation of the study aims began with descriptive analyses (frequencies, mean, deviation and sum scores), followed by bivariate analyses of outcome and control variables. Use of community-based social services was measured as participating in at least one social service. Differences between respondents using social services and those who did not use any social service at all were investigated using the chi-square test for variables at a dichotomous level and One-way Anova for variables at an interval and ratio level.

A multivariate logistic model was developed to explore the association between the variables measured concerning social service use. Only those characteristics that had a statistically significant bivariate association $(p<0.05)$ with social service use were included in the model. The odds ratios (OR) and corresponding $95 \%$ confidence intervals (CI) derived from the model are effect estimates simultaneously adjusted for other factors in the model.

\section{RESULTS}

\section{Sample}

A considerable proportion of the selected elderly $(n=707)$, were never reached because there was no answer after prolonged attempts $(n=61)$, or because they showed no interest and consequently refused to participate $(n=161)$. Figure 1 presents a chart of the recruitment strategy. Another 82 persons claimed to be too sick, confused or disabled (e.g., because of hearing and vision problems) to participate. Eventually, 334 interviews were conducted (response rate of 47.2\%). With regard to the research questions we excluded another 17 respondents because they had moved into homes for the elderly in the meantime and 25 respondents, who specifically pointed out preferring admission into a home for the elderly and no longer wanting to live independently in the community. Unfortunately no background information was available about the selected elderly people we were not able to contact and the non-responders.

Figure 1 Recruitment strategy

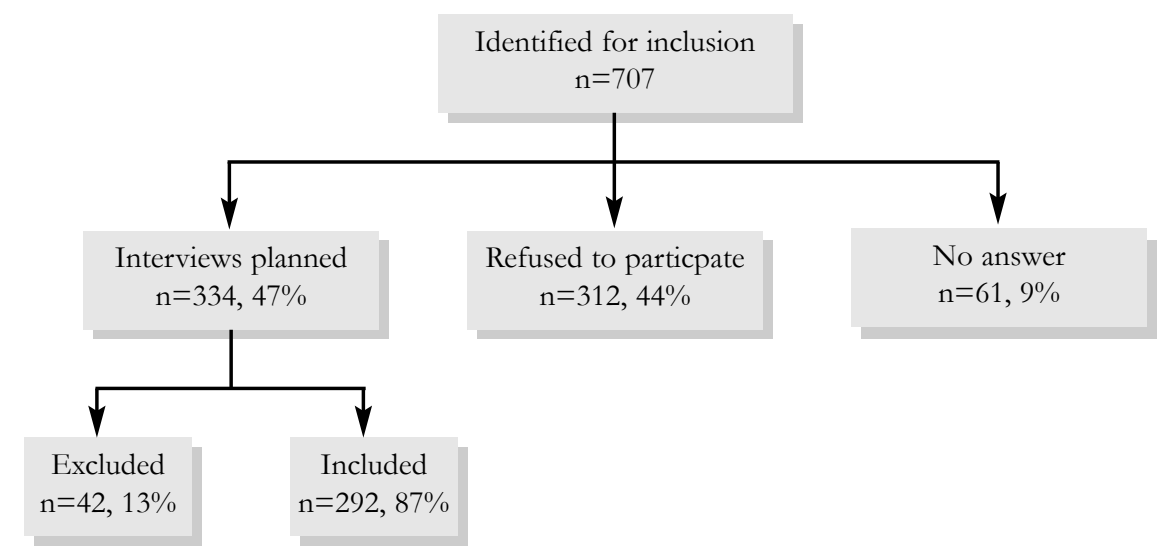


The sample thus consisted of 292 elderly ( 80 men and 212 women). Their mean age was 83.4 years $(\mathrm{SD}=5.9$, range 65-97). Two hundred and thirty-one respondents were living on their own, while 61 respondents were living with someone else, such as a partner $(n=50)$, children $(n=5)$ or others $(n=6)$. One hundred and seventy respondents (58.2\%) were living in ground-floor apartments fully adapted for elderly people (sheltered accommodations). Another 53 respondents were living in single-storey houses with only groundfloor rooms but no other adaptations, and 69 respondents were living in a nonground-floor apartment or a regular house with a first and second floor (without a lift to get to the second floor).

\section{Use of home care and social services}

With the exception of 12 people (4.1\%), 279 respondents $(95.9 \%)$ were receiving some kind of care, that is, household support, personal care, nursing care or day care. The majority of the respondents $(n=261,89.4 \%)$ were receiving household support, and 161 respondents (55.1\%) were receiving personal care. Nursing care $(n=102 ; 34.9 \%)$ and day care $(n=44 ; 15.1 \%)$ were used less frequently. 190 respondents $(65.3 \%)$ were receiving more than one type of service in contrast to $89(30.6 \%)$ respondents who were only receiving assistance for one type of care, mostly household support. The combination of household support and personal care was most common ( $n=69 ; 25.2 \%$ ) (see Table 2 ).

Table 2 Different types of home care combined $(n=292)^{1,2}$

\begin{tabular}{|l|r|}
\hline Combinations of different types of formal care & n (\%) \\
\hline Household support & $78(28.0)$ \\
\hline Household support + personal care & $69(25.2)$ \\
\hline Household support + personal care + nursing & $54(18.0)$ \\
\hline Household support + nursing & $23(7.3)$ \\
\hline Household support + personal care + day care & $14(5.4)$ \\
\hline Household support + personal care + nursing + day care & $13(4.4)$ \\
\hline Household support + day care & $8(3.2)$ \\
\hline Personal care & $5(1.6)$ \\
\hline Personal care + nursing + day care & $3(0.9)$ \\
\hline Day care & $3(0.9)$ \\
\hline Personal care + nursing & $3(0.9)$ \\
\hline Nursing & $3(0.9)$ \\
\hline Household support + nursing + day care & $2(0.6)$ \\
\hline Nursing + daycare & $1(0.3)$ \\
\hline
\end{tabular}

${ }^{1} 12$ respondents $(4.1 \%)$ did not receive any formal care at all

${ }^{2}$ The data of one person with regard to home care were missing 
The majority of the respondents $(n=196,67.6 \%)$ were receiving informal care, mostly provided by a son or daughter or a son- daughter-in-law.

With regard to the use of social services, the data of five respondents $(1.7 \%)$ were systematically missing. Of the remaining respondents $(n=287), 195$ respondents indicated that they made use of at least one social service (67.9\%). The most frequently used services in both regions were socio-cultural activities $(51.7 \%, \mathrm{n}=148)$ and restaurant facilities $(21.7 \%, \mathrm{n}=62)$ (Table 3). Individual care by a social worker was used by $30.9 \%$ of the elderly in the Limburg region. Over $14 \%$ of the elderly $(n=41)$ participated in the buddy project, meaning that volunteers visited these clients once a week. Thirty-nine elderly people (13.6\%) were informed by a personal adviser about elderly facilities, services, activities and so on. Administrative assistance, group counselling and telephone circle were used by less than $6 \%$ of the respondents.

Compared to the answers of the respondents, the formally recorded use of social services was considerably lower. This discrepancy is clearly shown in Table 3 (final column). Services other than social, cultural and creative activities $(44.1 \%)$ and restaurant facilities $(10.4 \%)$ were used by less than $5 \%$ of the respondents. Some services (group counselling, home library service and administrative assistance) were not used at all according to the registration of the caregivers.

Table 3 Community-based social services according to the respondents and their caregivers $(\mathrm{n}=292)$

\begin{tabular}{|c|c|c|}
\hline & $\begin{array}{c}\text { Respondents }^{1} \\
\mathrm{n}=286(\%)\end{array}$ & $\begin{array}{l}\text { Caregivers }^{2} \\
n=288(\%)\end{array}$ \\
\hline Individual care by social worker* & $34(30.9)$ & $1(0.9)$ \\
\hline Group counselling by social worker* & $6(5.5)$ & $0(0.0)$ \\
\hline Social, cultural and creative activities & $148(51.7)$ & $127(44.1)$ \\
\hline Restaurant facilities & $62(21.7)$ & $30(10.4)$ \\
\hline Personal adviser & $39(13.6)$ & $10(3.5)$ \\
\hline Home library service* & $10(9.1)$ & $0(0.0)$ \\
\hline Telephone circle & $4(1.4)$ & $9(3.1)$ \\
\hline Buddy project & $41(14.3)$ & $12(4.1)$ \\
\hline Administrative assistance* & $6(5.5)$ & $0(0.0)$ \\
\hline
\end{tabular}

${ }^{1}$ The data of five respondents on their use or non-use of social service were missing

${ }^{2}$ The caregivers did not have data with regard to four respondents

*These services have only been set up and assessed in the Limburg region $(n=110)$. 
Relationship between the use of community-based social services and demographic, health and well-being characteristics

Bivariate relationships between social service use and demographic, health and wellbeing characteristics are shown in Table 4. The association between social service use and living condition, housing, informal care, day care, problems with housing and nearby environment, and functional status (especially IADL), was statistically significant. Users of social services were more likely to live alone $(p=0.027)$ or in a sheltered accommodation $(p=0.002)$. Users of social services received informal care more often $(p=0.024): 71.6 \%$ of the respondents who used social services had an informal caregiver as compared to $58.2 \%$ of the nonusers. Users of social services and non-users received similar assistance in housekeeping, personal care or nursing. However, users of social services were more likely to visit day care facilities as compared to non-users $(p=0.004)$. Furthermore, users of social services experienced fewer functional limitations in everyday activities $(\mathrm{p}=0.021)$. Non-users especially were less able to engage in activities related to independent living (e.g., preparing meals, shopping for groceries) $(\mathrm{p}=0.015)$. In addition, users of social services had fewer problems with their housing and nearby area $(\mathrm{p}=0.005)$.

After examining these relationships, only those variables that had a bivariate association $(\mathrm{p} \leq 0.05)$ with social service use were included in a logistic regression model to examine the individual contribution of the predictors. The results showed that living in a sheltered accommodation (OR 2.53), the availability of informal care (OR 1.98) and visiting day care (OR 4.76) were the most important determinants of social service use (Table 4). 
Table 4 Users of community-based social services compared with non-users ( $\mathrm{n}=287)$

\begin{tabular}{|c|c|c|c|c|c|}
\hline \multirow[t]{2}{*}{ Characteristics of the respondents } & $\begin{array}{c}\text { Use } \\
n=215\end{array}$ & $\begin{array}{c}\text { Non-use } \\
n=96\end{array}$ & p-value & $\mathbf{O R}^{3}$ & $95 \% \mathrm{CI}$ \\
\hline & \multicolumn{3}{|c|}{ Bivariate analyses } & \multicolumn{2}{|c|}{ Logistic regression } \\
\hline Age $(\mathrm{SD})^{1}$ & $83.5(\operatorname{sd} 5.6)$ & $83.1(\mathrm{sd} 6.6)$ & 0.596 & - & - \\
\hline Gender $^{2}$ (female) & $142(72.8 \%)$ & $66(71.7 \%)$ & 0.848 & - & - \\
\hline Living condition ${ }^{2}$ (alone) & $162(83.1 \%)$ & $66(71.7 \%)$ & 0.027 & ns & ns \\
\hline Housing $^{2}$ (sheltered) & $127(65.1 \%)$ & $42(45.7 \%)$ & 0.002 & 2.53 & $1.44-4.45$ \\
\hline Informal care ${ }^{2}$ (yes) & $139(71.6 \%)$ & $53(58.2 \%)$ & 0.024 & 1.98 & $1.12-3.51$ \\
\hline Household assistance $^{2}$ (yes) & $175(90.2 \%)$ & $83(90.2 \%)$ & 0.901 & - & - \\
\hline Personal care ${ }^{2}$ (yes) & $106(54.4 \%)$ & $55(59.8 \%)$ & 0.388 & - & - \\
\hline Nursing $^{2}$ (yes) & $74(37.9 \%)$ & $28(30.8 \%)$ & 0.238 & - & - \\
\hline Day care ${ }^{2}$ (yes) & $38(19.5 \%)$ & $6(6.5 \%)$ & 0.004 & 4.76 & $1.81-12.54$ \\
\hline $\begin{array}{l}\text { Functional Status (GARS) }(18-54)^{1} \\
\text { ADL } \\
\text { IADL }\end{array}$ & $\begin{array}{l}31.5(7.0) \\
17.1(4.2) \\
14.5(3.5)\end{array}$ & $\begin{array}{l}33.7(8.1) \\
18.1(5.0) \\
15.6(3.7)\end{array}$ & $\begin{array}{l}0.021 \\
0.061 \\
0.015\end{array}$ & $\begin{array}{r}\text { ns } \\
- \\
\text { ns }\end{array}$ & $\begin{array}{l}\text { ns } \\
\text { ns }\end{array}$ \\
\hline $\begin{array}{l}\text { Accessibility of house and nearby area } \\
(0-10)^{1}\end{array}$ & $1.5(1.8)$ & $2.2(2.2)$ & 0.005 & ns & ns \\
\hline Vitality $(0-100)^{1}$ & $58.3(17.5)$ & $56.4(17.4)$ & 0.390 & - & - \\
\hline Mental health $(0-100)^{1}$ & $68.2(16.5)$ & $70.2(15.6)$ & 0.316 & - & - \\
\hline $\begin{array}{l}\text { Opinion about life satisfaction }{ }^{1} \\
(5-35)\end{array}$ & $26.4(5.1)$ & $26.5(6.0)$ & 0.796 & - & - \\
\hline Feelings of loneliness $(0-11)^{1}$ & $3.2(2.9)$ & $3.1(3.0)$ & 0.740 & - & - \\
\hline Perceived autonomy $(6-30)^{1}$ & $24.2(3.1)$ & $24.4(3.7)$ & 0.124 & - & - \\
\hline Quality of life $(0-100)^{1}$ & $65.3(15.7)$ & $61.5(18.7)$ & 0.087 & & - \\
\hline
\end{tabular}

${ }^{1} \mathrm{~T}$-Test, ${ }^{2} \mathrm{Chi}$ square, ${ }^{3} \mathrm{p} \leq 0.05$

\section{DISCUSSION AND CONCLUSION}

The use of most community-based social services appears to be moderate according to the respondents and even poor, given the registration of the formal caregivers. Individual care, social-cultural activities and restaurant facilities were the most frequently used services. The six remaining services were - according to the answers of the respondents - used by less than $15 \%$ of the elderly, of which three services (group counselling, telephone circle and administrative 
assistance) were used by even less than $6 \%$ of the respondents. According to the registration of the caregivers, three services (group counselling, home library service and administrative assistance) were not used at all. Group comparison shows that users of social services were less impaired than non-users. Users were more capable to performing activities of daily life and experienced fewer mobility problems in and around the house. Above all, users of social services received informal care and day care more often, and were more likely to live in a sheltered accommodation.

This study has some limitations First, the study used a cross-sectional design. As a result, no definitive conclusions regarding causal relationships can be drawn. Second, the response rate was moderate (47\%). Although this is not unusual for this specific population [35], the reasons for non-response present a reasonable doubt that selection bias might have been a problem. It is quite possible that the respondents were the relatively healthier part of the 707 people eligible for inclusion. However, it must be remembered that all elderly people selected to participate in this study were 'at risk of institutionalization' based on their functional impairments. Besides, the main goal of this study was to examine the differences between elderly people who used social services and those who did not use social services at all. Third, the measurements for assessing autonomy and feelings of insecurity were self-developed. The scale 'autonomy' proved to be internally consistent (reliability), and is expected to have face validity. The scale 'insecurity', however, was not internally consistent. Consequently, the results with regard to autonomy and insecurity should be interpreted with caution. Future research should address ways of assessing both concepts in a valid and reliable way, especially because staying independent is a driving force for many elderly people and feelings of insecurity have proven to be a major issue in general well-being [36]. Fourth, more attention should be paid to the measures 'accessibility of house and nearby area' and 'quality of life'. The measure 'accessibility' seems to be a reliable measure, however, no further information about psychometric properties was available. In future, it would seem advisable to use a more easily manageable measure for quality of life.

The predominant finding of this study was that the use of community-based social services was very moderate to poor. This raises the question of whether elderly people at risk of institutionalization do have a perceived need for these social services. Based on the results of this study, one recommendation might be that the desirability of these specific services should be reconsidered. The recently presented model 'The Relations between health care needs, resources and demands' $[5,15,24]$ could be a helpful tool when reconsidering the nature of the services offered. This model has been specifically developed in order to create demand-driven client-centred services to satisfy clients' need and preferences. According to this model the resources of persons (e.g., mobility, 
informal care, self-care agency and housing) are paramount in the development of services and service use. Resources are defined as circumstances or means which enable and support elderly people in fulfilling their basic needs (e.g., need for autonomy, safety, social life and leisure). Consequently, a need for care or support is a result of insufficient resources being available. (Health care) services should, therefore, primarily support older people's resources, such as their mobility, so they can attend their preferred activities.

If elderly people at risk of institutionalization indeed have a perceived need for these specific services, barriers to using these services need to be studied. The comparison between the users and non-users of social services reveals some factors, which are obviously related to the accessibility and approachability of social services, on the one hand, and the capability of the elderly persons to use them, on the other. The fact that social activities are usually organized at community centres or day care centres linked to sheltered living facilities increases the accessibility of these activities for elderly people living in such facilities. This explains why sheltered living respondents were more likely to use social services than were those living in regular houses. This finding is in line with earlier results of Walker et al. (1998) [17]. We also found that users of social services were less functionally impaired and inconvenienced by inadequate accessibility of in their house and nearby area. This may be an indication that users of social services perceive fewer (physical) barriers to using social services. The finding that elderly people who receive informal care were more likely to participate in social services is probably related to this accessibility issue as well. The involvement of informal caregivers may mean that elderly persons were better informed about the services, and were more stimulated and enabled to access them (e.g., transport).

We found a considerable discrepancy between the social service use reported by the respondents themselves and the use recorded by the caregivers. One explanation might be that the respondents did not distinguish between community-based social services recently introduced in the region and regular community centre work or activities organized by associations they are members of (e.g., senior citizens' associations). In addition, day care activities were often quite similar in content to activities organized as part of the community-based social services. The formal caregivers only recorded the use of the 'new social services' in the region and were not aware of the use of social services for the elderly 'outside' the health care sector. In this sense, the newly introduced community-based social services seem to offer limited added value to already existing social facilities in the community.

Finally, considering their limited use it is not very likely that the social services studied have distinctive added value in enabling elderly people at risk of institutionalization to age in place. This is a worrying finding that should be seriously taken into account when planning community-based social services in the future. 


\section{REFERENCES}

1. Gibler KM, Moschis GP, Lee E. Planning to move to retirement housing. Financial Services Review 1998, 7:291-300.

2. Rosenberg M, Everitt J. Planning for aging populations: inside or outside the walls. Progress in Planning 2001, 56:199-168.

3. Rauner MS, Vissers JMH. OR applied to health services: Planning for the future with scarce resources. European Journal of Operational Research 2003, 150:1-2.

4. Cox CB. Community Care for an Aging Society. Issues, Policies and Services. New York: Springer Publishing Company, Inc. 2005.

5. Van Bilsen PMA, Hamers JPH, Groot W, Spreeuwenberg C. Welke zorg vragen ouderen? Een inventarisatie (What care do elderly people ask for? An overview). Maastricht: Universitaire Pers Maastricht 2002.

6. Greene VL Do Community-Based Long-Term-Care Services Reduce Nursing Home Use? A Transition Probability Analysis. The Journal of Human Resources 1993, 28:297-317.

7. Gaugler JE, Kane RL, Kane RA, Newcomer R: Early Community-Based Service Utilization and Its Effects on Institutionalization in Dementia Caregiving. The Gerontologist 2005, 45:177-185.

8. Borgenicht K, Carty E, Feigenbaum LZ. Community Resources for Frail Older Patients. The Western Journal of Medicine 1997, 67:291-294.

9. Plochg T, Klazinga S. Community-based integrated care: myth or must? International Journal for Quality in Health Care 2002, 14:91-101.

10. Duke C. The frail elderly community-based case management project. Geriatric Nursing 2005, 26:122-127.

11. Andersen R, Newman JF. Societal and individual determination of medical care utilization in the United States. Milbank Memorial Fund Quarterly 1973, 51:95-124.

12. Wallace S. The no-care zone: Availability, accessibility, and acceptability in community based long term care. The Gerontologist 1990, 30:254-262.

13. Yeatts D, Crow T, Folts E. Service use among low-income minority elderly: Strategies for overcoming barriers. The Gerontologist 1992, 32:24-31.

14. Norburn J, Bernard S, Konrad T, Woomert A, De friese G, Kalsbeek W, Koch G, Ory M. Selfcare and assistance from others in coping with functional status limitations among a national sample of older adults. Journal of Gerontology, Social Sciences 1995, 50B:S101-S109.

15. Van Bilsen PMA, Hamers JPH, Groot W, Spreeuwenberg C. Demand of elderly people for residential care: an exploratory study. BMC Health Services Research 2006, 6(39).

16. Schoenberg N, Coward R. Residential differences in attitudes about barriers to using community-based services among older elderly. J Rural Health 1998, 14:295-304.

17. Walker M, Orrell M, Manela M, Livingston G, Katona C. Do health and use of services differ in residents of sheltered accommodation? A pilot study. International Journal of Geriatric Psychiatry 1998, 13:617-624.

18. Fokkema T, Van Tilburg T. Eenzaam en dan? De (on)mogelijkheden van interventies bij ouderen (Loneliness and then what? The (im)possibilities of interventions by elderly people). Beverwijk: Stichting Sluyterman van Loo, 2005.

19. Ross-van Dorp C. Extramuralisering in relatie tot de modernisering van de AWBZ en 
Chapter 4

boumproblematiek intramurale zorg (Transformation of institutions into independent dwellings in relation to the Exceptional Medical Expenses Act and intramural care).The Hague: Ministry of Health Welfare and Sport (VWS) 2003.

20. Ross-van Dorp C. Subsidieregeling diensten bij wonen met zorg (Government-sponsored financial contribution for housing and care). The Hague: Ministry of Health Welfare and Sport (VWS) 2003.

21. Ministry of Health, Welfare and Sport. Zorgindicatiebesluit; Besluit van 2 oktober 1997, houdende regels met betrekking tot werkterrein, de samenstelling en werkwijze van indicatieorganen (Care Needs Assessment Decree; White Paper of October, 2, 1997, regulating the activities, formation and mode of operation of Regional Needs Assessment Agencies). Staatsblad van bet Koningrijke der Nederlanden 1997, Sdu 447.

22. National Council for Public Health. Indicatiestelling en zorg op maat: advies van de Nationale Raad voor de Volksgezondheid en het College voor Ziekenbuisvoorzieningen (Needs assessments and customised care: recommendations by the National Council for Public Health and the Council for Hospital Facilities). Zoetermeer: National Council for Public Health, 1994.

23. Central Committee on Research Involving Human Subjects (known by the Dutch initials CCMO). Retrieved from www.ccmo.nl

24. Hamers JPH, Van Bilsen PMA. The care of the elderly in nursing settings - are those cared for getting what they need? In: Proceedings of the 2nd World Ageing and Generations Congress. Edited by Sousa-Poza A. St. Gallen: World Demographic Association 2006.

25. Van der Zee KI, Sanderman R. Het meten van de algemene gezondheidstoestand met de RAND-36: een handleiding (Measuring bealth with the RAND-36: a manual). Groningen: Noordelijk Centrum voor Gezondheidsvraagstukken (NCG) 1993.

26. Moorer P, Suurmeijer PBM, Foets M, Molenaar IW. Psychometric properties of the RAND36 among three chronic diseases (multiple sclerosis, rheumatic diseases and COPD) in the Netherlands. Quality of Life Research 2001, 10:637-645.

27. Diener E, Emmons RA, Larsen RJ, Griffin S. The satisfaction with life scale. Journal of Personality Assessment 1985, 49:71-75.

28. De Jong-Gierveld J, Kamphuis F. The development of a Rasch-type loneliness scale. Applied Psychological Measurement 1985, 9:289-299.

29. De Jong-Gierveld J, Van Tilburg T. Manual of the Loneliness Scale. Retrieved from http//home.scw.vu.nl/ tilburg/manual_loneliness_scale_1999.html.

30. Kempen GIJM, Miedema I, Ormel J, Molenaar W. The assessment of disability with the Groningen Activity Restriction Scale. Conceptual framework and psychometric properties. Social Science \& Medicine 1996, 43:1601-1610.

31. Kempen GIJM, Doeglas DM, Suurmeijer TPBM. Het meten van problemen met zelfredzaambeid op verzorgend en buishoudelijk gebied met de Groningen Activiteiten Restrictie Schaal (GARS): een bandleiding (Measuring functional status with regard to personal and domestic care by the Groningen Activity Restriction Scale: a manual). Groningen: Noordelijk Centrum voor Gezondheidsvraagstukken, Rijksuniversiteit Groningen 1993.

32. Van Campen C, Kerkstra A. Kwaliteit van leven van somatische verpleeghrispatiënten. Een begripsverbeldering en overzicht van meetinstrumenten (Quality of life of somatic patients in nursing homes. A detailed definition and an overview of measurement instruments). Utrecht: The Netherlands Institute 
for Health Services Research (NIVEL) 1995.

33. Walker A (Ed.). Growing older. Understanding quality of life in old age. Berkshire: Open University Press 2005.

34. Nunnally JCJ. Psychometric Theory, 2e edn. New York: McGraw-Hill 1978.

35. Van Eijk LM, Miedema I. Ouderen op de wachtlijst nader bekeken. Een onderzoek onder ouderen op de wachtlijst voor een verzorgingshuis in Oost-Groningen (A closer look at elderly people on a waiting list for residential care in East Groningen). Groningen: Provinciaal Ontwikkelingsinstituut Zorg en Welzijn (POZW) 2001.

36. Kingston P, Bernard M, Biggs S, Nettleton H. Assessing the health impact of age-specific housing. Health and Social Care in the Community 2001, 9:228-234.

37. HHM. Landelijke rapportage resultaten wachtlijstinventarisatie sector Verpleging en Verzorging; peildatum 1 november 2002 (National report on the existence of waiting lists in Care and Nursing; reference date 1 November 2002). Enschede: Bureau Hoeksma, Homans \& Menting organisatieadviseurs 2003. 


\section{SHELTERED HOUSING COMPARED TO INDEPENDENT HOUSING IN THE COMMUNITY}

PMA van Bilsen, JPH Hamers, W Groot, C Spreeuwenberg 


\section{ABSTRACT}

With elderly people desiring to live independently as long as possible, traditional homes for the elderly are increasingly being transformed into sheltered accommodations. In order to assess the importance of housing for frail elderly people, elderly people at risk for institutionalization were studied in two living conditions: sheltered accommodation and living independently in the community.

A total of 317 elderly people at risk for institutionalization (91 men and 240 women, mean age $=83.3(\mathrm{SD}=6.0)$ ) were interviewed using a structured questionnaire with questions regarding home care and social service use, quality of life, subjective well-being, life satisfaction, autonomy, functional status, feelings of insecurity and loneliness.

$56.5 \%$ of the respondents were living in sheltered accommodation $(n=179)$ and $43.5 \%(\mathrm{n}=138)$ were living in regular houses. Although both groups were similar in demographic details and functional status, those in sheltered accommodation had a higher perceived autonomy, sense of security and quality of life. No differences were found with regard to subjective well-being or feelings of loneliness. Elderly people in regular houses needed more hours of housekeeping assistance. Those in sheltered accommodation participated more frequently in services like social activities and social restaurants, but made less use of day care facilities.

Affordable, decent and suitable non-institutional housing with service provision play a vital role in the lives of elderly people. Compared to independent living in the community, sheltered accommodations provide added value. Sheltered housing should therefore be an integral part of long-term care policy. 


\section{INTRODUCTION}

Now that older people in Western countries prefer to live independently as long as possible, policies and services are increasingly focusing on living in the community rather than on institutions as the primary axis of care [1-8]. This has resulted in the expansion of all types of sheltered accommodation providing an independent living environment alongside opportunities for care up to the level of full residential care [9-11]. There is no internationally accepted and unambiguous definition of sheltered housing, and labels like retirement housing, board and care home, old age home or assisted living are often used interchangeably. In general, sheltered housing for older persons represents a housing arrangement in between independent living in the community and a residential institution $[9,12,13]$. Sheltered accommodations are purpose-built for elderly people who prefer to live independently but want the reassurance of knowing that assistance and care are available and close by if there is an emergency or if functional impairments are deteriorating. Some wide-ranging characteristics can be distinguished [9, 13-17]. Sheltered housing normally involves a concentration of apartments adapted to the needs of elderly people (e.g., no stairs, 24-hour home care alert, specially adapted and easy access bathrooms and kitchens, handrails, widened doors in hallways) with more or less 'sheltered' features like communal facilities (laundry, garden) or rooms for social, cultural and creative activities. Above all, these accommodations are linked to social and care services.

Reasons for elderly people to move into sheltered housing are varied $[9,12-$ $14,18]$ and include feelings of insecurity, loneliness and the costs of home repairs, heating and garden upkeep. People also move in order to forestall problems or relieve the concerns of relatives who are worried about an older person living alone. But the most commonly reported reason is the poor health of a person or their spouse, followed by possibly related problems of their old home no longer being suitable (e.g., because of stairs) and because they want to have an alert system available just in case.

Sheltered housing claims to offer a secure and social living environment in which frail elderly people with functional impairments can remain independent and receive care when needed. Kingston et al (2001) even concluded that sheltered accommodations combine the best elements of residential care and neighbourhood communities, based on the finding that health (both physical and mental) of people living in a retirement community compared favourable with that of a regular community sample [18]. Walker et al (1998) found that the prevalence of depression was lower in sheltered housing than in the rest of the community [14]. This result becomes even more relevant if we consider that these sheltered living elderly people are more functionally and cognitive disabled, and limited than those living independently $[12,14]$. Also Van der Scheer et al (2003) found more chronic illness among elderly people living in sheltered accommodation compared to those living independently [12]. That people in 
sheltered accommodations suffer from serious impairments is also evident from the finding that quite a few elderly persons living in sheltered housing in the Netherlands are also on waiting lists for residential care and therefore at risk for institutionalization [19].

Altogether, sheltered housing seem to offer adequate housing for disabled elderly people, even when they are at risk for institutionalization. However, less is known about the perception of sheltered living elderly in terms of quality of life, subjective well-being, feelings of insecurity, loneliness and autonomy. Do they perceive equal e.g. autonomy compared to independently living elderly? Do they feel less lonely compared to independent living elderly? It is evident that these aspects are of significant importance for successful ageing [20, 21]. Therefore, the aim of this study was to examine the importance of housing (sheltered housing versus independently in the community) for elderly at risk for institutionalization in terms of functional status, services use as well as quality of life measures. People at risk for institutionalization are defined as people who are - based on a uniform nationwide assessment device - eligible for admission into homes for the elderly [22-24]. As a result they are registered on a waiting list for residential care or are entitled to care on demand, 24 hours a day.

The research questions in this study were:

- Do elderly people living in sheltered accommodation differ in terms of personal characteristics (e.g., age, gender, living alone), functional status and service use from those living independently in the community, considering the fact that both groups are at risk for institutionalization?

- What are the subjective levels of well-being, life satisfaction, loneliness, quality of life, autonomy and security of elderly persons living in sheltered housing compared to elderly persons living independently in the community, both of whom are at risk for institutionalization?

\section{METHODS}

\section{Design}

To answer the research questions, a cross-sectional study was conducted. Over a period of three months, we interviewed elderly people in two regions in the Netherlands (the province of Zeeland and the Westelijke Mijnstreek region in the province of Limburg).

\section{Subjects}

All elderly people (older than 65 years) who were at risk for institutionalization but still living independently in the community or in sheltered housing, were recruited by the caregivers in both regions $(n=1050)$. These elderly had made an official request for admission to residential care or care on demand (24 hours a day) at so called needs assessment agencies [23]. These agencies positively evaluated the legitimacy of the client's request based on an objectively needs assessment procedure. 


\section{Procedure and ethical considerations}

Written information about the study was sent to elderly persons selected by the managing directors of all care giving institutions involved. Information was given about the aim of the study, research method (interview), the procedure, anonymity with regard to data analysis, telephone number in case the elderly people required more information. Special attention has been paid to the fact that participation was voluntary.

A few days after the written information had been sent, they were contacted by telephone to obtain consent for participation. If they agreed, a date was set for an interview. Reasons for refusal were systematically recorded.

No approval of an established medical ethical board was needed because the respondents were not subjected to procedures or were not required to follow rules of behaviour (Central Committee on Research involving Human subjects, known by the Dutch initials CCMO) [25].

\section{Data collection}

Data were collected by means of interviews using a structured questionnaire. In total four interviewers were trained to conduct the interviews. During a two hour training session, information was given about the goal of the study and the questionnaire.

\section{Measures}

In order to answer the first research question, questions were asked about personal characteristics (age, gender, living situation), functional status and service use.

Functional status was measured by the Groningen Activity Restriction Scale [26]. This measure was explicitly chosen based on satisfying psychometric properties [26, 27]. Respondents were asked to indicate to what extent they were still able to engage in activities of daily living related to personal care (ADL) (11 activities) and activities related to independent living, including preparing meals, shopping for groceries and performing light or heavy housework (IADL) (7 activities). The activities are listed in Table 1 . The respondents had to answer on a 3-point ordinal scale to what extent they were able to carry out activities of daily living, ranging from performing them completely independently (score 1) to performing them only with help from others (score 3) (see Table 2).

The use of formal health care and social services was assessed by asking the respondents whether they visited day care centres or were receiving assistance for housekeeping, personal or nursing care. They were also asked how many hours a week of housekeeping, personal or nursing care they were receiving. These answers were categorized into classes (1:0-1.9 hours a week; 2:2-3.9 hours a week; 3:4-6.9 up to 20-24.9 hours a week). The use of social services was assessed by asking the respondents if they made use of services like 24-hour home care alert, counselling (individual and group therapy), information 
provision (personal advisor), social activities (social restaurant, telephone circle and buddy project) and additional services like home library service and administrative assistance.

Table $1 \mathrm{ADL}$ and IADL activities assessed by the Groningen Activity Restriction Scale (functional status)

\begin{tabular}{l|l}
\hline ADL activities & IADL activities \\
\hline - getting dressed & - preparing breakfast or lunch \\
- getting in and out of bed & - preparing dinner \\
- getting out of a chair & - performing light household activities \\
- washing your hands and face & (e.g., dusting, doing the dishes) \\
- washing and drying your whole body & - performing strenuous household activities \\
- visiting the toilet & (e.g., mopping, window cleaning) \\
- eating and drinking & - doing and ironing the laundry \\
- moving around in the house & - making the bed \\
- going up and down stairs & - doing your grocery shopping \\
- moving outside the house & \\
- taking care of your feet & \\
&
\end{tabular}

In order to answer the second research question, the respondents were asked questions about subjective well-being (vitality, mental health), life satisfaction, loneliness, quality of life, autonomy and insecurity. Except from the measures 'autonomy' and 'insecurity', we used measures which have been proved to have satisfying psychometric properties, have been tested and are found sufficient in other studies [28-32]

Subjective well-being was measured with two subscales of the RAND-36 Health Survey (RAND-36): 'mental health' (5 items) and 'vitality' (4 items) [28] The respondents had to answer on a 6-point ordinal scale to what extent they felt nervous, depressed, lively, tired, energetic or exhausted. The answering categories varied from 'constantly' (score 1) to 'never' (score 6) (see Table 2). These scores were transformed to a 100-point scale, with higher scores indicating greater perceived subjective well-being.

The respondents' opinion about life satisfaction was measured with the Satisfaction With Life Scale (SWLS) (5 items), which has proved to be a valid and reliable measure [30]. The respondents had to answer on a 7-point scale to what extent they agreed with propositions about life satisfaction like 'My life is ideal in most respects' or 'On the whole, I'm satisfied with my life'. Answering options varied from 'I strongly disagree' (score 1), to 'I strongly agree' (score 7) (see Table 2). Higher scores indicated a more positive perception of life satisfaction.

Loneliness was measured with the Rasch-type loneliness scale (11 items) [31, 32] Respondents had to answer on a 5-point ordinal scale to what extent they felt they lacked a special friend or company in general, or experienced feelings of loneliness and emptiness. The answering categories were: 'Yes!', 'Yes', 'More or less', 'No' and 'No!'. The answers were then dichotomized resulting in a scale 
from 0 to 11 . Higher scores implied that the respondents experienced more feelings of loneliness (see Table 2).

Overall quality of life was assessed with one question on a Visual Analogue Scale (VAS). The respondents had to indicate their quality of life on a $100 \mathrm{~mm}$ Visual Analogue Scale (VAS) (with '0' representing very low quality of life and '100' representing very high quality of life). However, during the data collection we have found that the phrasing of this question and the accompanying request to put a mark on the VAS caused problems. In order to prevent too many missing values, we introduced an alternative assessment method for those elderly who were not able to put a mark on the VAS. These respondents were asked to give a grade between 0 and 100 .

Autonomy and feelings of insecurity are very important aspects of quality of life for elderly people, especially when they become more disabled and fragile $[21,33,34]$. No valid and reliable instruments to measure these two aspects were available [33]. Therefore, 10 self-developed items were added (6 items about autonomy and 4 items about insecurity). The items were phrased on the basis of results of earlier research about elderly people's basic and care needs [34]. Consequently, the items appear on the surface to have face validity. Respondents had to answer on a 5-point ordinal scale to what extent they felt dependent on others, were receiving care at the moments when they wanted it and felt secure in their own home and social environment. The answering categories were: 'Yes!', 'Yes', 'More or less', 'No' and 'No!'. A higher score meant that the respondents felt they were more independent from others and more secure (see Table 2).

All measurement instruments proved to be internally consistent (with a Cronbach's $\alpha$ range based on the data of 0.70 to 0.89 ), except for feelings of insecurity (Cronbach's $\alpha=0.34$ ) [35] (for a summary of the measures, see Table 2). Since feelings of insecurity are often mentioned as an important reason to move into sheltered accommodation, these items were nevertheless described and analyzed separately, with the answers of sheltered living respondents being compared with the answers of those living independently.

\section{Analyses}

Descriptive statistics were computed for the personal and health-related characteristics of the respondents (frequencies, mean, deviation, sum scores). Differences between respondents living in a sheltered accommodation and those who lived independently in regular housing were investigated using chi-square test for variables at a dichotomous level and One-way Anova for variables at an interval and ratio level. The normality of the variables was checked by frequencies and distribution tables. The data were analyzed using SPSS, version 13.0 
Table 2 Summary of some of the variables measured

\begin{tabular}{|c|c|c|c|c|c|}
\hline \multirow[t]{2}{*}{ Domains } & \multirow{2}{*}{$\begin{array}{l}\text { Number } \\
\text { of items }\end{array}$} & \multirow[t]{2}{*}{ Range } & \multirow{2}{*}{$\begin{array}{c}\text { Cronbach's } \\
\alpha\end{array}$} & \multicolumn{2}{|c|}{ Meaning of scores } \\
\hline & & & & Low & High \\
\hline $\begin{array}{l}\text { Functional } \\
\text { status } \\
\text { - ADL } \\
\text { - IADL }\end{array}$ & $\begin{array}{r}18 \\
11 \\
7\end{array}$ & $\begin{array}{r}18-54 \\
11-33 \\
7-21\end{array}$ & $\begin{array}{l}0.89 \\
0.86 \\
0.78\end{array}$ & $\begin{array}{l}\text { Seriously limited in } \\
\text { performing all types } \\
\text { of (I)ADL activities } \\
\text { independently }\end{array}$ & $\begin{array}{l}\text { Performing all } \\
\text { types of daily } \\
\text { (I)ADL activities } \\
\text { without help from } \\
\text { others }\end{array}$ \\
\hline \multicolumn{6}{|l|}{ Well-being } \\
\hline - vitality & 4 & $0-100$ & 0.78 & $\begin{array}{l}\text { Feeling tired and } \\
\text { worn out all of the } \\
\text { time }\end{array}$ & $\begin{array}{l}\text { Feeling full of zest } \\
\text { and energy all of } \\
\text { the time }\end{array}$ \\
\hline - mental health & 5 & $0-100$ & 0.76 & $\begin{array}{l}\text { Feeling nervous and } \\
\text { depressed all of the } \\
\text { time }\end{array}$ & $\begin{array}{l}\text { Feeling peaceful, } \\
\text { happy and calm all } \\
\text { of the time }\end{array}$ \\
\hline - life satisfaction & 5 & $5-25$ & 0.75 & $\begin{array}{l}\text { Low perceived life } \\
\text { satisfaction }\end{array}$ & $\begin{array}{l}\text { High perceived life } \\
\text { satisfaction }\end{array}$ \\
\hline Loneliness & 11 & $0-11$ & 0.85 & $\begin{array}{l}\text { Having no feelings } \\
\text { of loneliness }\end{array}$ & $\begin{array}{l}\text { Having serious } \\
\text { feelings of } \\
\text { loneliness and } \\
\text { emptiness }\end{array}$ \\
\hline Autonomy & 6 & $6-30$ & 0.70 & $\begin{array}{l}\text { Perceiving } \\
\text { dependence on } \\
\text { others }\end{array}$ & $\begin{array}{l}\text { Not perceiving } \\
\text { dependence on } \\
\text { others }\end{array}$ \\
\hline Insecurity & 4 & $4-20$ & 0.34 & $\begin{array}{l}\text { Feelings of } \\
\text { insecurity }\end{array}$ & $\begin{array}{l}\text { Greater perceived } \\
\text { security }\end{array}$ \\
\hline
\end{tabular}

\section{RESULTS}

Sample

A considerable proportion $(n=343,32.7 \%)$ of the elderly persons originally selected $(n=1050)$ were excluded for several reasons. For 198 persons, no valid address or phone number were available due to registration problems or administrative failure $(n=198)$. Twenty persons had already moved to a home for the elderly. With regard to 125 persons, relatives or informal caregivers informed us that the persons selected were unable to participate because they were deceased or severely communicatively impaired (see Table 3). Of the remaining elderly people ( $\mathrm{n}=707), 61$ could not be reached by telephone, even though we tried over a considerable period of time. Another 161 persons showed no interest. Eighty-two persons claimed to be too sick, confused or disabled (e.g., 
because of hearing or vision problems) to participate in the study. Eventually, 334 interviews were conducted. Based on the 707 persons we reached by phone, the response was $47 \%$. Seventeen respondents were excluded afterwards because they had moved into homes for the elderly in the meantime. Unfortunately it is unknown whether these respondents lived sheltered or independently in the community before moving to a home for the elderly.

Table 3 Total response and overview of reasons for non-response $(n=1050)$

\begin{tabular}{|l|r|}
\hline Response flow & Total \\
\hline Number of people selected & 1050 \\
\hline Excluded & -314 \\
\hline Prospective participants & 707 \\
\hline Number of people who could not been reached over a lengthy period of time & -61 \\
\hline Numbers of people who did not want to participate: & -161 \\
\hline - lack of interest & -82 \\
\hline - being too sick, confused or disabled (people answered the telephone) & -69 \\
\hline - other reasons & 334 \\
\hline $\begin{array}{l}\text { Total number of interviews } \\
17 \text { elderly people had moved into homes for the elderly in the meantime and were } \\
\text { excluded }\end{array}$ & -17 \\
\hline Total number of respondents & 317 \\
\hline
\end{tabular}

\section{Demography}

Demographic details of the respondents $(n=317)$ are given in Table 4 . There were no statistically significant differences between the respondents living in sheltered housing and those living independently in the community in terms of age, gender or living situation (living alone or with others).

Table 4 Personal characteristics and functional status $(n=317)$

\begin{tabular}{|c|c|c|c|}
\hline Characteristics of the respondents & Independent & Sheltered & p-value ${ }^{3}$ \\
\hline $\mathrm{N}$ & $138(43.4 \%)$ & $179(56.5 \%)$ & \\
\hline Age $(S D)^{1}$ & $83.6(5.5)$ & $83.1(6.3)$ & 0.49 \\
\hline Gender (female) ${ }^{2}$ & $97(70.3 \%)$ & $129(72.1 \%)$ & 0.73 \\
\hline Living alone ${ }^{2}$ & $107(77.5 \%)$ & $143(79.9 \%)$ & 0.61 \\
\hline $\begin{array}{r}\text { Functional Status }^{1} \\
- \text { ADL } \\
- \text { IADL }\end{array}$ & $\begin{array}{l}32.9(7.6) \\
17.9(4.7) \\
15.1(3.7)\end{array}$ & $\begin{array}{l}31.9(7.2) \\
17.1(4.3) \\
14.7(3.5)\end{array}$ & $\begin{array}{l}0.19 \\
0.14 \\
0.41\end{array}$ \\
\hline
\end{tabular}

${ }^{1}$ ANOVA (one-way), ${ }^{2}$ Chi square, ${ }^{3} \mathrm{p} \leq 0.05$ 


\section{Functional status}

There was no statistically significant difference in functional status between the two groups (see Table 4). This means that the respondents living in sheltered housing had the same level of functional disability and needed similar assistance from others as those living independently.

\section{Care and social service use}

The respondents living in the community were receiving more hours of housekeeping assistance per week $(\mathrm{p}<0.01)$ compared to sheltered living respondents. As can be seen in Table 5, 42.7\% of the independent living respondents were receiving 4 to 6.9 hours per week housekeeping assistance, while only $18.4 \%$ of the sheltered living respondents were receiving equal hours per week. Further, respondents in sheltered housing not only received nursing care more frequently $(\mathrm{p}<0.01)$, they also received more hours per week nursing care compared to independent living respondents $(\mathrm{p}=0.02)$. Respondents living in the community visited day care facilities more frequently $(\mathrm{p}<0.01)$.

Almost all respondents in sheltered housing had a 24-hour personal alert system $(83.7 \%)$, compared to $63.2 \%$ of those living independently $(p<0.01)$. Respondents in sheltered housing made more use of social and cultural activities $(\mathrm{p}<0.01)$ and social restaurants $(\mathrm{p}=0.01)$ than those living in ordinary housing in the community. 
Table 5 Care and social service use $(n=317)$

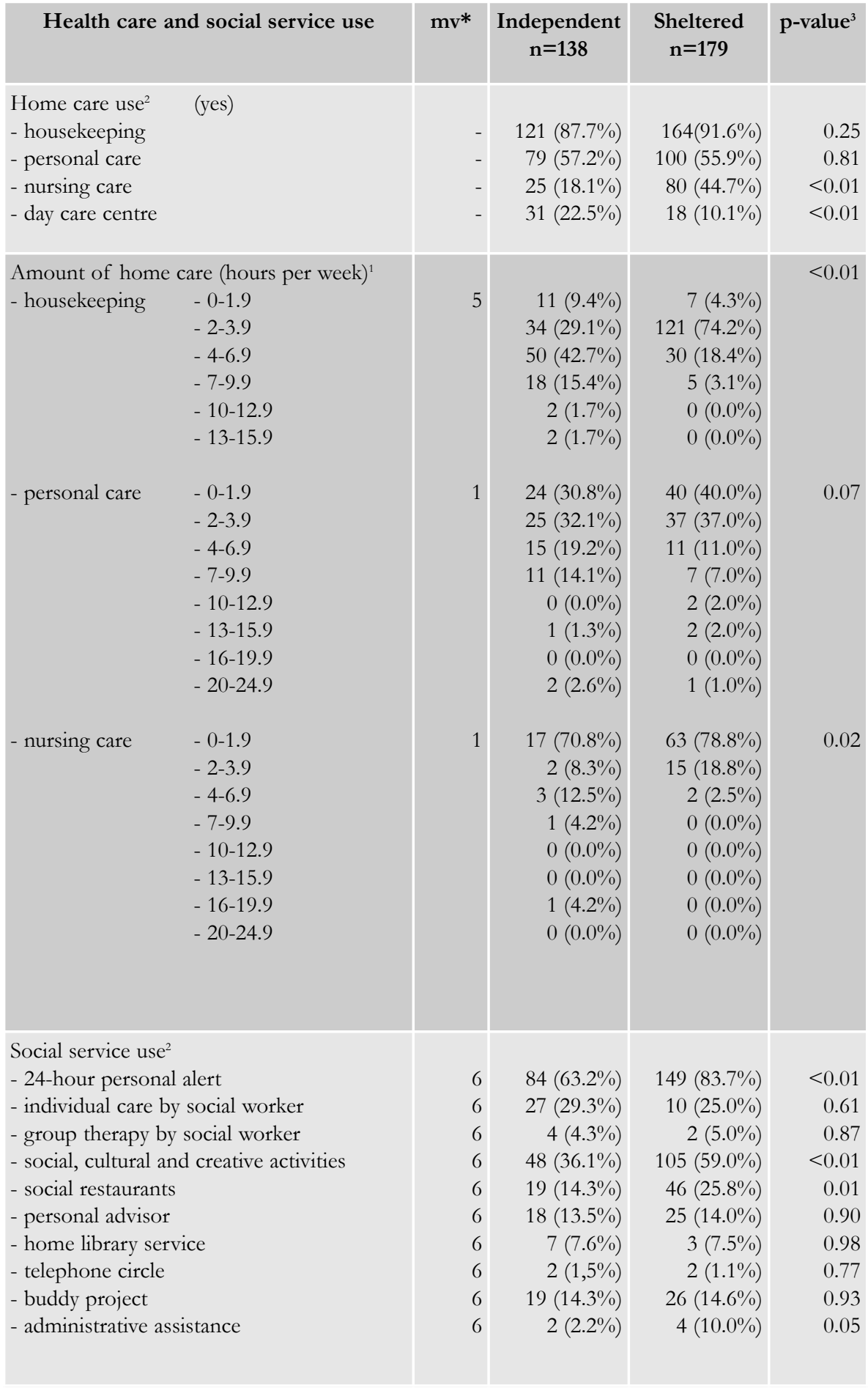

*Missing values, ${ }^{1}$ Kendall's tau-b, ${ }^{2}$ Chi square, ${ }^{3} \mathrm{p} \leq 0.05$ 


\section{Subjective well-being and loneliness}

No differences between the two groups were found with regard to subjective well-being (see Table 6). Respondents in both groups had equal scores for vitality (in terms of being tired, worn out or full of zest and energy) and mental health (in terms of being nervous, depressed or peaceful, happy and calm). Selfrated opinion about life satisfaction and feelings of loneliness were also equal for both groups: respondents in sheltered housing and those living independently in the community were equally satisfied about their lives and equally affected by feelings of loneliness (Table 6.)

Table 6 Subjective well-being, loneliness, autonomy, quality of life and feelings of security; respondents in sheltered housing compared to those living independently in the community $(\mathrm{n}=317)$

\begin{tabular}{|c|c|c|c|c|}
\hline Characteristics of the respondents & mv* & $\begin{array}{c}\text { Independent } \\
n=138\end{array}$ & $\begin{array}{c}\text { Sheltered } \\
\mathrm{n}=179\end{array}$ & $\mathrm{p}$-value ${ }^{2}$ \\
\hline $\begin{array}{l}\text { Subjective wellbeing } \\
\text { - vitality }(0-100) \\
\text { - mental health }(0-100) \\
\text { - life satisfaction (5-35) }\end{array}$ & $\begin{array}{l}3 \\
4 \\
5\end{array}$ & $\begin{array}{r}54.7(19.3) \\
67.1(17.1) \\
26.0(5.6)\end{array}$ & $\begin{array}{r}58.1(16.9) \\
69.4(16.1) \\
26.4(5.4)\end{array}$ & $\begin{array}{l}0.10 \\
0.22 \\
0.52\end{array}$ \\
\hline Feelings of loneliness $(0-11)^{1}$ & - & $3.5(3.0)$ & $3.1(3.0)$ & 0.26 \\
\hline Perceived autonomy $(6-30)^{1}$ & - & $23.4(3.7)$ & $24.7(3.1)$ & $<0.01$ \\
\hline $\begin{array}{l}\text { Quality of life }(0-100) 1 \\
\text { - quality of life (VAS) ( } \mathrm{n}=172,54.3 \%) \\
\text { - quality of life (report mark) ( } \mathrm{n}=116,36.6 \%)\end{array}$ & 29 & $\begin{array}{l}59.0(18.5) \\
55.5(18.1) \\
66.9(17.1)\end{array}$ & $\begin{array}{l}65.1(15.9) \\
62.0(16.9) \\
70.2(13.6)\end{array}$ & $\begin{array}{r}<0.01 \\
0.02 \\
0.26\end{array}$ \\
\hline $\begin{array}{l}\text { Feelings of insecurity1 } \\
\text { - I do not feel secure when going outdoors } \\
\text { on my own in the daytime. } \\
\text { - As a result of my limitations, I feel very } \\
\text { vulnerable on my own. } \\
\text { - When I am home alone, I am afraid. } \\
\text { - I stay inside after dark. }\end{array}$ & - & $\begin{array}{l}4.3(1.1) \\
1.7(1.1)\end{array}$ & $\begin{array}{l}3.7(1.2) \\
3.7(1.1) \\
4.7(0.7) \\
1.4(1.0)\end{array}$ & $\begin{array}{r}0.37 \\
<0.01 \\
<0.01 \\
0.02\end{array}$ \\
\hline
\end{tabular}

*Missing values, ${ }^{1}$ ANOVA one-way, ${ }^{2} \mathrm{p} \leq 0.05$

\section{Quality of life, autonomy and feelings of insecurity}

Respondents living in sheltered accommodations had greater perceived autonomy than those living independently in the community $(\mathrm{p}<0.01)$ (Table 6$)$. Respondents in sheltered housing also evaluated their quality of life more positively (65.1) than those living independently in the community (59.0) $(\mathrm{p}<0.01)$ (Table 6$)$. However, a distinction has been made between elderly people who indicated their quality of life on a $100 \mathrm{~mm}$ VAS, and those who gave a report mark. Although the findings were comparable, only the results within the group elderly who put a mark on the VAS were statistic significantly $(\mathrm{p}=0.02)$.

Four questions were asked about feelings of insecurity (Table 6). The results show that the respondents were generally not afraid of being alone at home, and 
still felt relatively secure when outdoors on their own. Most respondents confirmed that they tended to stay inside after dark. Group comparisons show that respondents in sheltered housing felt less vulnerable on their own and were less afraid when they were home alone than those living independently in the community $(\mathrm{p}<0.01$ and $\mathrm{p}<0.01$, respectively). Respondents living independently were slightly less outspoken on the item 'I stay inside after dark' $(p=0.02)$.

\section{DISCUSSION}

The most prominent finding of this study is that two comparable groups of frail elderly people in two different housing conditions differed in perceived quality of life, autonomy and feelings of insecurity; respondents living in sheltered housing evaluated their quality of life more favourably and experienced greater autonomy and fewer feelings of insecurity than respondents living independently in the community. The two groups did not differ in personal characteristics (e.g., age, gender, living alone, physical impairment), functional status, vitality, mental health, life satisfaction or feelings of loneliness.

Some interesting differences were found with regard to care and services use. Respondents in sheltered housing were more likely to receive nursing care and participated more in social activities. By contrast, respondents living independently in the community received more hours of housekeeping assistance and made more use of day care centres.

This study has some limitations. In the first place, since we used a cross-sectional design, no definite conclusions regarding causal relationships can be drawn. Secondly, the number of elderly people on the original mailing list who could not be reached $(n=343)$ was rather high, as was the number of elderly persons who refused to participate in the study $(n=373)$. In view of the reasons for not being available and non-response, the possibility of selection bias cannot be ignored. It is likely that this study covered mostly elderly people who were in relatively good health. However, it must be remembered that all people selected were entitled to receive residential care and 24-hour services (i.e. were at risk for institutionalization) based on their functional impairments. Besides, the main goal of this study was to examine the differences between elderly people living in a sheltered accommodation and those living in regular houses in the community. These two groups proved to be comparable in terms of demographic details or functional impairments. Thirdly, the measures we have used to assess autonomy and feelings of insecurity were self-developed. The scale 'autonomy' proved to be internally consistent (reliability), and is expected to have face validity, considering the fact that the items were based on a literature review and in-depth interviews with elderly people [34]. Furthermore, the scale discriminated as expected between the groups independent living elderly and sheltered living elderly which could be seen as an indication of convergent 
validity. The scale 'insecurity' was not internally consistent, so no further research to establish validity has been conducted. Therefore, the results with regard to autonomy and insecurity must be interpreted with caution. Future research should address ways of assessing both concepts in a valid and reliable way. Especially, because staying independent is a driving force for many elderly people and feelings of insecurity has proved to be a major issue for the general well-being of elderly people and one of the motivating factors that has consistently emerged as a reason to move to sheltered housing [18]. Fourthly, although the VAS is the essence of simplicity, in this sample in the present study $40 \%$ of the respondents had perceived difficulties with using the VAS. This was mainly caused by visual problems or lack of understanding. This phenomena has already been described [36]. In order to prevent too many missing values, we introduced an alternative assessment method for those who were not able to put a mark on the VAS (report mark). Although, the findings are in general comparable - sheltered living elderly reported a higher quality of life compared to independent living elderly - the VAS seems to be more sufficient in detecting this difference. In future, a more adequate measure for quality of life should be used considering this fragile and old research population. Streiner \& Norman (2003) recommend the use of vertical 'thermometer' in stead of a horizontal VAS [36]. This instrument proved to be easier for older people to complete. Finally, a comment needs to be made with regard to the definition of sheltered housing. The definition we used is very broad, as we made no distinction between types of sheltered housing or service characteristics of the housing types. However, all respondents in sheltered accommodation were living independently in blocks of apartments purpose-built for elderly people with impairments (including home modifications, personal alert system, supervision and communal rooms). Above all, these adequate accommodations were linked to social and care services.

Sheltered accommodation offers a non-institutional housing condition that attracts elderly people by its perceived combination of security, availability of care services and emphasis on independence, privacy and personal dignity. The results presented above allow the conclusion that the communal and sheltered features of these accommodations increase elderly people's perceived autonomy compared to those living independently in the community. In addition, respondents living in sheltered housing experienced greater quality of life and security than those living in the community. In this sense, sheltered housing combines the favourable attributes of residential care (sheltered accommodation, care facilities, personal alert system) and those of living in the community (privacy, autonomy). We thus support the conclusion by Kingston et al (2001) that sheltered living accommodations combine the best elements of residential care and neighbourhood communities [18].

The question has been raised whether sheltered housing can prevent elderly 
people from having been admitted into homes for the elderly, which is a relevant political issue in view of the waiting lists for residential care in the Netherlands. Although waiting lists for homes for the elderly have decreased by $23 \%$ over the 2000-2003 period, the problem has not yet been fully solved [37]. Interestingly, there is little international attention for waiting lists in the care sector. This does not mean, however, that they do not exist [38, 39]. Young \& Turnock (2001) showed that disabled older people are being confronted with multiple waiting lists in community care for each of the range of services or equipment they require (e.g., home adaptations, day care centres, residential places, equipment for disabled living (kitchen and bathing aids, wheelchairs, pressure relieving mattresses). Feder et al (2000) concluded that people who need long-term care do not get the care they need or prefer. It is unclear, however, whether the advent of sheltered housing is leading to a decrease in waiting lists for residential care or community care. The added value of sheltered living should be the subject of further research [39].

The importance of affordable, decent and suitable non-institutional housing linked to services plays a crucial role in the lives of elderly people with disabilities, because of the amount of time they spend in their homes and their desire to 'age in place'. Sheltered housing should therefore be an integral part of long-term care policy. In practice, ageing in place for many elderly people still means living in substandard housing in the community with inadequate supportive features or moving to non-preferred institutional settings [40]. This should be prevented in a society faced with increasing numbers of frail elderly people with disabilities. New strategies and approaches should be developed to increase housing options, including home modifications, linkage between housing and services and various forms of supportive housing.

\section{CONCLUSION}

Affordable, decent and suitable non-institutional housing with service provision play a vital role in the lives of elderly people. Compared to independent living in the community, sheltered accommodations provide added value; elderly people living in sheltered accommodations had a higher perceived autonomy, sense of security and quality of life. Sheltered housing should therefore be an integral part of long-term care policy.

\section{REFERENCES}

1. Borgenicht K, Carty E, Feigenbaum LZ. Community Resources for Frail Older Patients. The Western Journal of Medicine 1997, 167:291-294.

2. Gibler KM, Moschis GP, Lee E. Planning to move to retirement housing. Financial Services Review 1998, 7:291-300.

3. Rosenberg M, Everitt J. Planning for aging populations: inside or outside the walls. Progress in Planning 2001, 56:199-168.

4. Van Bilsen PMA, Hamers JPH, Groot W, Spreeuwenberg C. Een andere kijk op de 
Chapter 5

wachtlijstproblematiek. De behoefte van ouderen aan verzorgingshuiszorg (An other perspective on waiting lists. The need of elderly people for residential care). Maastricht: Universitaire Pers Maastricht 2003.

5. Rauner MS, Vissers JMH. OR applied to health services: Planning for the future with scarce resources. European Journal of Operational Research 2003, 150:1-2.

6. Cox CB. Community Care for an Aging Society. Issues, Policies and Services. New York: Springer Publishing Company, Inc. 2005.

7. Hellström Y, Hallberg IR. Determinants and characteristics of help provision for elderly people living at home and in relation to quality of life. Scandinavian Journal of Caring Sciences 2004, 18:387-395.

8. Ministry of Health, Welfare and Sport. Ouderenbeleid in het perspectief van de vergrijzing (Elderly policy in the context of a greying population). The Hague: Ministry of Health Welfare and Sport (VWS) 2005.

9. Nocon A, Pleace N. Sheltered Housing and Community Care. Social Policy \& Administration 1999, 33:164-180.

10. Mandemaker T, Christ L. De volledige extramuralisering van het verzorgingshuis (The transformation of homes for the elderly into extramural health care). Utrecht: Netherlands Institute for Care and Welfare (NIZW) 2005.

11. Nouws $H$. Het transformatieproces van verzorgingshuizen: vier recente cases (The transformation of homes for the elderly: four recent examples). Utrecht: Aedes-Arcares kenniscentrum Wonen-Zorg 2004.

12. Van der Scheer E, Boersma F, Deeg D. Gezondheidstoestand en zorggebruik van bewoners van services-ouderenwoningen. Een vergelijking met zelfstandig wonenden. (The health status and health care use of elderly people living in sheltered residences. A comparison with elderly people living independently). Tijdschrift voor Gerontologie en Geriatrie 2003, 34:162-167.

13. Field EM, Walker MH, Orrell MW. Social networks and health of older people living in sheltered housing. Aging \& Mental Health 2002, 6:372-386.

14. Walker M, Orrell M, Manela M, Livingston G, Katona C. Do health and use of services differ in residents of sheltered accommodation? A pilot study. International Journal of Geriatric Psychiatry 1998, 3:617-624.

15. www.HousingCare.org.

16. Zimmerman S, Sloane PD, Eckert JK. Emerging Issues in Residential Care/Assisted Living. In: Zimmerman S, Sloane PD, Eckert JK, editors. Assisted Living. Needs, Practices and Policies in Residential Care for the Elderly. Baltimore \& London: The John Hopkins University Press 2001.

17. www.senior-community.net/assisted-living.htm.

18. Kingston P, Bernard M, Biggs S, Nettleton H. Assessing the health impact of age-specific housing. Health and Social Care in the Community 2001, 9:228-234.

19. Van Bilsen PMA, Hamers JPH, Don AAM, Groot W, Spreeuwenberg C. Extra welizinn voor ouderen in de thuissituatie: een alternatief voor verzorgingshuiszorg? (Additional social services for elderly people at home: an alternative for residential care?). Maastricht: Universitaire Pers Maastricht 2007.

20. Marmot M. The status syndrome. How social standing affects our health and longevity. New York: Henry Holt and Company 2004.

21. Walker A (Ed). Growing older. Understanding quality of life in old age. Berkshire: Open University Press 2005. 
22. National Council for Public Health. Indicatiestelling en zorg op maat: advies van de Nationale Raad voor de Volksgezondheid en het College voor Ziekenhuisvoorzieningen (Needs assessments and customised care: recommendations by the National Council for Public Health and the Council for Hospital Facilities). Zoetermeer: National Council for Public Health 1994.

23. Ministry of Health, Welfare and Sports. Zorgindicatiebesluit; Besluit van 2 oktober 1997, houdende regels met betrekking tot werkterrein, de samenstelling en werkwijze van indicatieorganen (Care Needs Assessment Decree; White Paper of October, 2, 1997, regulating the activities, formation and mode of operation of Regional Needs Assessment Agencies). Staatsblad van het Koningrijke der Nederlanden 1997, Sdu 447.

24. Maarse H, Van der Made J. Cost containment and the right to health care. European Journal of Public Health 1998, 8:119-126.

25. Centrale Commissie Mensgebonden Onderzoek (Committee on Research involving Human Subjects). Retrieved 2007 from www.ccmo.nl.

26. Kempen GIJM, Doeglas DM, Suurmeijer TPBM. Het meten van problemen met zelfredzaambeid op verzorgend en buishoudelijk gebied met de Groningen Activiteiten Restrictie Schaal (GARS): een handleiding (Measuring functional status with regard to personal and domestic care by the Groningen Activity Restriction Scale: a manual). Groningen: Noordelijk Centrum voor Gezondheidsvraagstukken, Rijksuniversiteit Groningen 1993.

27. Kempen GIJM, Miedema I, Ormel J, Molenaar W. The assessment of disability with the Groningen Activity Restriction Scale. Conceptual framework and psychometric properties. Social Science \& Medicine. 1996, 43:1601-1610.

28. Van der Zee KI, Sanderman R. Het meten van de algemene gezondheidstoestand met de RAND-36: een bandleiding (Measuring health with the RAND-36: a manual). Groningen: Noordelijk Centrum voor Gezondheidsvraagstukken (NCG) 1993.

29. Moorer P, Suurmeijer PBM, Foets M, Molenaar IW. Psychometric properties of the RAND36 among three chronic diseases (multiple sclerosis, rheumatic diseases and COPD) in the Netherlands. Quality of Life Research 2001, 10:637-645.

30. Diener E, Emmons RA, Larsen RJ, Griffin S. The satisfaction with life scale. Journal of Personality Assessment 1985, 49:71-75.

31. De Jong-Gierveld J, Kamphuis F. The development of a Rasch-type loneliness scale. Applied Psychological Measurement 1985, 9:289-299.

32. De Jong-Gierveld J, Van Tilburg T. Manual of the Loneliness Scale. Retrieved February 9, 2004, from http://home.scw.vu.nl/ tilburg/manual_loneliness_scale_1999.html

33. Van Campen C, Kerkstra A. Kwaliteit van leven van somatische verpleeghuispatiënten. Een begripsverbeldering en overzicht van meetinstrumenten (Quality of life of somatic patients in nursing homes. A detailed definition and an overview of measurement instruments). Utrecht: Netherlands Institute for Health Services Research (NIVEL) 1995.

34. Van Bilsen PMA, Hamers JPH, Groot W, Spreeuwenberg C. Welke zorg vragen ouderen? Een inventarisatie (What care do elderly people ask for? An overview). Maastricht: Universitaire Pers Maastricht 2002.

35. Nunnally JCJ. Psychometric Theory. 2e ed. New York McGraw-Hill 1978.

36. Streiner DL, Norman GR. Health measurement scales. A practical guide to their development and use. New York: Oxford University Press 2003. 
Chapter 5

37. Van Gameren E. Regionale verschillen in de wachtlijsten verpleging en verzorging. Een empirisch onderyoek naar verklarende factoren. (Regional differences in waiting lists for nursing and care facilities. An empirical study of determinants). The Hague: Social and Cultural Planning Office (SCP) 2005.

38. Young J, Turnock S. Community care waiting lists and older people. BMJ 2001, 322:254.

39. Feder J, Komisar HL, Niefeld M. Long-term care in the United States: An overview. Health Affairs 2000, 19:40-56.

40. Pynoos J, Nishita CM. Housing. In: Evashwick CJ (Ed.). The continuum of long-term care. Long Beach: Thomson Delmar Learning 2005. 
Sheltered housing compared to independent housing 


\section{6}

THE USE OF COMMUNITY-BASED SOCIAL SERVICES BY ELDERLY PEOPLE AT RISK FOR INSTITUTIONALIZATION: AN EVALUATION

PMA van Bilsen, JPH Hamers, W Groot \& C Spreeuwenberg 


\section{ABSTRACT}

The purpose of this study was to explore the use of community-based social services by elderly people at risk of institutionalization, but who prefer to remain at home.

A study with a longitudinal design with measurements at two points in time was conducted. Data were collected using structured interviews, including questions regarding service use, functional status, quality of life, subjective wellbeing, autonomy and feelings of loneliness.

134 elderly people (mean age $=82$ years) participated at baseline and at 12 months follow-up. At baseline, 81 respondents indicated that they made use of at least one social service $(60.4 \%)$. After one year this number of respondents did increase, but not significantly $(64.2 \%, \mathrm{p}=0.53)$. Only two services (sociocultural activities and restaurant facility) out of five services were used frequently at 12-months follow-up. The use of the other services was limited. Although functional status, perceived well-being and quality of life did not change, elderly people reported more autonomy and fewer feelings of loneliness after one year. These positive changes cannot be related to an increased use of services.

Despite the offer of extra social services, the use of these services by elderly people at risk of institutionalization did not increase over a one year period. Overall, the use of social services remained moderate. This raises questions about the perceived need for these services, the possible barriers, the population 'elderly people at risk of institutionalization' and the ability of these social services to contribute to de-institutionalization. 


\section{INTRODUCTION}

Many elderly people in western countries indicate a desire to live independently and maintain control over their lives as long as possible, preferable in their own homes. For the majority of the elderly people an institutionalized setting is a choice of last resort, often a result of a health-related crisis. Consequently, elderly people require care at home and additional support when needed [1-6].

Generally speaking, policies and services are focusing more and more on the community rather than on institutions as the primary axis of long-term care for elderly people [7-10]. Community-based long-term care is defined as the combination of preventive, therapeutic, and supportive services options, provided by health care professionals and other formal and informal caregivers in the community, to meet the individualized needs of the elderly [5]. Above all, community-based long-term care and services are intended to support people in their activities of daily living, so they are able to function independently at home, or delay admittance to institutionalized settings [3, 4, 10-17].

Social services (e.g., senior citizen centres, distance-based health care, mealson-wheels of transport facilities) as part of community-based long-term care have become common. Little is known, however, about the actual use of these services and added value. Studies focusing on the use of community-based care mostly do not attempt to distinguish between the effect of the individual services (e.g., home care, social services, adult day health care) and, therefore, they offer no evidence on the relative need or effectiveness of these services individually [11, 17, 18]. Furthermore, research into community-based care including social services, has mainly focused on barriers or facilitators that influence older adults' utilization of community-based services in general. These influencing factors include knowledge, awareness, availability (waiting lists), transportation and gaps in community services, all of which can interfere with older adults' use of services needed [3, 4, 18-24]. One special subject of interest concerns the lack of linkage between health care and social services in providing effective home-based support $[25,26]$. In this respect, the need for adequate care management (called service coordination) has proven to be effective [27].

Following national policy in the Netherlands to develop and improve community-based long-term care for elderly people [28, 29], a coordinated package of social services in addition to existing regular home care and day care has been developed. These social services can be divided into counselling activities (individual and group counselling), provision of information (personal adviser), companion services (restaurant facility, telephone circle and buddy project), socio-cultural activities (e.g., sports, excursions, social activities), and services like home library service and administrative support. These social services are focused on responding to the wish of elderly at risk of institutionalization to remain living independently in the community by improving their ability to cope for themselves (functional status, mobility, autonomy, loneliness) and diminish their risk for admission Furthermore, it is 
expected that elderly people feel better (subjective well-being, life satisfaction) in their own familiar environment, which then contributes to their quality of life. 'At risk of institutionalization' means that these elderly - based on a uniform nationwide assessment device - are eligible for admission into homes for the elderly [30]. As a result they are registered on a waiting list for homes for the elderly or are entitled to care on demand, 24 hours a day. In order to encourage elderly people to make use of the social services in the region, the costs of their participation were compensated by an extra government-sponsored financial contribution [29].

The primary aim of this study is to evaluate the use of five social services which have been set up: socio-cultural activities, restaurant facilities, personal adviser, telephone circle and buddy project. In order to examine the service use over time, measurements took place at two points in time: at baseline and one year later after introduction of the community-based social services. Secondly, in order to understand the use of these social services, the relationship between potential determinants (e.g., functional status, subjective well-being and mobility) and social service use were studied. More specifically, the following questions were posed:

- To what extent are community-based home care and social services being used by elderly at risk of institutionalization at baseline and one year later?

- Is there a relationship between social service use and (in)formal care use, functional status, subjective well-being, life satisfaction, loneliness, autonomy, mobility and quality of life of elderly at risk of institutionalization?

\section{DESIGN AND METHODS}

\section{Design}

A study with longitudinal design was conducted. Measurements at two points in time (12-months follow-up) took place by interviewing elderly people at home.

\section{Subjects}

The managing directors of the homes for the elderly in two regions in the Netherlands (the Province of Zeeland and the province of Limburg), selected elderly people (older than 65 years) who were at risk of institutionalization but still living independently in the community $(n=707)$. These elderly had made an official application for admission into a home for the elderly or care on demand (24 hours a day) at assessment agencies. These agencies evaluate the legitimacy of the client's request based on an objectively needs assessment procedure [30, 31].

\section{Procedure and ethical considerations}

All elderly 'at risk' in both regions were personally informed by the care-giving institutions in both regions about the social services available, how to make use 
of these services and the extra government-sponsored financial contribution [29].

Shortly after the social services have become available, a letter was sent to the selected respondents to inform them about the study. A few days after this letter had been sent, they were contacted by telephone to ask whether they would like to participate. If they agreed, a date was set for an interview (baseline measurement). Reasons for refusal were systematically recorded. The respondents who were interviewed at baseline were contacted a second time one year after the first interview took place. Again a letter was sent, followed by a telephone call a few days later (12-months follow-up).

No approval of an established medical ethical board was needed because the respondents were not subjected to procedures or were not required to follow rules of behaviour (Central Committee on Research Involving Human Subjects (known by the Dutch initials CCMO) [32].

\section{Measures}

Data were collected by means of interviews using a structured questionnaire. In order to answer the first research question, questions were asked about the use of social services. The respondents were asked to indicate whether they use the following services: socio-cultural activities, restaurant facility, personal advisor, telephone circle or buddy project. All five were passed in review during the interview. The respondents had to answer with a simple 'yes' or 'no'.

While social services are mostly used in addition to regular home care, the use of (in)formal health care was also assessed by asking the respondents whether they visited day care facilities, or were receiving professional assistance for housekeeping, personal or nursing care. The respondents could answer these questions with a plain 'yes' or 'no'. Informal care was measured by one question: Are you receiving assistance from informal caregivers on a regular basis?

In order to answer the second question, questions were asked about functional status, accessibility problems in and outside their house, subjective well-being (vitality, mental health, life satisfaction), feelings of loneliness, quality of life and autonomy. Except from the self-developed measures 'autonomy' and the mobility-scale, we used measures which have proved to have satisfying psychometric properties [34-39) .

Functional status was measured using the Groningen Activity Restriction Scale $(39,40)$. Respondents were asked to indicate to what extent they were still able to engage in activities of daily living related to personal care (ADL) (eleven activities) and activities related to independent living, including preparing meals, shopping for groceries and performing light or heavy housework (IADL) (seven activities). The meaning of the scores are described in Table 1.

The respondents' perceived accessibility problems in and outside their house and nearby area (in short 'mobility') were assessed by five questions, so as, to 
assess their mobility and functional impairment in getting around. These questions were derived from the assessment protocol of the assessment agency. The respondents had to answer on a three-point ordinal scale to what extent they had problems moving around inside and outside their house, using the bathroom, kitchen or toilet and the accessibility of public facilities like grocery shops, bus stops or banks. Higher scores mean that the respondents experienced more problems with their housing and nearby residential area (see Table 1).

Subjective well-being consists of an affective, emotional component and a self-rated satisfaction with life component. The affective component was measured with two subscales of the RAND-36 Health Survey (RAND-36): 'mental health' (five items) and 'vitality' (four items) $(34,35)$. The respondents had to answer on a six-point ordinal scale to what extent they felt nervous, depressed, lively, tired, energetic or exhausted. These scores were transformed into a 100-point scale, with higher scores indicating greater perceived subjective well-being (see Table 1).

The respondents' opinion about life satisfaction was measured with the Satisfaction With Life Scale (SWLS) (five items) (36). The respondents had to answer on a seven-point scale to what extent they agreed with propositions about life satisfaction such as 'My life is ideal in most respects' or 'On the whole, I'm satisfied with my life.' Higher scores indicated a more positive perception of life satisfaction (see Table 1).

Loneliness was measured with the Rasch-type loneliness scale (eleven items) $(37,38)$. Respondents had to answer on a five-point ordinal scale to what extent they felt they lacked a special friend or company in general, or experienced feelings of loneliness and emptiness. The answers then were recoded, resulting in a scale from 0 to 11 . Higher scores implied that the respondents experienced more feelings of loneliness (see Table 1).

One item was added about the respondents' perceived quality of life. They were asked to indicate their quality of life on a $100-\mathrm{mm}$ Visual Analogue Scale (VAS) (with '0' representing very low quality of life and '100' representing very high quality of life). We found that the phrasing of this question and the accompanying request to put a mark on the VAS caused problems. In order to avoid too many missing values, we introduced an alternative assessment method for those elderly people who were not able to put a mark on the VAS. These respondents were asked to give a grade between 0 and 100 (see Table 1).

Unfortunately, no valid and reliable instrument to measure autonomy was available (41). Therefore, six self-developed items were added. The items were phrased on the basis of results of earlier research about elderly people's basic and care needs $(42,43)$. Respondents had to answer on a five-point ordinal scale to what extent they felt dependent on others or were receiving care at the moments when they wanted it. A higher score meant that the respondents felt they were more independent of others (see Table 1).

In addition, some supplementary personal characteristics were asked. These 
included region (Zeeland or Limburg), age, gender, living alone or with somebody else and housing. It should be noted that the variable 'housing' was recoded at baseline into regular housing in the community and purpose-built sheltered accommodation for elderly people. At the follow-up measurement, one housing category was added (intramural setting).

The measurement instruments proved to be internally consistent at baseline (with a Cronbach's $\alpha$ range based on the data of 0.67 to 0.89) (44) (see Table 1). Table 1 consists of a summary of the variables measured, as well as a short description of the meaning of the scores.

Table 1 Summary statistics of the variables measured at baseline

\begin{tabular}{|c|c|c|c|c|c|c|}
\hline \multirow[t]{2}{*}{ Domains } & \multirow{2}{*}{$\begin{array}{l}\text { No. } \\
\text { items }\end{array}$} & \multirow[t]{2}{*}{ Range } & \multirow{2}{*}{$\begin{array}{c}\text { Cronbach's } \\
\alpha\end{array}$} & \multirow{2}{*}{$\begin{array}{c}\text { Mean } \\
\text { score (sd) }\end{array}$} & \multicolumn{2}{|c|}{ Meaning of scores } \\
\hline & & & & & Low & High \\
\hline $\begin{array}{l}\text { Functional } \\
\text { status }\end{array}$ & 18 & $18-54$ & 0.89 & $32.1(7.4)$ & $\begin{array}{l}\text { Seriously limited } \\
\text { in performing all } \\
\text { types of (I)ADL } \\
\text { activities } \\
\text { independently }\end{array}$ & $\begin{array}{l}\text { Performing all } \\
\text { types of daily } \\
\text { (I)ADL activities } \\
\text { without help from } \\
\text { others }\end{array}$ \\
\hline $\begin{array}{l}\text { Accessibility } \\
\text { of house } \\
\text { and near } \\
\text { area }\end{array}$ & 5 & $0-10$ & 0.67 & $1.7(1.9)$ & $\begin{array}{l}\text { No problems } \\
\text { with the } \\
\text { accessibility of } \\
\text { their home and } \\
\text { nearby area }\end{array}$ & $\begin{array}{l}\text { Great perceived } \\
\text { problems with the } \\
\text { accessibility of } \\
\text { their home and } \\
\text { nearby area }\end{array}$ \\
\hline Vitality & 4 & $0-100$ & 0.76 & $57.8(17.3)$ & $\begin{array}{l}\text { Feeling tired and } \\
\text { worn out all of } \\
\text { the time }\end{array}$ & $\begin{array}{l}\text { Feeling full of zest } \\
\text { and energy all of } \\
\text { the time }\end{array}$ \\
\hline $\begin{array}{l}\text { Mental } \\
\text { health }\end{array}$ & 5 & $0-100$ & 0.77 & $68.9(16.1)$ & $\begin{array}{l}\text { Feeling nervous } \\
\text { and depressed all } \\
\text { of the time }\end{array}$ & $\begin{array}{l}\text { Feeling peaceful, } \\
\text { happy and calm all } \\
\text { of the time }\end{array}$ \\
\hline $\begin{array}{l}\text { Life } \\
\text { satisfaction }\end{array}$ & 5 & $5-35$ & 0.74 & $26.5(5.3)$ & $\begin{array}{l}\text { Low perceived } \\
\text { life satisfaction }\end{array}$ & $\begin{array}{l}\text { High perceived life } \\
\text { satisfaction }\end{array}$ \\
\hline Loneliness & 11 & $0-11$ & 0.79 & $3.2(2.9)$ & $\begin{array}{l}\text { Having no } \\
\text { feelings of } \\
\text { loneliness }\end{array}$ & $\begin{array}{l}\text { Having serious } \\
\text { feelings of } \\
\text { loneliness and } \\
\text { emptiness }\end{array}$ \\
\hline $\begin{array}{l}\text { Quality of } \\
\text { life }\end{array}$ & 1 & $0-100$ & - & $64.3(16.7)$ & $\begin{array}{l}\text { Very low quality } \\
\text { of life }\end{array}$ & $\begin{array}{l}\text { Very high quality } \\
\text { of life }\end{array}$ \\
\hline Autonomy & 6 & $6-30$ & 0.68 & $24.3(3.3)$ & $\begin{array}{l}\text { Perceiving } \\
\text { dependence on } \\
\text { others }\end{array}$ & $\begin{array}{l}\text { Not perceiving } \\
\text { dependence on } \\
\text { others }\end{array}$ \\
\hline
\end{tabular}




\section{Statistical methods}

Statistical evaluation of the study aims began with descriptive (frequencies, mean, deviation, sum scores) and dropout analyses of outcome and control variables, followed by a comparison between baseline and follow-up measurement. Use of community-based social services was measured as participating in at least one social service. A multivariate logistic model was developed to explore the association between personal and health-related characteristics on social service use at twelve-month follow-up. Only those characteristics that had a statistically significant bivariate association $(\mathrm{p} \leq 0.05)$ with social service use were included in the model. The odds ratios (OR) and corresponding 95\% confidence intervals (CI) derived from the model are effect estimates simultaneously adjusted for other factors in the model.

\section{RESULTS}

\section{Sample}

A total of 707 elderly persons at risk of institutionalization were selected by caregivers to participate in this study. It should be mentioned that 61 elderly people were never reached because there was no answer after prolonged attempts. The most common reason for non-response was lack of interest $(n=163)$. Another 82 persons claimed to be too sick, confused or disabled to participate. An additional 28 elderly said they had no time, and 3 elderly had objections on principle to scientific research. Thirty-six persons refused to give a reason for non-response. Eventually, 334 interviews were conducted (response rate of $47 \%$ ). Figure 1 presents a chart of the recruitment strategy. No background information is available about the selected elderly whom we were not able to contact and the non-responders.

With regard to the research questions, we excluded another 17 respondents because they had moved into homes for the elderly at follow-up measurement, and another 25 respondents, who specifically pointed out that they preferred admission to a home for the elderly and no longer want to live independently. The sample at baseline thus consisted of 292 elderly people.

Eventually, 134 respondents (46\%) were interviewed twice, at baseline and 12 months later. The most often-mentioned reasons for dropping out were lack of interest and illness. Consequently, the comparison between the baseline and follow-up measurement was conducted on 134 respondents who participated at two moments in time. This sample included 95 females $(71 \%)$ and 39 males (29\%). At the follow-up measurement, the average age was 82.4 years (SD 6.0, range 67-97), 105 respondents (78\%) were living on their own, while 29 respondents were living together with someone else $(22 \%)$. Eighty-one respondents $(60 \%)$ were living in street-level apartments fully adapted to elderly people (sheltered housing), while 53 respondents (40\%), lived in non-street-level apartments or in a regular house with a two floors upstairs (without a lift to reach 
Figure 1 Sample and recruitment strategy

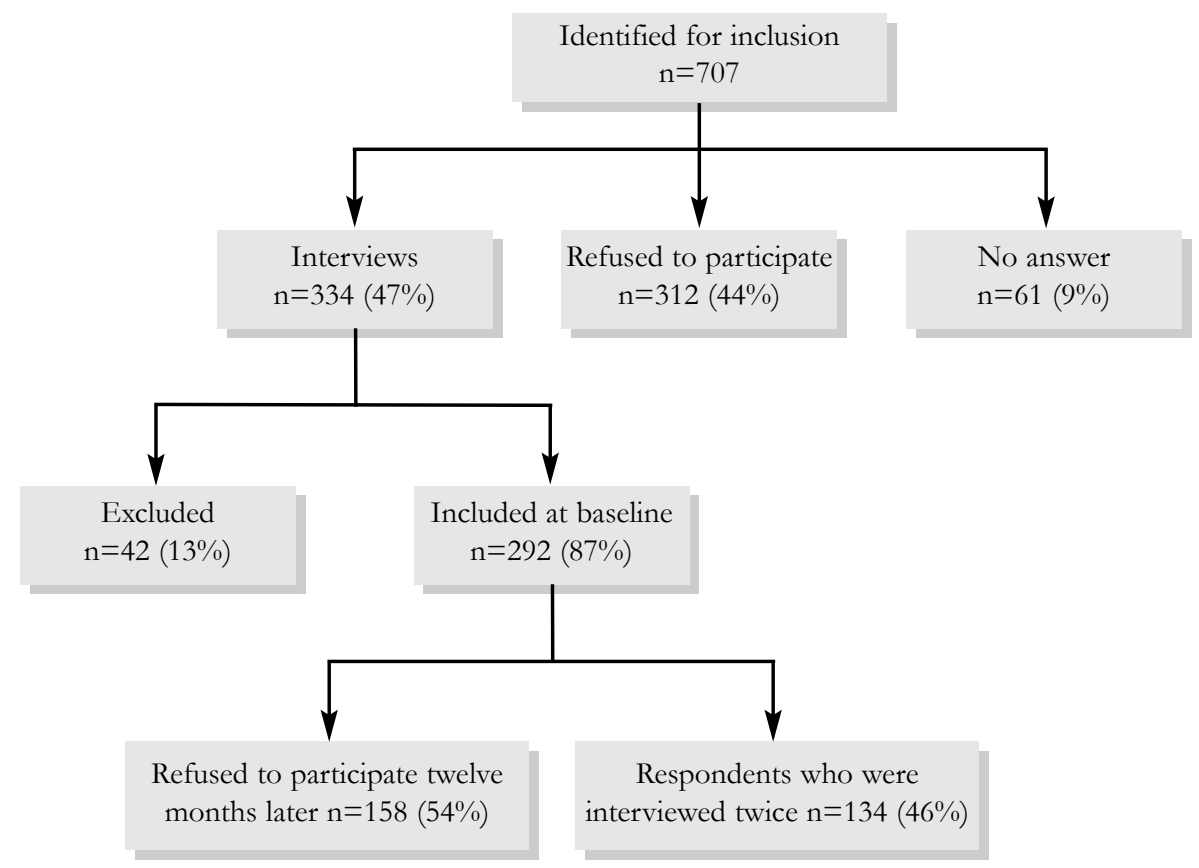

them). Twelve months later, eight respondents who lived in a regular house at baseline moved to another setting; one respondent moved to a sheltered accommodation and seven respondents moved to a home for the elderly. In addition, more respondents were living alone at follow-up measurement $(\mathrm{n}=107)$.

\section{Dropout analysis}

A comparison of the baseline characteristics of elderly people who participated at two measurements in time, and those who dropped out, showed that these two groups were comparable in most characteristics (region, age, gender, housing, living condition, subjective well-being, functional status, feelings of loneliness, perceived autonomy, and accessibility of house and nearby area) (see Table 2). Also the use of home care and social service use was similar. As can be derived from Table 2, the only differences were found with regard to informal care and quality of life. Respondents who dropped out during the study received informal care more often and perceived less quality of life $^{1}$. The dropouts tended to be older and more functionally impaired (functional status, accessibility of house and nearby area, personal care) than the respondents who were interviewed twice.

${ }^{1}$ A distinction has been made between elderly people who indicated their quality of life on a 100 $\mathrm{mm}$ VAS, and those who gave a grade. Although the findings are comparable, only the results within the group elderly who gave a grade were statistic significantly $(\mathrm{p}=0.003)$. 
Table 2 Baseline comparison of elderly people who were interviewed twice (at baseline and twelve months later) and dropouts on personal and health-related characteristics, and social service use

\begin{tabular}{|c|c|c|c|}
\hline Characteristics & $\begin{array}{c}\text { Both interviews } \\
n=134\end{array}$ & $\begin{array}{l}\text { Dropouts } \\
n=158\end{array}$ & p-value ${ }^{c}$ \\
\hline Region (Province of Zeeland) ${ }^{\mathrm{b}}$ & $93(69.4 \%)$ & $89(56.3 \%)$ & 0.022 \\
\hline $\operatorname{Age}^{\mathrm{a}}$ & $82.4(\operatorname{sd} 6.0)$ & $84.2($ sd 5.7) & 0.010 \\
\hline Gender (female) ${ }^{b}$ & $95(70.9 \%)$ & $117(74.1 \%)$ & 0.547 \\
\hline Housing (sheltered) ${ }^{b}$ & $81(60.4 \%)$ & $89(56.3 \%)$ & 0.477 \\
\hline Living condition (alone) ${ }^{\mathrm{b}}$ & $105(78.4 \%)$ & $126(79.7 \%)$ & 0.771 \\
\hline Informal care ${ }^{\mathrm{b}}$ yes) & $78(58.6 \%)$ & $118(75.2 \%)$ & 0.003 \\
\hline $\begin{array}{l}\text { Formal home care use }{ }^{\mathrm{b}} \\
\text { - household assistance (yes) } \\
\text { - personal care (yes) } \\
\text { - nursing (yes) } \\
\text { - day care (yes) }\end{array}$ & $\begin{array}{r}122(91.0 \%) \\
64(47.8 \%) \\
40(29.9 \%) \\
16(11.9 \%)\end{array}$ & $\begin{array}{r}140(88.6 \%) \\
98(62.0 \%) \\
62(39.5 \%) \\
28(17.7 \%)\end{array}$ & $\begin{array}{l}0.464 \\
0.015 \\
0.086 \\
0.169\end{array}$ \\
\hline $\begin{array}{l}\text { Subjective well-being } \\
\text { - vitality }(0-100) \\
\text { - mental health }(0-100) \\
\text { - opinion about life satisfaction (5-35) }\end{array}$ & $\begin{array}{r}59.5(16.2) \\
70.1(15.8) \\
26.7(5.2)\end{array}$ & $\begin{array}{r}56.3(18.2) \\
67.7(16.3) \\
26.2(5.4)\end{array}$ & $\begin{array}{l}0.112 \\
0.206 \\
0.488\end{array}$ \\
\hline Functional status $(18-54)^{\mathrm{a}}$ & $31.1(7.1)$ & $33.0(7.6)$ & 0.027 \\
\hline Feelings of loneliness $(0-11)^{\mathrm{a}}$ & $3.0(2.9)$ & $3.3(3.0)$ & 0.264 \\
\hline Perceived autonomy $(6-30)^{a}$ & $24.7(3.5)$ & $23.9(3.1)$ & 0.046 \\
\hline $\begin{array}{l}\text { Quality of life }(0-100)^{a} \\
\text { - quality of life (VAS) } \\
\text { - quality of life (grade) }\end{array}$ & $\begin{array}{l}67.7(15.1) \\
63.3(16.0) \\
73.7(11.5)\end{array}$ & $\begin{array}{l}61.4(17.4) \\
58.3(17.5) \\
65.6(16.4)\end{array}$ & $\begin{array}{l}0.002 \\
0.065 \\
0.003\end{array}$ \\
\hline Accessibility of house and nearby area $(0-10)^{a}$ & $1.4(1.9)$ & $1.9(2.0)$ & 0.042 \\
\hline Use of at least one social service & $83(62.4 \%)$ & $112(72.7 \%)$ & 0.062 \\
\hline
\end{tabular}

${ }^{a} \mathrm{~T}$-Test, ${ }^{\mathrm{b}} \mathrm{Chi}$ square, $\mathrm{p}$-value fixed at $\leq 0.003$ (correction for multiple testing, Bonferroni procedure)

\section{Home care and social service use}

At baseline, 81 of the 134 respondents indicated that they made use of at least one social service $(60.4 \%)$ in contrast to $39.6 \%$ of the respondents who did not use any social service at all. Twelve months later, the amount of respondents using at least one service did not increase significantly $(64.2 \%, \mathrm{p}=0.533)$. As 
shown in Table 3, the average number of social services used at baseline did not increase significantly in time $(\mathrm{p}=0.510)$. Additionally, there was no statistically significant change in home care use and informal care.

The use of formal and informal care did not change statistically significantly during the 12-months follow-up (see Table 3).

Table 3 Comparison between baseline and 12-months follow-up in terms of (in) formal home care and the number of social services used $(n=134)$

\begin{tabular}{|c|c|c|c|}
\hline Social service use $^{\mathrm{b}}$ & Baseline & 12-months follow-up & p-value ${ }^{c}$ \\
\hline No social service use & $53(39.6 \%)$ & $48(35.8 \%)$ & 0.533 \\
\hline The use of at least one service & $81(60.4 \%)$ & $86(64.2 \%)$ & \\
\hline \multicolumn{4}{|l|}{ Number of social services used } \\
\hline No social service use & $53(39.6 \%)$ & $48(35.8 \%)$ & \\
\hline One service & $47(35.1 \%)$ & $48(35.8 \%)$ & \\
\hline Two services & $26(19.4 \%)$ & $30(22.4 \%)$ & \\
\hline Three services & $7(5.2 \%)$ & $8(6.0 \%)$ & \\
\hline Four services & $1(0.7 \%)$ & - & \\
\hline Mean number of services ${ }^{\mathrm{a}}$ & $0.9(\operatorname{sd} 0.9)$ & $1.0(\operatorname{sd} 0.9)$ & 0.510 \\
\hline \multicolumn{4}{|l|}{ Home care useb } \\
\hline Household assistance (yes) & $122(91,0 \%)$ & $127(94.8 \%)$ & 0.125 \\
\hline Personal care (yes) & $64(47.8 \%)$ & $72(53.7 \%)$ & 0.115 \\
\hline Nursing (yes) & $40(29.9)$ & $48(35.8 \%)$ & 0.134 \\
\hline Day care (yes) & $16(11.9 \%)$ & $17(12.7 \%)$ & 1.000 \\
\hline Informal care (yes) & $77(58.3 \%)$ & $76(57.6 \%)$ & 1.000 \\
\hline
\end{tabular}

a Paired sample test, ${ }^{\mathrm{b}} \mathrm{McNemar},{ }^{\mathrm{c}} \mathrm{p} \leq 0.05$

At both moments in time, the most frequently used services were socio-cultural activities and restaurant facilities (Table 4). The use of the various social services separately did not change significantly, except for the service of 'personal adviser'. The amount of respondents who consulted a personal adviser decreased significantly during a 12-months period. 
Table 4 Comparison between baseline and 12-months follow-up in terms of social service use $(\mathrm{n}=134)^{\mathrm{a}}$

\begin{tabular}{|l|r|r|r|}
\multicolumn{1}{|c|}{ Social services } & \multicolumn{1}{c|}{ Baseline } & 12-months follow-up & \multicolumn{1}{c|}{ p-value } \\
\hline Social, cultural and creative activities & $67(50.0 \%)$ & $73(54.5 \%)$ & 0.430 \\
\hline Restaurant facility & $30(22.4 \%)$ & $35(26.1 \%)$ & 0.405 \\
\hline Personal adviser & $13(9.7 \%)$ & $4(3.0 \%)$ & 0.049 \\
\hline Telephone circle & $1(0.7 \%)$ & $1(0.7 \%)$ & 1.000 \\
\hline Buddy project & $13(9.7 \%)$ & $19(14.2 \%)$ & 0.307 \\
\hline
\end{tabular}

${ }^{\mathrm{a}} \mathrm{McNemar},{ }^{\mathrm{b}} \mathrm{p} \leq 0.05$

Personal and health-related characteristics

At post-test, the respondents felt significantly less lonely and more independent of others compared to one year before perceived autonomy. Contrary, the respondents were less vital and perceived more problems with the accessibility of their house and nearby environment at 12-months follow-up (Table 5).

Table 5 Comparison between baseline and 12-months follow-up in terms of personal and healthrelated characteristics $(\mathrm{n}=134)^{2}$

\begin{tabular}{|l|r|r|r|}
\hline \multicolumn{1}{|c|}{ Characteristics } & Baseline & $\begin{array}{l}\text { 12-months } \\
\text { follow-up }\end{array}$ & p-value $^{\text {b }}$ \\
\hline $\begin{array}{l}\text { Subjective Well-being } \\
\text { - vitality (0-100) } \\
\text { - mental health (0-100) } \\
\text { - opinion about life satisfaction (5-35) }\end{array}$ & $59.5(16.2)$ & $56.2(18.5)$ & 0.050 \\
\hline Functional Status (18-54) & $70.1(15.8)$ & $71.8(15.6)$ & 0.191 \\
\hline Feelings of loneliness (0-11) & $26.7(5.3)$ & $26.2(6.0)$ & 0.288 \\
\hline Perceived autonomy (6-30) & $31.1(7.1)$ & $31.5(7.3)$ & 0.230 \\
\hline Quality of life (0-100) & $3.0(2.9)$ & $2.3(2.4)$ & 0.005 \\
\hline Problems with housing \& social environment (0-10) & $24.7(3.5)$ & $25.9(3.5)$ & 0.002 \\
\hline
\end{tabular}

aPaired sample T-Test, ${ }^{\mathrm{b}} \mathrm{p} \leq 0.05$

\section{Factors related to social service use at post-test}

Because of the limited number of respondents $(n=134)$ and the numerous possible predictors (see Table 2), bivariate analyses of outcome and control variables were conducted first. Respondents who made use of at least one social service were compared with those who said they did not use any social service at all. The results showed that respondents who received nursing care, were less likely to use social services $(p=0.007)$. Furthermore, users of social services were more likely to live in sheltered accommodations $(p=0.003)$ and in the province 
of Zeeland $(\mathrm{p}=0.014)$.

To quantify the effect of these variables (nursing care, housing and region) on social service use, a logistic regression analysis by social service use was conducted. The results showed that living in sheltered accommodations (OR 2.4, $\mathrm{CI}=1.1-4.9, \mathrm{p}=0.020$ ) was the only statistically significant determinant of social service use.

\section{CONCLUSION AND DISCUSSION}

The most prominent finding of this study was that the use of community-based social services, especially set up to enable elderly people to remain independently at home, was moderate and did not increase during a one-year period. With the exception of social activities (e.g., sports, games, excursions) and the restaurant facility, limited use was made of the social services (buddy project, telephone circle and personal adviser).

Although functional status, mental health, life satisfaction and quality of life did not change, elderly people reported more autonomy and fewer feelings of loneliness after one year. These positive changes cannot be related to an increased use of services. On the contrary, at follow-up measurement the respondents were less vital and perceived more problems with the accessibility of their house and nearby environment. Logistic regression analysis has shown that living in sheltered accommodations was the only statistically significant determinant of social service use.

A major limitation of this study concerns the dropout. Comparison on baseline characteristics between respondents who participated twice and respondents who dropped out during the study showed that the dropouts received informal care more often, and had a lower perceived quality of life. Moreover, the dropouts tended to be older and more functionally impaired. These results imply that the study tested comparatively younger respondents, who perceived a better quality of life. Nevertheless, it is not expected that the dropout biased the results, since both groups were similar with regard to their social service use at baseline. Furthermore, this study used a longitudinal design with measurements at two points in time (12-months follow-up). As a result, final conclusions regarding causal relationships could not be drawn. In addition, the scales 'autonomy' and 'accessibility of house and nearby area' haven proven to be internally consistent (reliability) and are expected to have face validity. However, more research on psychometric properties of both scales is needed. At last, it would seem advisable to use a more easily manageable measure for quality of life. Although the VAS is the essence of simplicity, in this sample $40 \%$ of the respondents perceived difficulties with using the VAS mainly caused by visual problems or lack of understanding. Although the findings of quality of life measured by the VAS or assessed by a grade are in general comparable (see Table 2), it seems advisable to have only one method of measuring. 
The predominant finding of this study was that the use of community-based social services is very moderate and, for some services, even poor. This raises questions about the perceived need of elderly 'at risk' for these services, the nature of the services offered, the accessibility of those services, the population 'elderly people at risk of institutionalization', and the ability of these social services to contribute to de-institutionalization. These aspects will be explained below.

Community-based long-term care and services aim to support people in their activities of daily living so they are able to function independently at home. Consequently, community-based care fits into a demand-driven oriented health care system, in which health care supply is guided by elderly people's wants and their basic need to age in place. However, limited use is made of the social services offered, with the exception of socio-cultural activities and restaurant facility. This raises questions about the desirability of these specific services. Based on the results of this study, it is recommended that providers and health care insurers be encouraged to examine the need of elderly people for social services and that prospective users are invited to explain precisely what it is they want in terms of social care. Our previous research showed that elderly people when asked, immediately brought up their needs and wants for services and support that would enable them to continue to live in their homes as long as possible (43). Based on these findings, the model 'The relations between health care needs, resources and demands' has been developed in order to create demand-driven services to meet clients' needs and preferences $(2,42,45)$. According to this model, the resources of persons (e.g., mobility, informal care, housing) should be paramount in the development of services. Resources are defined as circumstances or means which that enable and support elderly people to fulfil their basic needs (e.g., need for autonomy, safety, social life, leisure). Consequently, a need for care or support is a result of insufficient resources being available. This model could be a helpful tool for policymakers and caregivers in reconsidering the perceived need and nature of the services offered.

Alternatively, it is also possible that elderly people at risk of institutionalization do have a perceived need for these specific services, but are unable to use them. Therefore, possible barriers (e.g., accessibility, transport, costs, lack of knowledge) to the use of these services should be studied. The results of the logistic regression analysis showed that living in sheltered accommodations was the main determinant for social service use. This factor is obviously related to the accessibility and approachability of social services, on the one hand, and the ability of elderly persons to use them, on the other. The fact that social activities are usually organized at communal locations, linked to sheltered living facilities or homes for the elderly, increases the accessibility of these activities for elderly people living in such facilities. This explains why respondents living in sheltered accommodations or institutional settings were 
more likely to use social services than those living in regular houses. Existing knowledge about barriers and facilitators that influence older adults' utilization of social services $(3,4,18-22)$ could be useful in detecting possible barriers to using the social services in this study.

These community-based social services were specially set up for elderly people at risk of institutionalization, who were old and impaired and were already receiving home care for household chores, personal care and nursing. Even within one year, they became less vital and perceived more problems with the accessibility of their house and nearby environment. So, it could be asked whether this group of frail elderly is still inhibited about and interested in innovations in the community. The study of Fokkema \& Van Tilburg (2005) has already shown that it was very hard to socially activate elderly people of advanced age. They concluded that the availability of socially rich living environments or joint activities was not enough to encourage these elderly to really enjoy these services (46).

Considering the limited use of social services, it is not very likely that these services have a distinct contribution to make towards de-institutionalization. On the contrary, elderly people reported fewer feelings of loneliness and more perceived autonomy after one year. These positive changes cannot be related to an increased use of services, but could be reason enough to postpone institutionalization. In general, less is known about the effect of communitybased services on the probability of institutionalization (12). Impallomeni \& Starr (1995) conclude that community care complements other forms of residential care for frail elderly rather than being the sole option (47). One exception must be made with regard to care management as part of communitybased care. Care management refers to the process of assessing need and coordination services. The main aim of care management is to improve the linkage and referral between health and social services within the framework of community-based long-term care. These services have proven to be effective, and contributed to the de-institutionalization and well-being of communitydwelling elderly (27). Duke (2005) proved that service was cost-effective while improving quality of life (15). However, this service was not available in both regions, but seems to be an interesting innovation to improve community-based long-term care for elderly people.

\section{REFERENCES}

1. Cheek J, Ballantyne A, Byers L, Quan J. From retiremant village to residential aged care: what older people and their families say. Health and Social Care in the Community 2006, 15:8-17.

2. Van Bilsen PMA, Hamers JPH, Groot W, Spreeuwenberg C. Demand of elderly people for residential care: an exploratory study. BMC Health Services Research 2006, 6(39).

3. Young J, Turnock S. Community care waiting lists and older people. BMJ 2001, 322:254.

4. Gallagher LP, Truglio-Londrigan M. Community support. Older Adults'perceptions. Clinical Nursing Research 2004, 13:3-23. 


\section{Chapter 6}

5. Splann Krothe J. Giving voice to Elderly People: Community-Based Long Term Care. Public Health Nursing 1997, 14:217-226.

6. Nolan M, Dellasega C. 'I really feel I've let him down': supporting family carers during longterm care placement for elders. Journal of Advanced Nursing 2000, 31:759-767.

7. Gibler KM, Moschis GP, Lee E. Planning to move to retirement housing. Financial Services Review 1998, 7:291-300.

8. Rosenberg M, Everitt J. Planning for aging populations: inside or outside the walls. Progress in Planning 2001, 56:199-168.

9. Rauner MS, Vissers JMH. OR applied to health services: Planning for the future with scarce resources. European Journal of Operational Research 2003, 150:1-2.

10. Cox CB. Community Care for an Aging Society. Issues, Policies and Services. New York: Springer Publishing Company, Inc. 2005.

11. Greene VL. Do Community-Based Long-Term-Care Services Reduce Nursing Home Use? A Transition Probability Analysis. The Journal of Human Resources 1993, 28:297-317.

12. Gaugler JE, Kane RL, Kane RA, Newcomer R. Early Community-Based Service Utilization and Its Effects on Institutionalization in Dementia Caregiving. The Gerontologist 2005, 45:177185.

13. Borgenicht K, Carty E, Feigenbaum LZ. Community Resources for Frail Older Patients. The Western Journal of Medicine 1997, 167:291-294.

14. Plochg T, Klazinga S. Community-based integrated care: myth or must? International Journal for Quality in Health Care 2002, 14:91-101.

15. Duke C. The frail elderly community-based case management project. Geriatric Nursing 2005, 26:122-127.

16. Boyle G. Facilitating choice and control for older people in long-term care. Health and Social Care in the Community 2004, 12:212-220.

17. Goins RT, Hobbs G. Distribution and Utilization of Home- and Community-Based LongTerm Care Services for the Elderly in North Carolina. Journal of Aging and Social Policy 2001, 12:23-42.

18. Johnson RJ, Wolinsky FD. Use of community-based long-term care services by older adults. Journal of Aging and Health 1996, 8:512-537.

19. Wallace $S$. The no-care zone: Availability, accessibility, and acceptability in community based long term care. The Gerontologist 1990, 30:254-262.

20. Moyer A, Coristine M, Jamault M, Roberge G, O'Hagan M. Identifying older people in need using action research. Journal of Clinical Nursing 1999, 8:103-111.

21. Yeatts D, Crow T, Folts E. Service use among low-income minority elderly: Strategies for overcoming barriers. The Gerontologist 1992, 32:24-31.

22. Walker M, Orrell M, Manela M, Livingston G, Katona C. Do health and use of services differ in residents of sheltered accommodation? A pilot study. International Journal of Geriatric Psychiatry 1998, 13:617-624.

23. Moon A, Lubben JE, Villa V. Awareness and utilization of community long-term care services by elderly Korean and Non-Hispanic White Americans. The Gerontologist 1998, 38:309-316.

24. Schoenberg N, Coward R. Residential differences in attitudes about barriers to using 
community-based services among older elderly. The Journal of Rural Health 1998, 14:295-304.

25. Leutz WN, Capitman J, Green CA. A limited entitlement for community care: how members use services. Journal of Aging \& Social Policy 2001, 12:43-64.

26. Challis D, Darton R, Hughes J, Stewart K, Weiner K. Intensive care management at home: an alternative to institutional care? Age and Ageing 2001, 30:409-413.

27. Shapiro A, Taylor M. Effects of a community-based early intervention program on the subjective well-being, institutionalization. and mortality of low-income elders. The Gerontologist 2002, 42(3).

28. Ross-van Dorp C. Extramuralisering in relatie tot de modernisering van de $A W B Z$ en boumproblematiek intramurale zorg. Transformation of institutions into independent dwellings in relation to the Exceptional Medical Expenses Act and intramural care. The Hague: Ministry of Health, Welfare and Sport (VWS) 2003.

29. Ross-van Dorp C. Subsidieregeling diensten bij wonen met zorg (Government-sponsored financial contribution community-cased care). The Hague, Ministry of Health, Welfare and Sport (VWS) 2003.

30. Ministry of Health, Welfare and Sport. Zorgindicatiebesluit; Besluit van 2 oktober 1997, houdende regels met betrekking tot werkterrein, de samenstelling en werkwijze van indicatieorganen (Care Needs Assessment Decree; White Paper of October, 2, 1997, regulating the activities, formation and mode of operation of Regional Needs Assessment Agencies). Staatsblad van het Koningrijke der Nederlanden 1997, Sdu 447.

31. National Council for Public Health. Indicatiestelling en zorg op maat: advies van de Nationale Raad voor de Volksgezondheid en het College voor Ziekenhuisvoorzieningen Needs assessments and customised care: recommendations by the National Council for Public Health and the Council for Hospital Facilities). Zoetermeer: National Council for Public Health (RVZ) 1994.

32. Centrale Commissie Mensgebonden Onderzoek (Committee on Research involving Human Subjects), www.ccmo.nl 2007.

33. Van Bilsen P, Hamers J, Groot W, Spreeuwenberg C. Sheltered housing compared to independent living in the community. Scandinavian Journal of Caring Sciences. Accepted for publication.

34. Van der Zee KI, Sanderman R. Het meten van de algemene gezondheidstoestand met de RAND-36: een handleiding (Measuring bealth with the RAND-36: a manual). Groningen: Noordelijk Centrum voor Gezondheidsvraagstukken (NCG) 1993.

35. Moorer P, Suurmeijer PBM, Foets M, Molenaar IW. Psychometric properties of the RAND36 among three chronic diseases (multiple sclerosis, rheumatic diseases and COPD) in the Netherlands. Quality of Life Research 2001, 10:637-645.

36. Diener E, Emmons RA, Larsen RJ, Griffin S. The satisfaction with life scale. Journal of Personality Assessment 1985, 49:71-75.

37. De Jong-Gierveld J, Kamphuis F. The development of a Rasch-type loneliness scale. Applied Psychological Measurement 1985, 9:289-299.

38. De Jong-Gierveld J, Van Tilburg T. Manual of the Loneliness Scale. Retrieved February 9, 2004 from http://home.scw.vu.nl/ tilburg/manual loneliness scale 1999.html; 1999.

39. Kempen GIJM, Miedema I, Ormel J, Molenaar W. The assessment of disability with the Groningen Activity Restriction Scale. Conceptual framework and psychometric properties. 
Chapter 6

Social Science \& Medicine 1996, 43:1601-1610.

40. Kempen GIJM, Doeglas DM, Suurmeijer TPBM. Het meten van problemen met zelfredzaambeid op verzorgend en buishoudelijk gebied met de Groningen Activiteiten Restrictie Schaal (GARS): een bandleiding (Measuring functional status with regard to personal and domestic care by the Groningen Activity Restriction Scale: a manual). Groningen: Noordelijk Centrum voor Gezondheidsvraagstukken, Rijksuniversiteit Groningen 1993.

41. Van Campen C, Kerkstra A. Kwaliteit van leven van somatische verpleeghuispatiënten. Een begripsverbeldering en overzicht van meetinstrumenten (Quality of life of somatic patients in nursing homes. A detailed definition and an overview of measurement instruments). Utrecht: Netherlands Institute for Health Services Research (NIVEL) 1995.

42. Van Bilsen PMA, Hamers JPH, Groot W, Spreeuwenberg C. Welke zorg vragen ouderen? Een inventarisatie (What care do elderly people ask for? An overview). Maastricht: Universitaire Pers Maastricht 2002.

43. Van Bilsen PMA, Hamers JPH, Groot W, Spreeuwenberg C. Welke zorg vragen ouderen? Een inventarisatie (What care do elderly people ask for? An overview). TSG 2004, 82:221-228.

44. Nunnally JCJ. Psychometric Theory. 2e ed. New York McGraw-Hill 1978.

45. Hamers J, Van Bilsen P. The care of the elderly in nursing settings - are those cared for getting what they need? In: Sousa-Poza A, editor. Proceedings of the 2nd World Ageing and Generations Congress. St. Gallen: World Demographic Association 2006.

46. Fokkema T, Tilburg Tv. Eenzaam en dan? De (on)mogelijkheden van interventies bij ouderen. (Loneliness and then what? The (im)possibilities of interventions by elderly people). Beverwijk: Stichting Sluyterman van Loo 2005.

47. Impallomeni M, Starr J. The changing face of community and institutional care for the elderly. Journal of Public Health Medicine 1995, 17:171-178. 
The use of community-based social services: an evaluation 


\section{GENERAL DISCUSSION}


Chapter 7 


\section{INTRODUCTION}

In this thesis the perceived needs of elderly people for long-term care and support were studied in a variety of ways. Apart from an overview of various needs, the basic need of elderly people to live independently and to be in control as long as possible was contrasted to the actual demand for residential care. Furthermore, the use of social services as part of community-based long-term care was also evaluated. In sum, the following four questions have been answered:

1. What are the perceived needs of elderly people for care and support?

2. Are waiting lists for admission into a home for the elderly an accurate reflection of the perceived need for services of elderly people in later life?

3. To what extent are community-based social services being used by those elderly people at risk of institutionalization who prefer to remain independently in the community?

4. Do elderly people living in sheltered accommodation differ in terms of personal characteristics, functional status, well-being and care and service use, from those living independently in the community, considering the fact that both groups are at risk of institutionalization?

This chapter will begin with a summary of the main conclusions of the studies presented in this thesis. Following this, methodological reflections will be discussed. Finally, the implications for practice and recommendations for future research will be presented.

\section{MAIN CONCLUSIONS}

\section{Perceived needs for care and support vary}

Considering the heterogeneity of the elderly population, as well as the diversity and variability of the perceived deficits, it would appear next to impossible to outline the variation in perceived needs for care and services (Chapter 2). More specifically, the extent to which elderly people perceive deficits in self-care and subsequently try to overcome them strongly depends on their personal wishes, circumstances and capabilities. Nonetheless, these extensive reflections of the elderly were important for arriving at an understanding of their perceived need for services and support within the context of their more basic needs and requisites. For instance, the need for care especially arose when functional or cognitive impairments hinder elderly people to live independent. Still, most elderly wished to remain in their own homes and to be in control of their own lives as long as possible (need for autonomy), even when impairments severely affected their abilities and independence. Care for elderly people should, therefore, entail more than health care alone. Services in the areas of housing, transport and well-being should also be taken into account, as these will enable them to fulfil their basic needs. Besides the need for autonomy, the needs both for social relationships and leisure activities were also frequently mentioned. 
Those elderly people interviewed were quite capable of addressing their needs and preferences even though these perceived needs were usually phrased in terms of existing 'supply-driven' arrangements. Lack of information about health care supply, provision of services and conditions of supply hindered them from making a deliberate choice based on their individual situation and from rethinking the existing supply of services. Nevertheless, critical remarks were noted with regard to the quantity (e.g., waiting lists) and quality of the available supply of care services (e.g., complex regulation, inaccessible public facilities).

These results regarding the perceived needs of elderly people have been made comprehensible and usable for practice and scientific research by combining them in a theoretical model (see also Chapter 3) [1-3]. There are three main assumptions underlying this model (see Figure 1). First, elderly people usually express to their need for care and support (e.g., personal care, adjusted housing, a wheelchair, housekeeping services, transportation, meals-on-wheels) within the context of basic human needs. More specifically, the basic need for social relationships, pleasurable stimulation, security, self-esteem, autonomy and basic care (food) play a significant role in elderly people's lives vis-à-vis their need for care. The need for autonomy is especially of the utmost importance. Elderly people continue to emphasize how important it is for them to live independently outside an intramural setting and to be in control of their own lives, even when impairments severely affect their abilities and independence. Consequently, according to the elderly the perceived need for care has to be defined as everything that is an obstacle to independent living. Furthermore, basic needs are influenced by a range of personal characteristics (e.g., age, gender, cognitive abilities) and changing circumstances (e.g., household composition). The second major assumption concerns the availability of resources such as mobility, self-care agency, informal care, income and a social network for fulfilling their basic needs. Similar diseases do not result in similar needs. The answer lies in the availability of people's resources. Resources are defined as personal circumstances or means, which enable and support elderly people to fulfil their basic needs. As long as people can fulfil their needs by themselves, supported by resources, they will no longer have a perceived need for services. At the point where their needs are no longer fulfilled, however, three possibilities usually occur: 1) they adjust their needs (e.g., acceptance of the mobility problem and its consequences); 2) they seek support to compensate for a deficit (e.g., senior transportation or devices like an electric scooter or wheelchair); or 3) they simply live with these unmet needs. Thus, the actual demand for care is the result of one or more needs unmet due to insufficiencies in available resources; this is the third major assumption. Finally, the process described in this model will be usually influenced by cultural factors.

According to the model presented, the resources of elderly people are paramount in the development of a more demand-driven health care supply. 
Consequently, the development of (new) services should focus on people's resources, rather than their individual needs.

Figure 1 The relations between people's needs, resources and demand for services

Culture

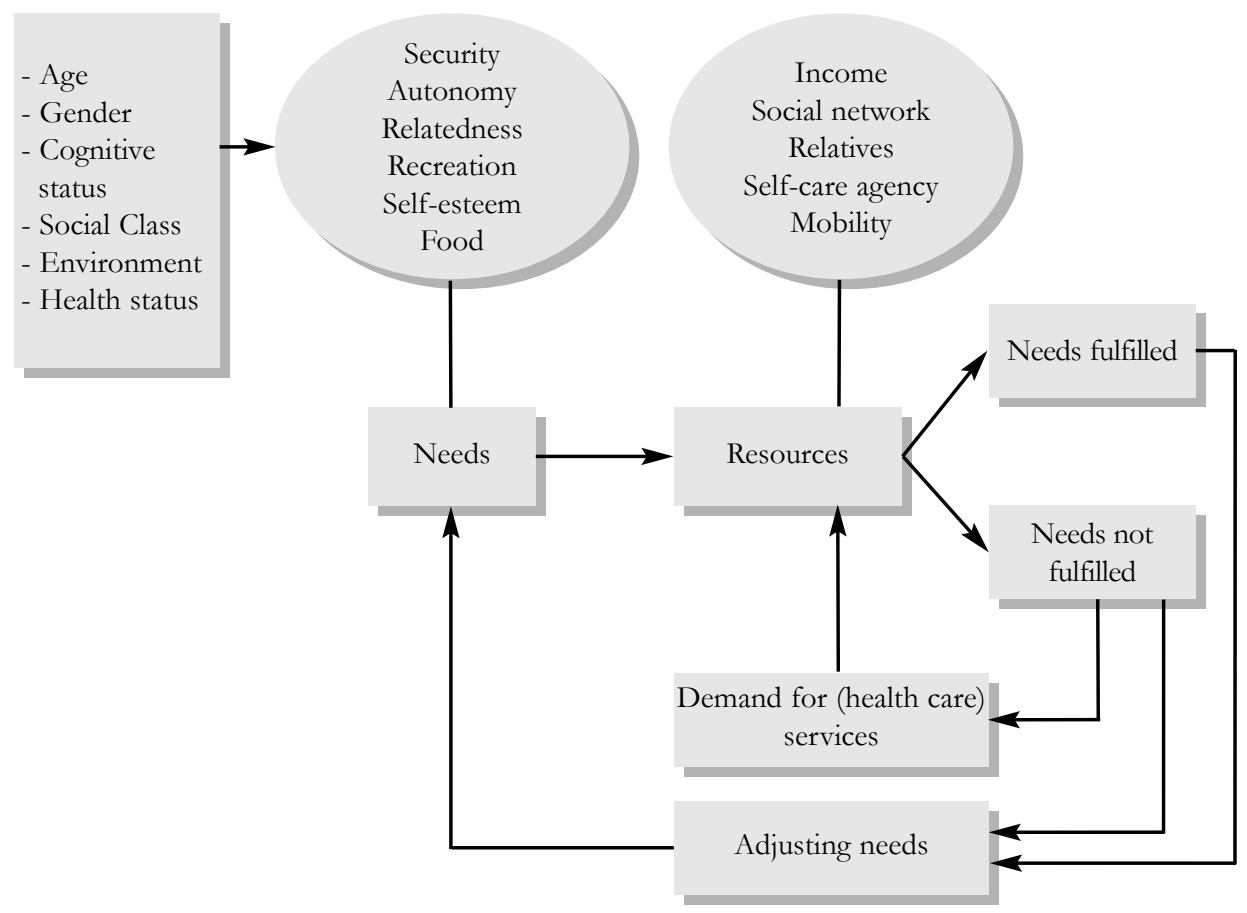

\section{Waiting lists are an inaccurate reflection of perceived need}

The demand for admission to homes for the elderly, which finds expression in extensive waiting lists for this type of care, has proven to be an inadequate measure of the real perceived need for residential care (Chapter 3). Over a third of the elderly people on a waiting list actually have no immediate need for this type of care and will not accept an offer of admission to the home of their first choice. Given their vulnerable health and the current shortages in residential care, they have registered just as a precaution and not because they have a perceived need for residential care. The inability to manage everyday activities and the lack of a social network were associated with elderly people's demand for residential care. More explicitly, the more satisfactory the social network, the less likely the chance that they would accept an offer of admission. In terms of functional status, it was found that the chance of acceptance became higher as 
the physical limitations increased. So resources such as social network play a distinct role in explaining those perceived needs, which may eventually result in a demand for care.

\section{Limited use of community-based social services}

Community-based social services have been set up with the intention of supporting people in their activities of daily living. Although these services have become readily available, the results show that the use of these communitybased social services was very moderate to poor, even after twelve months (Chapters 4 and 6). Obviously there is a discrepancy between the supply of community-based social services and the perceived need for these services by those elderly people at risk of being institutionalized. With the exception of socio-cultural activities (e.g., sports, games, excursions) and restaurant facilities, the use of buddy projects, telephone circle and personal adviser was limited. This raises questions about the nature of the services offered ('Do elderly people actually want these specific social services?'), the accessibility of the services ('Which barriers could be hindering elderly people from using these services?'), the elderly population 'at risk of institutionalization' ('Is this old and frail population still interested in innovations in the community?') and the ability of these social services to contribute to de-institutionalization ('Do social services have a distinct contribution to make in de-institutionalization?'). These questions could not be answered based on the results, although the comparison between the users and non-users of social services did reveal some factors that could explain the usage of services. These factors were foremost obviously related to the accessibility and approachability of the social services, on the one hand, and the ability of elderly people to use them, on the other. Generally speaking, users of social services perceived fewer (physical) barriers to the use of these social services than do did non-users. More specifically, elderly people living in a sheltered accommodation were more likely to use social services. This can be explained by the fact that social activities were usually organized at communal locations or day care centres linked to sheltered living facilities. Furthermore, compared to elderly people in regular houses, sheltered-living elderly were less inconvenienced by mobility problems. Also, elderly people who received informal care were more likely to participate in social services. The involvement of informal caregivers might actually mean that elderly persons are consequently better informed about these services, and are therefore more motivated and able to access them.

\section{Sheltered accommodations provide added value}

Two comparable groups of frail elderly people in two housing situations differed in terms of perceived quality of life, autonomy and feelings of insecurity; those respondents living in sheltered housing evaluated their quality of life more favourably and experienced greater autonomy and fewer feelings of insecurity 
than did respondents living independently in the community (Chapter 5). Sheltered-living elderly were also more likely to receive nursing care and participated more in social activities. By contrast, respondents living independently in the community received more hours of housekeeping assistance and made more use of day care centres. Altogether, sheltered housing combines the favourable attributes of residential care (sheltered accommodation, care facilities and personal alert system) and living independently in the community (privacy and autonomy).

\section{METHODOLOGICAL REFLECTIONS}

The studies conducted can be characterized as exploratory, using cross-sectional designs. No definite conclusions regarding causal relationships (predictors) can be made. However, this was not the aim of the studies. Their general aim was to explore the perceived needs of the elderly for care and support, which would result in a better understanding of these needs, their heterogeneity and variability. The in-depth interviews with elderly people especially contributed to a deepening of the understanding of how basic needs relate to perceived needs for care and support, as well as underscoring the importance of resources. This has resulted in a model that can be seen as a gain, considering the fact that most needs assessments are quite a-theoretical at the very time when policy makers and programme planners increasingly recognize the value of theory [4].

Overall, the response rate was moderate. Although the demographic characteristics of the samples are comparable to those of similar populations [5, 6] and nation-wide demographics [7]), the possibility of selection bias cannot be ruled out. Given the reasons for non-response it is quite possible that the respondents interviewed are part of the relatively healthier segment of all eligible for inclusion. This might have led to an overestimation of the share of those who were on a waiting list due to a sense of precaution and of those using community-based social services. That is, it could be expected that the 'healthier' elderly, less hindered by their functional-impairment status, were those more likely to use social services and still be less focused on residential care. However, all elderly selected were entitled to residential care and 24-hour care-on-demand (i.e., were at risk of institutionalization) according to the needs assessment procedure conducted by the assessment agencies created specifically to determine a person's need for care objectively and to prescribe adequate care in terms of type, nature and amount [8, 9].

Also the dropout analysis (Chapter 6) provides some reason to think that those elderly who participated twice do represent the 'healthier' segment. Those respondents who dropped out during the study, more often received informal care and perceived a lower quality of life. The dropouts tended to be older and more functionally impaired than those respondents who were interviewed twice. These results imply that the study included comparatively younger respondents, who perceived a better quality of life. However, it is not very likely that the 
dropout has biased the results, because both groups were similar with regard to their social service use at baseline.

With the exception of the self-developed measures of 'autonomy', 'insecurity' and the mobility scale, we used measurements that have been proven to have satisfying psychometric properties [10-17]. In addition, according to the developers these measures were also appropriate for use in face-to-face interviews. The two measures assessing 'autonomy' and 'feelings of security' were added because 'independence', 'being in control' and 'feelings of security' proved to be major issues for the general well-being of the elderly [1, 18, 19], in addition to serving as motivating factors that consistently emerged as a reason to move to sheltered housing [20]. Unfortunately, no valid and reliable measurements were available at that time [18]. The autonomy and security items were phrased on the basis of results of earlier research about elderly people's basic and care needs [1], and they appear on the surface to have face validity. Both measures, however, should be studied in more detail to assess 'autonomy' and 'feelings of insecurity' in a reproducible and valid fashion. The results of these underlying studies might well be seen as a useful starting point. The items measuring 'accessibility of house and nearby area' (mobility) were derived from the official assessment protocol of the assessment agency and have proven to be internally consistent (reliability). However, more research on psychometric properties is needed. Finally, it would seem advisable to use a more easily manageable measure for quality of life. Although the VAS is the essence of simplicity [21], quite a few respondents perceived difficulties in using the VAS mainly because of visual problems or lack of understanding.

\section{POLICY IMPLICATIONS AND DIRECTIONS FOR FURTHER RESEARCH}

The general aim of this thesis was to explore the perceived needs of elderly people for care and support in order to contribute to more demand-oriented care and support for elderly people. This raises the question of whether the findings yielded valuable information about the perceived needs of elderly people in order to be helpful in practice. The answer is ambiguous. On the one hand, the results did deepen our understanding of the perceived needs for care and support of elderly people. The theoretical model that was developed does make the results more comprehensible and usable for practice and research. On the other hand, a lot of new questions were raised when relating the perceived need for independent living to the actual demand for residential care and the use of community-based social services. These new questions could be a sufficient reason to instigate new scientific research so as to gain more insight into the needs, as well as the demand for and the use of services by elderly people.

Considering both sides, the way in which the results have added value to practice will be described below, together with recommendations and challenges for future research. 


\section{Resources}

According to the model presented, the resources of elderly people are the key in the development of a more demand-oriented health care supply. This has the following logical implication for health care policy: The development of (new) services should focus on people's resources, rather than their individual needs. For example, providers of (health care) services should primarily support older people's resources such as their mobility, social network or self-care agency. By supporting - for instance - the mobility of the elderly, elderly people can attend their preferred activities themselves or continue to visit significant others. Consequently, elderly people are enabled to fulfil their needs for recreation and relatedness. Other examples would be offering more support to informal caregivers or volunteers (e.g., respite care, emotional care, information). Informal caregivers are an important 'resource' of elderly people, especially when they still live independently in the community. Support directed at informal caregivers might decrease the risk that informal caregivers get overburdened. Subsequently, this might decrease the risk of admission of elderly people to an intramural setting.

It should, however be emphasized, that this model is a subject for further research. Both the operationalizations of people's characteristics, needs, and resources, and the predicted relations between the key concepts must be further investigated.

\section{Autonomy}

An important outcome of this study is that the need for autonomy was especially predominant. Autonomy concerns the wish of elderly people even when they were at risk of institutionalization to live independently and to be in control of their own daily lives. Marmot (2004) has even stressed that autonomy and the opportunity you have for full social engagement and participation are crucial to health, well-being and longevity [19]. Blane et al. (2002) have agreed on this; They have conceptualized quality of life as consisting of the satisfaction of needs in four areas, including the needs for control and independence [22]. However, a reliable and valid instrument to measure the autonomy of elderly people was not available at that time. So, based on the findings, it should be recommended to develop such a measuring instrument in order to examine in a standardized way the fulfilment of this basic need for independence and control, as well as to examine the quality of life in old age.

\section{Housing}

Dutch policy concerning elderly people in society encourages independent living for elderly people in the community and pays attention to related issues such as the physical features of housing and environment that affect the ability of elderly people with limitations to live independently, safely and comfortable [23]. The results have shown that those elderly people living in sheltered 
accommodations indeed have a higher perceived autonomy, sense of security and quality of life. So, from a purely objective point of view, this policy concerning the elderly is in line with the perceived need of elderly people for independent living and the importance of adequate housing. However, figures in the Netherlands also show that there is a substantial shortage in elderly housing [23]. This should be resolved in a society faced with increasing numbers of frail elderly people with disabilities. New strategies and approaches need to be developed to increase housing options, including home modifications, linkage between housing and services, as well as various forms of supportive housing.

The question of whether sheltered accommodations could postpone admission to homes for the elderly could not be answered. So it remains unclear whether the advent of sheltered housing is leading to a decrease in waiting lists for residential care. Given the political dimension of this issue, the appropriateness of the present admission procedures for homes for the elderly will an important topic for future research.

\section{Waiting lists}

Generally, waiting lists represent a crisis, first and foremost for patients who must wait in pain, uncertainty and anxiety [24]. While examining the actual demand for residential care in relation to the perceived need for this type of care by the elderly, several issues occurred. First, quite a few elderly people only registered for residential care as a precaution in case they needed admission to an institution at some future date. This should be prevented so that elderly people who really want and need residential care are able to receive the care they want and are entitled to. Consequently, the assessment agencies responsible for objective assessment and allocation of care should be aware of this phenomenon. It is recommended that explicit attention be paid to the underlying motives behind registering for this type of care. Second, it maybe worthwhile to repeat this needs assessment periodically, even for those already on a waiting list. Needs fluctuate over time, due to illness, recovery or other circumstances. Elderly people often opt to register after grave health problems. Some of them recover and then no longer perceive the need for residential care. Most of them never take any steps to have their names removed from the waiting lists. Third, $19 \%$ of the elderly we approached was actually no longer waiting due to a failing registration and double counting. In order to have a reliable overview of waiting lists, this problem requires ongoing attention.

\section{Social services}

The community-based social services we evaluated were set up to enable elderly people to remain at home independently. Thus, if we consider 'social services' on their own merits, they clearly fit into a demand-oriented approach in which care supply is guided by elderly people's wants and basic need to age in the community, outside the walls of an institution. However, the use of these 
services ranged from limited to poor. This raises questions about the desirability of these specific services, as well as their accessibility and effectiveness. In order to answer these questions, first, a well-thought-out approach to rethinking the current supply of community-based social services and potential barriers to them is to be recommended. The model 'The relations between health care needs, resources and demands' [1-3] could be a helpful tool. Second, existing knowledge about those barriers and facilitators that influence older adults' utilization of social services should be used in order to explore possible barriers related to the social services under study [25-31]. In sum, not only should elderly people be aware of the services offered, they should also have a perceived need for these services and, at finally, be truly able to use them. Third, the effect of these social services on the probability of institutionalization was not studied. As a result, no information has become available about the contribution of these services towards de-institutionalization. Therefore, future research on this topic does provide added value.

\section{REFERENCES}

1. Van Bilsen PMA, Hamers JPH, Groot W, Spreeuwenberg C. Welke zorg vragen ouderen? Een inventarisatie (What care do elderly people ask for? An overview). Maastricht: Universitaire Pers Maastricht 2002.

2. Hamers JPH, Van Bilsen PMA: The care of the elderly in nursing settings - are those cared for getting what they need? In: Proceedings of the 2nd World Ageing and Generations Congress. Edited by Sousa-Poza A. St. Gallen: World Demographic Association; 2006.

3. Van Bilsen PMA, Hamers JPH, Groot W, Spreeuwenberg C. Demand of elderly people for residential care: an exploratory study. BMC Health Services Research 2006, 6(39).

4. Calsyn RJ, Roades LA, Klinkenberg WD. Using theory to design needs assessments studies of the elderly. Evaluation and Program Planning 1998, 2:277-286.

5. Caris-Verhallen WMCM, Kerksta A. Continuity of care for patients on a waiting list for institutional long-term care. Health and Social Care in the Community 2001, 9:1-9.

6. Van Eijk LM, Miedema I. Ouderen op de wachtlijst nader bekeken. Een onderzoek onder ouderen op de wachtlijst voor een verzorgingshuis in Oost-Groningen (A closer look at elderly people on a waiting list for residential care in East Groningen). Groningen: Provinciaal Ontwikkelingsinstituut Zorg en Welzijn (POZW) 2001.

7. De Klerk MMY (ed.). Rapportage ouderen 2001. Veranderingen in de leefsituatie (Report elderly people 2001. Changes in social situation). The Haque: Social and Cultural Planning Office of the Netherlands (SCP) 2001.

8. National Council for Public Health. Indicatiestelling en zorg op maat: advies van de Nationale Raad voor de Volksgezondheid en het College voor Ziekenhuisvoorzieningen (Needs assessments and customized care: recommendations by the National Council for Public Health and the Council for Hospital Facilities). Zoetermeer: National Council for Public Health (RVZ) 1994.

9. Ministry of Health, Welfare and Sport. Zorgindicatiebesluit; Besluit van 2 oktober 1997, houdende regels met betrekking tot werkterrein, de samenstelling en werkwijze van indicatieorganen (Care Needs Assessment Decree; White Paper of October 2, 1997, 
regulating the activities, formation and mode of operation of Regional Needs Assessment Agencies). Staatsblad van het Koningrijk der Nederlanden 1997, Sdu 447.

10. Van der Zee KI, Sanderman R. Het meten van de algemene gezondheidstoestand met de RAND-36: een handleiding (Measuring health with the RAND-36: a manual). Groningen: Noordelijk Centrum voor Gezondheidsvraagstukken (NCG) 1993.

11. Moorer P, Suurmeijer PBM, Foets M, Molenaar IW. Psychometric properties of the RAND36 among three chronic diseases (multiple sclerosis, rheumatic diseases and COPD) in the Netherlands. Quality of Life Research 2001, 10:637-645.

12. Diener E, Emmons RA, Larsen RJ, Griffin S. The satisfaction with life scale. Journal of Personality Assessment 1985, 49:71-75.

13. De Jong-Gierveld J, Kamphuis F. The development of a Rasch-type loneliness scale. Applied Psychological Measurement 1985, 9:289-299.

14. De Jong-Gierveld J, Van Tilburg T. Manual of the Loneliness Scale. Retrieved from http//home.scw.vu.nl/ tilburg/manual_loneliness_scale_1999.html.

15. Kempen GIJM, Miedema I, Ormel J, Molenaar W. The assessment of disability with the Groningen Activity Restriction Scale. Conceptual framework and psychometric properties. Social Science \& Medicine 1996, 43:1601-1610.

16. Evers GCM. Appraisal of self-care agency A.S.A-scale. Maastricht: Rijksuniversiteit Limburg 1989.

17. Brouns G, Evers GCM, Smeets H, Isenberg M, Philipsen H. Appraisal of self-care agency scale. Maastricht 1988.

18. Van Campen C, Kerkstra A. Kwaliteit van leven van somatische verpleegbuispatiënten. Een begripsverbeldering en overzicht van meetinstrumenten (Quality of life of somatic patients in nursing homes. A detailed definition and an overview of measurement instruments). Utrecht: NIVEL 1995.

19. Marmot M. The status syndrome. How social standing affects our health and longevity. New York: Henry Holt and Company 2004.

20. Kingston P, Bernard M, Biggs S, Nettleton H. Assessing the health impact of age-specific housing. Health and Social Care in the Community 2001, 9:228-234.

21. Streiner DL, Norman GR. Health measurement scales. A practical guide to their developement and use. New York: Oxford University Press 2003.

22. Blane D, Wiggins R, Higgs P, Hyde M. Inequalities in quality of life in early old age. Sheffield: Growing Old Programme, University of Sheffield 2002.

23. Ministry of Health, Welfare and Sport. Ouderenbeleid in het perspectief van de vergrijzing (Elderly policy in the context of a greying population). The Haque: Ministry of Health, Welfare and Sport (VWS) 2005.

24. Maarse H. The politics of waiting lists in Dutch health care. Eurobealth 2002/2003, 8:27-29.

25. Gallagher LP, Truglio-Londrigan M. Community support. Older Adults' perceptions. Clinical Nursing Research 2004, 13(1):3-23.

26. Johnson RJ, Wolinsky FD. Use of community-based long-term care services by older adults. Journal of Aging and Health 1996, 8:512-537.

27. Moyer A, Coristine M, Jamault M, Roberge G, O'Hagan M. Identifying older people in need using action research. Journal of Clinical Nursing 1999, 8:103-111.

28. Walker M, Orrell M, Manela M, Livingston G, Katona C. Do health and use of services differ 
in residents of sheltered accommodation? A pilot study. International Journal of Geriatric Psychiatry 1998, 13:617-624.

29. Wallace $\mathrm{S}$. The no-care zone: Availability, accessibility, and acceptability in community based long term care. The Gerontologist 1990, 30:254-262.

30. Yeatts D, Crow T, Folts E. Service use among low-income minority elderly: Strategies for overcoming barriers. The Gerontologist 1992, 32:24-31.

31. Young J, Turnock S: Community care waiting lists and older people. BMJ 2001, 322:254. 
SUMMARY

SAMENVATTING

DANKWOORD

CURRICULUM VITAE 
Chapter 8 


\section{SUMMARY}

Demographic and epidemiological changes have transformed the worlds' health care needs, making long-term care for the frail elderly a major policy issue, particularly in developed countries. Good-quality care and access, whitin a context of sustainable systems, is not the only requirement. Aspects like housing, participation in society, sense of purposefulness, social contacts, income, as well as a safe living environment are all essential for elderly people to maintain a balance between living with an increasing need for care and support, in addition to a good quality of life.

Furthermore, persistent cost-effectiveness and quality concerns have stimulated the interest of policy makers concerned with long-term health care solutions, and here general concepts of free-market thinking, consumerism, managed care, demand-orientation, freedom of choice and quality of care improvements have become of paramount significance. These 'demand-driven' approaches aim to build towards a more responsive and effective integrated-care system in combination with a consumer-directed approach so as to maximise the independence and autonomy of disabled elderly people. Consequently, policy makers and caregivers puzzle over the question of how to develop and reorganize the health care system so that it takes the needs of clients into account.

In order to contribute to the development of more demand-oriented care for elderly people, three studies were conducted. The general aim of theses studies was to explore the perceived needs of elderly people for care and support. Therefore, elderly people, and especially those who were at risk of institutionalization, were asked what their needs were in terms of support encompassing the areas of long-term care, social services and housing. Apart from an overview of various needs, the basic need of elderly people to remain living independently in their homes, and to be in control of their own lives for as long as possible was contrasted to the actual demand for residential care. Furthermore, the use of social services as part of community-based long-term care was evaluated. The question was whether elderly people have a perceived need for these services and actually use them. Finally, the importance of sheltered housing for those elderly people at risk of institutionalization was studied as an alternative to ageing in regular housing.

The research questions posed in this thesis were therefore, fourfold:

1. What are the perceived needs of elderly people for care and support?

2. Are waiting lists for admission into a home for the elderly an accurate reflection of the perceived need for services for elderly people in later life?

3. To what extent are community-based social services being used by those elderly people at risk of institutionalization who prefer to remain living independently in the community?

4. Do elderly people living in sheltered accommodation differ in terms of personal characteristics, functional status, well-being, care and service use, from those living in the community independently, considering the fact that both groups are at risk of institutionalization? 
Chapter 1 comprises an introduction to the research subject. Several concepts used in this dissertation are explained here in greater detail such as demand orientation, demand-driven, service needs, demand and use, clients' perspective and being at risk of institutionalization. Also, the general aim of the thesis and research questions are presented at this point. This chapter ends with an outline of the entire thesis.

Chapter 2 gives an overview of the perceived needs of elderly people with regard to health care and support. Based on a literature review and in-depth interviews with a heterogeneous group of elderly people living at home or in a nursing home, it is concluded that the needs of the elderly for care go beyond health care alone and include needs regarding housing, transport and well-being, as well. In addition, it is shown that their needs are dictated by basic human needs such as the need for autonomy and the need for relationships with significant others. In the end, the elderly did not ask for any care supply or special services that which were not already available. Nevertheless, they did comment on the present-day quality and quantity of the services offered. A model was developed in order to translate the listed needs into a comprehensive framework which takes into account the heterogeneity of the elderly population, as well as the diversity and variability of the perceived deficits. This model attempts to explain the relationship between needs, resources and demand for (health care) services.

Chapter 3 presents the results of a study that focused on the demand of elderly people for residential care and determinants (elderly people's personal characteristics, needs and resources) that are associated with this demand. Furthermore, the accuracy of the waiting list for homes for the elderly, as a reflection of the perceived need for residential care, is discussed here. In general, the results show that not everybody who asked for admission into a home for the elderly (demand) actually perceived a need for this type of care, since 35\% of the elderly on a waiting list did not actually experience an immediate demand for residential care and stated that they would not accept an offer of admission. The importance of elderly people's resources such as social networks and the ability to manage everyday activities in relation to the demand for care, became apparent. These findings contribute to understanding the significance of waiting lists for residential care, in addition to emphasizing the importance of a social network and functional status in order to continue to live independently at home.

Chapter 4 shows the results of a study examining the use of communitybased social services by elderly people at risk of institutionalization, but who prefer to stay at home. Two hundred and ninety-two elderly people out of the 334 elderly people at risk, specifically indicated that they would prefer to stay at home rather than being admitted to a home for the elderly if community-based care and services were available. However, the actual use of the social services 
proved to be moderate according to the respondents and even poor according to the formal registration of the caregivers. Only three services (socio-cultural activities, restaurant facilities and individual counselling) were used frequently. The other six services (group counselling by social worker, personal adviser, home library service, telephone circle, buddy project, administrative assistance) were used by less than 15\% of the elderly according to the answers of the respondents. According to the registration of the caregivers, three services were not used at all (group counselling by social worker, home library service and administrative assistance). Elderly people who lived in a sheltered environment, or were supported by informal caregivers or visit day care, had a significantly higher probability of using community-based social services. From this it was concluded that more attention needs to be given to the nature and accessibility of social services.

Chapter 5 focuses on the comparison of independently living elderly people at risk of institutionalization, living in two types of housing situation: sheltered accommodation and living independently in the community. Although both groups were similar in demographic details and functional status, those in sheltered accommodations had a higher perceived autonomy, a higher sense of security and a higher quality of life. In addition, those in sheltered accommodations participated more frequently in socio-cultural activities and restaurant facilities. Elderly people living in regular houses needed more hours of housekeeping assistance and visited day care facilities more frequently. Based on these findings, it was concluded that sheltered housing seemed to provide added value and, therefore, should be an integral part of long-term policy.

Chapter 6 reports a study with a longitudinal design (measurements at two points in time). The purpose of this study was to explore the use of communitybased social services by elderly people at risk of institutionalization, but who preferred to remain at home. In total 134 elderly people participated at baseline and at twelve-month follow-up. Despite the offer of additional social services, the use of these services by those elderly at risk of institutionalization did not increase over a one-year period. Overall, the use of social services remained moderate. This raises questions about the perceived need for these services, the possible barriers to them, the population itself of 'elderly people at risk of institutionalization' and the ability of these social services to contribute to deinstitutionalization. Although functional status, perceived well-being and quality of life did not change, these elderly people reported more autonomy and fewer feelings of loneliness after one year. These positive changes cannot be related to an increase in use of services.

Chapter 7 summarizes the main findings of the studies presented in this thesis. In addition, some methodological reflections are discussed here. The chapter then ends with the implications of the thesis both for both practice and future research. 
Chapter 8 


\section{SAMENVATTING}

Door demografische en epidemiologische veranderingen staat, met name in de ontwikkelde landen, de zorg voor ouderen hoog op de politieke agenda. Het gaat hierbij niet alleen om kwalitatief goede en toegankelijke zorg in een duurzaam gezondheidszorgsysteem. Ook aspecten als wonen, maatschappelijke participatie, een betekenisvol bestaan, sociale contacten, inkomen en een veilige leefomgeving zijn van essentieel belang voor ouderen om een hoge kwaliteit van leven te behouden in een periode waarin zij geconfronteerd worden met toenemende beperkingen en een groeiende behoefte aan zorg en ondersteuning.

Door aanhoudende kosteneffectiviteitproblemen en zorgen omtrent de kwaliteit van zorg zijn beleidsmakers genoodzaakt na te denken over lange termijn oplossingen. Dit heeft geleid tot de introductie van concepten zoals marktwerking, consumptiementaliteit, ketenzorg, vraaggerichtheid, keuzevrijheid en kwaliteit van zorg in de gezondheidszorg. Deze zogenaamde 'vraaggestuurde' benaderingen hebben tot doel bij te dragen aan een integraal zorgsysteem dat niet alleen effectief maar ook cliëntgericht is. Hiermee wordt bedoeld dat de zorg voor ouderen gericht moet zijn op zowel het ondersteunen van ouderen in hun behoefte om zo lang mogelijk zelfstandig te wonen als de wens om zoveel mogelijk de regie over hun eigen leven te behouden. De vraag die vervolgens rijst is hoe het beste invulling gegeven kan worden aan een gezondheidszorgsysteem dat uitgaat van de behoeften van ouderen.

Ten einde een bijdrage te leveren aan de ontwikkeling en invulling van een meer vraaggerichte zorg voor ouderen, zijn drie onderzoeken uitgevoerd. Het algemene doel van deze onderzoeken was het verkennen van de ervaren behoeften van ouderen aan zorg en ondersteuning. Om dit doel te bereiken is allereerst aan ouderen gevraagd wat hun behoeften aan zorg en ondersteuning zijn op het gebied van zorg, welzijn en wonen. Vervolgens is de basale behoefte van ouderen om zo lang mogelijk zelfstandig te wonen en zelf te bepalen hoe het dagelijkse leven er uit ziet, afgezet tegen de vraag naar verzorgingshuiszorg zoals deze tot uitdrukking komt in de wachtlijsten voor opname in een verzorgingshuis. Ten derde, is het gebruik van welzijnsvoorzieningen door ouderen die nog zelfstandig in de wijk wonen geëvalueerd. De vraag was of deze ouderen behoefte hebben aan dit soort welzijnsvoorzieningen en of deze behoefte tot uitdrukking komt in het gebruik van deze voorzieningen. Tenslotte is het belang van beschermd wonen voor ouderen die in aanmerking komen voor een opname in het verzorgingshuis bestudeerd als alternatief voor zelfstandig wonen in de wijk.

De volgende vier vragen staan dientengevolge in dit proefschrift centraal:

1. Wat zijn de ervaren behoeften van ouderen aan zorg en ondersteuning?

2. Zijn wachtlijsten voor opname in een verzorgingshuis een accurate afspiegeling van de ervaren behoefte aan zorg van ouderen op latere leeftijd? 
3. In welke mate worden welzijndiensten gebruikt door ouderen die in aanmerking komen voor opname in een verzorgingshuis maar aangeven liever zelfstandig in de wijk te blijven wonen?

4. Is er verschil tussen ouderen die beschermd wonen en ouderen die nog zelfstandig in de wijk wonen wat betreft hun persoonlijke kenmerken, zelfredzaamheid, welbevinden, zorg- en welzijnsgebruik gegeven het feit dat beide groepen in aanmerking komen voor opname in een verzorginghuis op basis van hun beperkingen?

Hoofdstuk 1 bevat een algemene introductie over het onderwerp van onderzoeken. Verschillende concepten en begrippen (vraaggerichtheid, vraaggestuurd, zorgbehoeften, zorgvraag en zorggebruik, cliëntenperspectief en 'ouderen die in aanmerking komen voor verzorgingshuiszorg') die in dit proefschrift centraal staan worden gedefinieerd en nader verklaard. In de introductie wordt ook het uiteindelijke doel van onderzoek en de bijbehorende onderzoeksvragen gepresenteerd. Hoofdstuk 1 sluit af met een beknopt overzicht van de inhoud en opbouw van het proefschrift.

Hoofdstuk 2 geeft een overzicht van de ervaren behoeften van ouderen aan zorg en ondersteuning. Op basis van literatuurstudie en diepte- interviews met een heterogene groep ouderen die óf nog thuis wonen óf inmiddels zijn opgenomen in een verpleeghuis, wordt geconcludeerd dat de behoeften van ouderen verder strekken dan de gezondheidszorg alleen. Ouderen wensen een totaalpakket van voorzieningen en diensten op het gebied van gezondheidszorg, wonen, vervoer en welzijn. Duidelijk wordt dat deze behoeften aan zorg en ondersteuning voortvloeien uit meer universeel menselijke behoeften zoals de behoefte aan autonomie en sociale relaties met belangrijke anderen. Opvallend is dat de geïnterviewde ouderen niet aangeven bepaalde zorgvoorzieningen of diensten te missen. Wel plaatsen zij kanttekeningen bij de huidige kwaliteit en kwantiteit van het zorg- en dienstenaanbod. Op basis van de onderzoeksbevindingen is een model ontwikkeld om de geïnventariseerde behoeften te vertalen in een begrijpelijk kader dat tegelijkertijd ruimte biedt aan de heterogeniteit binnen de doelgroep ouderen en de variabiliteit van ervaren behoeften en tekorten. Het model geeft inzicht in de relatie tussen behoeften, bronnen en de vraag naar (zorg)voorzieningen.

Hoofdstuk 3 presenteert de resultaten van het onderzoek naar de vraag van ouderen naar verzorgingshuiszorg en determinanten (persoonlijke kenmerken, behoeften en bronnen) die gerelateerd zijn aan deze vraag. Nagegaan is in hoeverre wachtlijsten voor opname in een verzorgingshuis een betrouwbare afspiegeling zijn van de ervaren behoefte van ouderen aan verzorgingshuiszorg. De resultaten tonen aan dat niet iedereen die vraagt om opgenomen te worden in een verzorgingshuis, ook daadwerkelijk een behoefte heeft aan deze zorg. Zo zegt 35\% van de ouderen die op een wachtlijst voor opname staat, deze zorg niet te willen en een aanbod voor opname te weigeren. Duidelijk wordt dat 'bronnen' 
zoals een sociaal netwerk en zelfredzaamheid een belangrijke rol spelen in relatie tot de vraag voor verzorgingshuiszorg. De resultaten van dit onderzoek dragen bij aan een realistisch beeld van de wachtlijstproblematiek voor verzorgingshuiszorg en benadrukken het belang van een sociaal netwerk en zelfredzaamheid in het voorkomen van opname in een verzorgingshuis.

Hoofdstuk 4 beschrijft de resultaten van het onderzoek naar het gebruik van welzijnsdiensten door ouderen die nog zelfstandig thuis wonen maar op grond van hun beperkingen wel in aanmerking komen voor opname in een verzorgingshuis. Van de in totaal 334 ouderen met een 'verblijfsindicatie', geven 292 ouderen aan liever zelfstandig thuis te willen blijven wonen als zorg en welzijnsdiensten in de wijk beschikbaar zijn. Het daadwerkelijk gebruik van deze welzijnsdiensten is echter matig volgens de ouderen zelf, en zelfs beperkt volgens de formele registratie van de zorgaanbieders. Slechts drie voorzieningen (sociaal culturele voorzieningen, sociaal restaurant en individuele ondersteuning) worden regelmatig gebruikt volgens de ouderen. De overige zes voorzieningen (groepsmaatschappelijk werk, ouderenadviseur, bibliotheek aan huis, telefooncirkel, maatjesproject, klapper project) worden door minder dan 15\% van de ouderen afgenomen. Vergeleken met de antwoorden van de ouderen, maken de ouderen volgens de registratie van de zorgaanbieders nog minder gebruik van de diensten. Drie diensten worden zelfs helemaal niet gebruikt (groepsmaatschappelijk werk, bibliotheek aan huis, klapperproject). Naarmate de ouderen beschermd wonen, ondersteuning krijgen van mantelzorgers en de dagopvang bezoeken, is de kans groter dat ze gebruik maken van welzijnsvoorzieningen. Op basis van de bevindingen wordt geconcludeerd dat de aard van het aanbod en de toegankelijkheid van deze welzijnsvoorzieningen voor ouderen meer aandacht verdient.

Hoofdstuk 5 betreft een vergelijkende studie waarbij ouderen die op grond van hun beperkingen in aanmerking komen voor opname in een verzorgingshuis in twee verschillende woonsituaties zijn bestudeerd: ouderen die beschermd wonen en ouderen die zelfstandig in de wijk wonen in een reguliere woning. Ondanks het feit dat beide groepen vergelijkbaar zijn wat betreft demografische kenmerken en zelfredzaamheid, ervaren de ouderen die beschermd wonen meer autonomie, meer veiligheid en een hogere kwaliteit van leven. Bovendien blijkt dat ouderen die beschermd wonen vaker deelnemen aan sociaal-culturele activiteiten en sociale restaurants bezoeken. Ouderen die onafhankelijk in de wijk wonen maken daarentegen meer gebruik van huishoudelijke ondersteuning en bezoeken de dagopvang vaker. Geconcludeerd wordt dat een beschermde woonomgeving voor ouderen een toegevoegde waarde heeft en deel moet uitmaken van het totale zorgbeleid voor ouderen.

Hoofdstuk 6 presenteert de resultaten van een onderzoek met een longitudinale opzet (metingen op twee momenten in de tijd). Het doel van dit onderzoek was inzicht krijgen in het gebruik van welzijnsvoorzieningen door ouderen in de loop van één jaar, waarbij opgemerkt dient te worden dat deze 
ouderen allen in aanmerking komen voor verzorgingshuiszorg maar de voorkeur geven aan zelfstandig wonen in de wijk. In totaal zijn 134 ouderen zowel tijdens de eerste meting als tweede meting (12 maanden later) geïnterviewd. Ondanks de extra welzijnsvoorzieningen die zijn opgezet voor deze zelfstandig wonende ouderen, is het gebruik van deze voorzieningen niet toegenomen gedurende de onderzoeksperiode. In het algemeen kan gesteld worden dat het gebruik van deze voorzieningen nog steeds matig is. De vraag die rijst naar aanleiding van deze bevindingen is hoe het komt dat deze ouderen weinig gebruik maken van dit aanbod van diensten? Kanttekeningen worden geplaatst bij de ervaren behoefte van ouderen - en in het bijzonder deze specifieke doelgroep - aan dit soort voorzieningen, de toegankelijkheid van deze diensten en de bijdrage van deze voorzieningen aan het voorkomen van een verzorgingshuisopname. Ondanks het feit dat de mate van zelfredzaamheid, het welbevinden en de kwaliteit van leven niet zijn veranderd in de loop van het jaar, ervaren de ouderen na een jaar wel meer autonomie en minder gevoelens van eenzaamheid. Deze positieve veranderingen kunnen echter niet in relatie worden gebracht met het gebruik van welzijnsdiensten.

Hoofdstuk 7 geeft een samenvatting van de belangrijkste resultaten van de onderzoeken die in dit proefschrift beschreven zijn. Verder worden in dit hoofdstuk methodologische kanttekeningen geplaatst bij de diverse onderzoeken. Afgesloten wordt met aanbevelingen voor de praktijk en toekomstig onderzoek. 


\section{DANKWOORD}

Ik wil beginnen met het hartelijk bedanken van alle ouderen die ik de afgelopen jaren in het kader van dit onderzoek heb geïnterviewd. Een onderzoek als dit is niet mogelijk zonder hun medewerking. De gesprekken vormen de basis van dit proefschrift. Ik ben hen, maar ook hun partners, kinderen en vrienden die vaak aanwezig waren bij de interviews, erkentelijk voor de tijd die ik in hun persoonlijke omgeving, heb mogen doorbrengen. De openhartigheid waarmee gesproken werd over de persoonlijke levensfeer heb ik zeer gewaardeerd.

De uitvoering van dit onderzoek was niet mogelijk geweest zonder de medewerking van de zorgaanbieders in Limburg (in het bijzonder de Westelijke Mijnstreek), de zorgaanbieders in Zeeland, de zorgkantoren in beide regio's en de Provincie Limburg. Ook aan hen mijn dank. De bijeenkomsten van de klankbordgroepen tijdens de opzet en uitvoeringsfase van het onderzoek hebben zeer bijgedragen aan de kwaliteit van het onderzoek en de uiteindelijke verslaglegging hiervan.

Zorgverzekeraar CZ Actief in Gezondheid, Zorgverzekeraar VGZ, Provincie Limburg/Provinciale Raad van de Volksgezondheid en het Ministerie van Volksgezondheid, Welzijn en Sport hebben dit onderzoek in financieel opzicht mogelijk gemaakt. Ik ben hen hier zeer erkentelijk voor.

Een speciaal woord van dank gaat uit naar mijn promotor Prof. dr. Jan Hamers. Ik heb niet alleen zijn begeleiding, opbouwende kritiek en voorspoedige samenwerking, maar vooral zijn betrokkenheid en positivisme in tijden van tegenslag zeer gewaardeerd. Jan, heel hartelijk bedankt.

Ook ben ik mijn twee andere promotoren Prof. dr. Wim Groot en Prof. dr. Cor Spreeuwenberg dank verschuldigd. Zowel tijdens de opzet en uitvoering van de diverse onderzoeken, als bij het schrijven van de diverse wetenschappelijke artikelen en dit proefschrift, heb ik frequent gebruik gemaakt van hun wetenschappelijke expertise, kennis en kritische reflecties. Wim en Cor, bedankt voor de prettige samenwerking.

Vanaf dag één zijn de diverse onderzoeken kritisch beschouwd door de begeleidingscommissie 'Zorgbehoefte, sector Ouderen'. Ik wil mijn waardering uitspreken aan alle leden die in de loop der tijd lid zijn geweest van deze commissie en hen hartelijk bedanken voor hun inspanningen en levendige discussies tijdens de bijeenkomsten.

Het zelf afnemen van alle interviews bleek een onhaalbare zaak. Het was fijn dat ik hulp bij het interviewen heb gekregen van een aantal studenten die bereid waren mee te interviewen. Drs. Anne Don wil ik hierbij expliciet bedanken voor haar bijdrage aan de uitvoering van het onderzoek in Zeeland. 
Mijn collega's van de vakgroep Verplegingswetenschap wil ik bedanken voor de opbouwende kritiek tijdens refereerbijeenkomsten, de mogelijkheid om 'even binnen te vallen met vragen' en de steun, collegialiteit en vriendschap die ik de afgelopen jaren heb ervaren.

Een speciaal woord van dank is voor mijn paranimfen Anna Huizing en Astrid Lamers. Astrid bedankt dat je me toentertijd attendeerde op de uitgelopen sollicitatieprocedure bij ZW/VW. Anna, een fijnere collega, kamergenoot en inmiddels vriendin had ik niet kunnen wensen. Heel erg bedankt.

Ik ben mijn ouders, Jos, Isa, Yannick, Jasper, Joris, broers, schoonzussen, overige familie en vrienden dankbaar voor hun steun en interesse in mijn promotietraject als wel de ontspanning, gezelligheid en relativering buiten werktijden. Ik ben blij dat jullie in mijn leven zijn. 


\section{CURRICULUM VITAE}

\section{Personal}

Name

Pascalle Marie Antoinette van Bilsen

Date of birth

November 13, 1966

Place of birth

Spaubeek, the Netherlands

\section{Education}

1994-1995

Psychometric Theory. Construction of tests.

Faculty of Department of Psychology and Education.

VU University, Amsterdam

1990-1991

Mass Communication and Public Relations

Faculty of Social and Behavioural Sciences

Utrecht University, Utrecht

1986-1991

Master programme Health Sciences, specialisation of

Health Promotion and Health Education

1979-1986

Maastricht University, Maastricht

Secondary school (VWO)

Henric van Veldeke College, Maastricht

\section{Work}

11.2007- present

$06.2001-10.2007$

10.1997-05.2001

03.1997-03.1998

11.1995- 03.1997

08.1992- 10.1995

$08.1991-12.1992$
Post-doc position at Maastricht University, Maastricht PhD Programme, Faculty of Health Sciences

Department Health Care Studies/Section Nursing science Maastricht University, Maastricht

Manager at the Diagnostic Centre Amsterdam (DCA), Amsterdam

Researcher on 'Side effects and withdrawal symptoms of SSRI drugs'. Research centre Good Clinical Practice (GCP), Rotterdam

Researcher on the subject 'Nursing assistants behaviour with elderly people suffering from dementia'. Netherlands Institute for Health Services Research (NIVEL), Utrecht

Researcher on two projects (Spinal opioid analgesia at home and care coordination for MS patients). Research Centre 1e-2e level VU University Medical Centre Amsterdam, Amsterdam

Researcher on the effectiveness of sex education provided to adolescents. International Health Foundation, Brussels 
